Sheila Fernandes Pimenta e Oliveira

Vânia de Fátima Martino

Genaro Alvarenga Fonseca (org.)

\title{
Sustentabilidade e Meio Ambiente: perspectivas da educação ambiental
}

Coleção Educação e Educandos
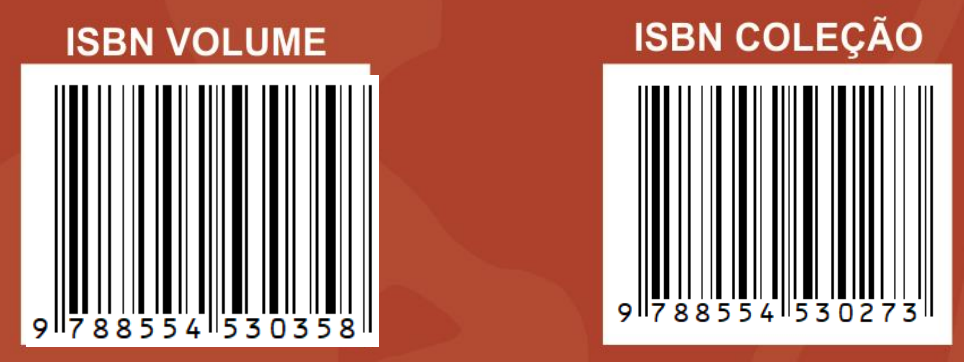

\author{
DOI \\ $10.29327 / 513200$
}


SUSTENTABILIDADE E MEIO AMBIENTE: perspectivas da educação ambiental 
Sheila Fernandes Pimenta e Oliveira

Vânia de Fátima Martino

Genaro Alvarenga Fonseca

Tatiana Noronha de Souza (org.)

\section{SUSTENTABILIDADE E MEIO AMBIENTE: PERSPECTIVAS DA EDUCAÇÃO AMBIENTAL}

ISBN 978-85-5453-035-8

FRANCA

Uni-FACEF/UNESP

2019

Comissão Científica 


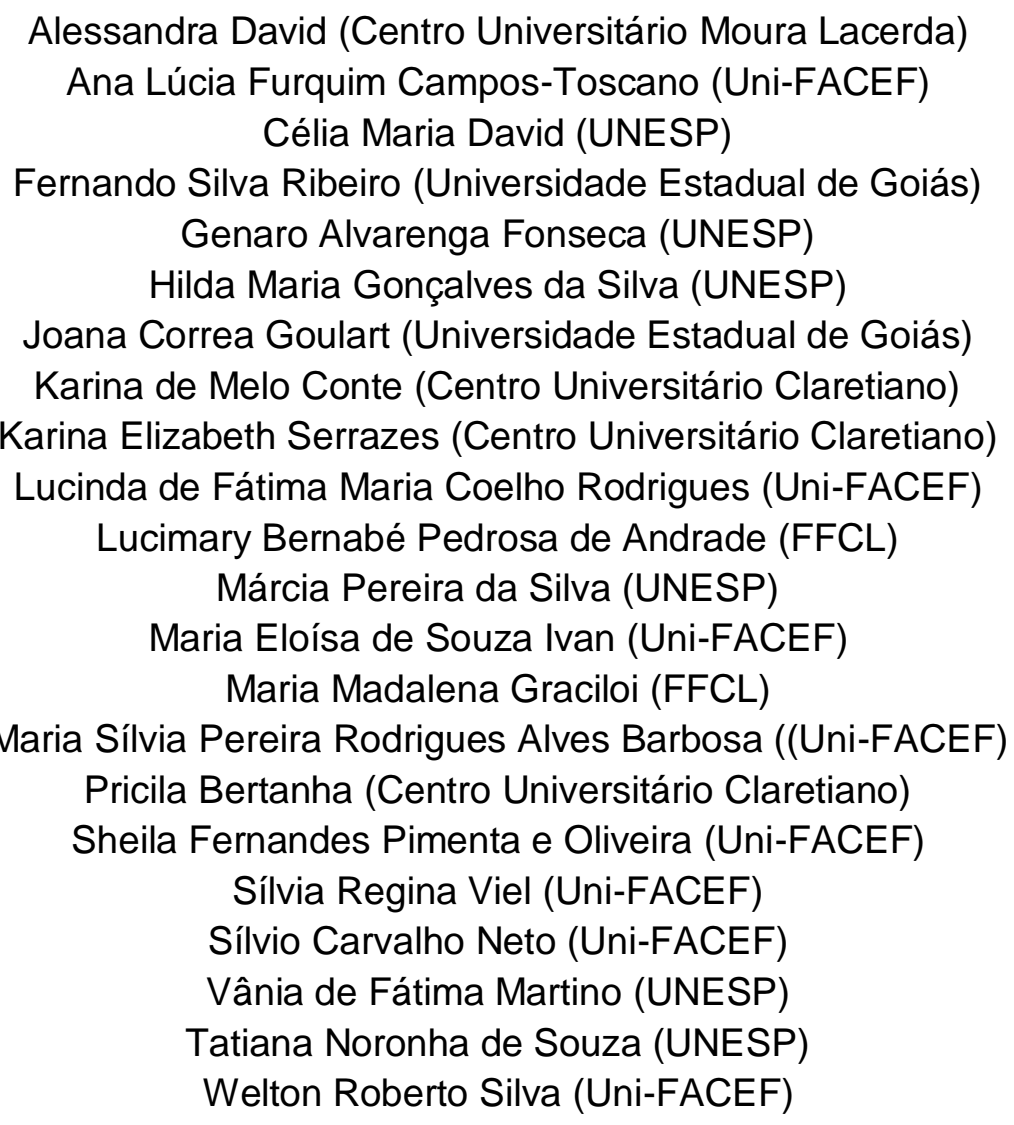

\section{Conselho Editorial}

Ana Cláudia da Silva (UnB)

Antônio Carlos Petean (UFU)

Daniela Melaré Vieira Barros - Universidade Aberta / Portugal

Danilo Seithi Kato (UFTM)

Genaro Alvarenga Fonseca (UNESP)

Sheila Fernandes Pimenta e Oliveira ((Uni-FACEF)

Sílvio Carvalho Neto (Uni-FACEF)

Teise de Oliveira Guaranha Garcia - FFCLRP / USP

Vânia de Fátima Martino (UNESP) 
(C) 2019 dos autores

Direitos de publicação Uni-FACEF

www.unifacef.com.br

Coleção: Educação e Educandos, v.9. 


\begin{tabular}{|c|c|c|c|}
\hline \multirow[t]{4}{*}{ O51s } & \multicolumn{3}{|c|}{$\begin{array}{l}\text { Oliveira, Sheila Fernandes Pimenta e (Org.) } \\
\text { Sustentabilidade e meio ambiente: perspectivas da educação ambiental. } \\
\text { / Sheila Fernandes Pimenta e Oliveira; Vânia de Fátima Martino; Genaro } \\
\text { Alvarenga Fonseca (Org.). - Franca: Uni-FACEF; Unesp/Franca; } 2019 . \\
\text { (Coleção: Educação e educandos, v.9). } \\
\text { 94p.; il. }\end{array}$} \\
\hline & \multicolumn{3}{|l|}{$\begin{array}{l}\text { ISBN Coleção: 978-85-5453-027-3 } \\
\text { ISBN Volume: 978-85-5453-035-8 } \\
\text { DOI 10.29327/513200 }\end{array}$} \\
\hline & $\begin{array}{l}\text { 1.Educação - Pesquisa. } \\
\text { 3.Sustentabilidade e meio ambiente. }\end{array}$ & $\begin{array}{l}\text { 2. Educação } \\
\text { I.T. }\end{array}$ & ambiental. \\
\hline & & & CDD 370 \\
\hline
\end{tabular}

TODOS OS DIREITOS RESERVADOS.

É proibida a reprodução total ou parcial, de qualquer forma ou por qualquer meio. A violação dos direitos de autor (lei no. 9.610/98) é crime estabelecido pelo artigo 184 do código Penal. Todo o conteúdo apresentado neste livro é de responsabilidade exclusiva de seus autores.

Editora Uni-FACEF Centro Universitário Municipal de Franca

Associada à ABEC - Associação Brasileira de Editores Científicos 


\section{PREFÁCIO}

Desde a primeira conferência internacional sobre Educação Ambiental, que ocorreu em 1977 em Tibilisi, na antiga União Soviética, considerada o marco inicial da Educação Ambiental, diferentes países uniram esforços para definir estratégias, objetivos e princípios orientadores para a realização de um sistema de Educação Ambiental eficaz em escala mundial.

De lá para cá, muitas outras conferências foram realizadas no sentido de fazer com que a preocupação com esta temática se refletisse nas políticas públicas governamentais.

Na conferência Rio 92, quinze anos após a primeira tentativa de reflexão sobre este tema, elaborou-se um documento, cuja proposição foi a criação de um código ético planetário, em que a preocupação com o meio Ambiente e a sustentabilidade direcionasse as políticas públicas. Este documento ficou conhecido como "Carta da Terra", cujas proposições centrais se apoiavam na realização de ações sustentáveis, visando à preservação de planeta, assim como propostas para uma sociedade planetária mais justa e igualitária.

Todas estas ações possibilitaram que, no início do século $X X I$, o tema Educação ambiental estivesse em pauta nas principais discussões tanto no meio social, como político e acadêmico.

Este volume "Sustentabilidade e Meio Ambiente: perspectivas da Educação Ambiental" apresenta-se como parte da coleção "Educação e Educandos", organizado no VII Simpósio de Educação e IV Encontro Internacional de Políticas Públicas em Educação. Este evento tornou possível a realização desta obra que é fruto da parceria das instituições UNESP e Uni-FACEF, cuja finalidade é discutir e repensar caminhos para os profissionais envolvidos com a educação.

Neste volume, o estudo do presente tema objetiva primeiramente a discussão dos principais problemas ligados à questão do desenvolvimento social e sua conexão com o Meio Ambiente. Entende-se que "meio ambiente" constitui-se o espaço, onde recursos humanos e naturais possam se desenvolver de forma harmônica e sustentável, assim tal temática adquire uma intrincada complexidade. Neste contexto, deve-se também considerar a importância da educação no sentido de estabelecer um novo enfoque, em que se possa constituir um paradigma contemporâneo sobre a questão ambiental, enxergando não somente a natureza como um ecossistema natural, mas, sobretudo como um espaço de relações socioambientais sendo constantemente construído e reformulado.

Os textos que compõe este volume são frutos de estudos e reflexões que envolvem esta temática.

Prof. Dr. Genaro Alvarenga Fonseca Docente da Faculdade de Ciências Humanas e Sociais Unesp/Franca 


\section{SUMÁRIO}

ASSESSORIA VERDE, UM PROJETO DE MEDIAÇÃO POR UMA OCUPAÇÃO DO ESPAÇO MAIS VÍVIDA, COLORIDA E SABOROSA ................... EDUCAÇÃO AMBIENTAL NA RECUPERAÇÃO ECOLÓGICA DA LAGOA DO CAPIM NO RIO SANTA BÁRBARA-SP

EDUCAÇÃO AMBIENTAL X VIOLÊNCIA ESCOLAR: Uma experiência em uma cidade do interior de São Paulo

EDUCAÇÃO AMBIENTAL: Pesquisa-ação realizada no Programa Projovem Adolescente de Franca (SP)

EDUCAÇÃO PARA A SUSTENTABILIDADE: Uma proposta de ações para a conscientização da população sobre processo de coleta de lixo reciclável

ENSINANDO PARA A SUSTENTABILIDADE ATRAVÉS DE HORTAS ESCOLARES

POLÍTICA PÚBLICA EXITOSA DE EDUCAÇÃO AMBIENTAL: Programa Educacional de Difusão do Pau-Brasil em Franca-SP 82 ÍNDICE 


\title{
ASSESSORIA VERDE, UM PROJETO DE MEDIAÇÃO POR UMA OCUPAÇÃO DO ESPAÇO MAIS VÍVIDA, COLORIDA E SABOROSA
}

\author{
TAMBASCO, Aline de Oliveira \\ Graduanda em Relações Internacionais- UNESP \\ alinetambasco96@gmail.com \\ OLIVEIRA, Vinicius Moraes Machado de \\ Mestrando em História e Cultura Social - UNESP \\ vini.moliveira08@gmail.com \\ FONSECA, Genaro Alvarenga \\ Doutor em Educação Escolar - UNESP \\ gafonseca@uol.com.br
}

\section{INTRODUÇÃO}

Nos últimos tempos, a temática ambiental tem ganhado, cada dia mais, destaque no campo midiático. Provavelmente a concepção de que há estabelecida, na atualidade, uma crise ambiental esteja sendo cada vez mais discutida e redimensionada por todas as áreas do pensamento. Desta forma, compreendemos que o resgate da atividade intelectual voltada à Educação e a Educação Ambiental, têm se mostrado de extrema importância para a atuação e debates acerca do meio ambiente em seu caráter mais amplo.

É de conhecimento geral que uma das maiores responsabilidades que uma universidade de ensino superior gratuito tem para/com a sociedade é de retribuir seus investimentos através de projetos sociais. Sendo assim, o GEIA, Grupo de Incentivo à Educação Ambiental da Universidade Estadual Paulista (UNESP), Campus Franca, fundamenta suas atividades na troca de saberes e vivências em prol de uma formação socioambiental mais consciente para o futuro, que favoreça a sociedade como um todo, mas tendo em vista a deficiência por parte do governo na criação e mantenimento da qualidade ambiental para as classes menos favorecidas.

Então, uma das atividades que o grupo realiza temos a Assessoria Verde, um projeto de mediação ecológica entre o indivíduo e a natureza a partir do auxílio no cuidado das áreas verdes presentes na vida da sociedade da cidade de Franca, seja em sua casa, seu local de trabalho ou áreas públicas de seu cotidiano.

Todavia, mais além de levar informações práticas sobre o plantio de mudas e os cuidados que devemos ter com a natureza, através do contato iniciado pela Assessoria Verde buscamos sensibilizar os cidadãos sobre o impacto causado por eles no mundo devido a simples práticas diárias. Podendo a partir disso 
reorientar os hábitos destas pessoas rumo à um novo tipo de cidadania, ecologicamente orientada.

Desde 2015, ano de criação de nosso grupo de extensão podemos verificar empiricamente que a conscientização acerca da natureza e de sua preservação é mais efetiva quando associada à atividades práticas horizontais e acessíveis. Assim, iremos neste artigo demonstrar algumas experiências práticas que podem exemplificar melhor a construção dessa nova mentalidade mais ecologicamente orientada, uma com crianças do ensino público municipal e outra com estudantes universitários.

\section{CONTEXTUALIZANDO A EDUCAÇÃO AMBIENTAL}

Os debates e pesquisas acerca da Educação Ambiental (EA) no país obtiveram uma expansão significativas na década de 1990. Autores como Taglieber e Galliazzi, afirmam que esta guinada se deu graças a visibilidade que a temática ganhou com a Rio 92, entre outros eventos que tiveram papel importante na discussão e apresentação de novas ideias a respeito da EA como a I Conferência Nacional de Educação Ambiental (ocorrida em Brasília em 1997) (VIOLA, 1997).

Além disso, vale ressaltar que a maior parte dos cursos de pósgraduação na área hoje existentes, foram implantados na mesma década. Certamente que seria incompleto não pontuar que esta movimentação no território brasileiro faz parte de uma mobilização internacional iniciada, provavelmente, com a publicação dos Relatórios Meadows - intitulados como Os Limites do Crescimento (MEADOWS et al, 1973) - na década de 70, que colocava a Educação em destaque na estratégia contra os crescentes problemas ambientais que o mundo vinha enfrentando. Seguindo esta linha, a Educação Ambiental chega ao Brasil "sem maiores questionamentos, sobretudo quanto aos seus pressupostos teóricos" (MEADOWS et al, 1973).

O ECO 92 sediado no Rio de Janeiro (Rio 92) é considerado um dos mais importantes encontros sobre o meio ambiente humano. Duas décadas após a primeira Conferência Mundial das Nações Unidas sobre o Meio Ambiente Humano, ocorrida em Estocolmo, reuniram-se, na cidade maravilhosa, representantes de 170 países que acabaram por elaborar o tratado da Educação Ambiental para as Sociedades Sustentáveis e Responsabilidade Global. É neste mesmo ano que, a partir dos debates realizados na conferência, o Instituto Brasileiro do Meio Ambiente e dos Recursos Naturais Renováveis (IBAMA) - órgão responsável pela execução da Política Nacional de Meio Ambiente (PNMA) - instituiu os Núcleos de Educação Ambiental em todas as suas superintendências estaduais, a fim de operacionalizar, em dimensões regionais, a gestão ambiental, o que mais tarde culminaria na criação do Ministério do Meio Ambiente. 
Além de todo o trabalho do IBAMA, de acordo com a PNMA, de difusão da temática ambiental por todo o território, é a partir de 1993 que iniciou-se, no âmbito legislativo, um discussão quanto a uma interligação entre os sistemas nacionais referentes ao meio ambiente com os sistemas educacionais. É a partir disto que, em dezembro de 1994, foi criado pela Presidência da República o Programa Nacional de Educação Ambiental (PRONEA), que ficou sob responsabilidade do então Ministério do Meio Ambiente, da Educação e Desporto, dos Recursos Hídricos e da Amazônia Legal, em parceria com os ministérios da Cultura e da Ciência e Tecnologia. O PRONEA, envolveu diversas entidades públicas e privadas em sua execução que previa "três componentes: (a) capacitação de gestores e educadores, (b) desenvolvimento de ações educativas, e (c) desenvolvimento de instrumentos e metodologias." (BRASIL, 2019).

Contudo, o estabelecimento efetivo da Educação Ambiental como tema reconhecidamente essencial se deu, provavelmente, no ano de $1999 \mathrm{com}$ a lei no 9795/99, que em seus primeiros artigos diz o seguinte:

Art. 1ํ Entende-se por educação ambiental os processos por meio dos quais o indivíduo e a coletividade constroem valores sociais, conhecimentos, habilidades, atitudes e competências voltadas para a conservação do meio ambiente, bem de uso comum do povo, essencial à sadia qualidade de vida e sua sustentabilidade. Art. 2 ${ }^{\circ} \mathrm{A}$ educação ambiental é um componente essencial e permanente da educação nacional, devendo estar presente, de forma articulada, em todos os níveis e modalidades do processo educativo, em caráter formal e não-formal. (BRASIL, 1999).

Com a estruturação desta lei, o que é possível notar são as primeiras tentativas de legalmente se desenhar quais os princípios basilares da EA. Em seu quarto artigo a mesma descreve:

São princípios básicos da educação ambiental: I- o enfoque humanista, holístico, democrático e participativo; II - a concepção do meio ambiente em sua totalidade, considerando a interdependência entre o meio natural, o socioeconômico e o cultural, sob o enfoque da sustentabilidade; III - o pluralismo de ideias e concepções pedagógicas, na perspectiva da inter, multi e transdisciplinaridade; IV - a vinculação entre a ética, a educação, o trabalho e as práticas sociais; $\mathrm{V}$ - a garantia de continuidade e permanência do processo educativo; VI - a permanente avaliação crítica do processo educativo; VII - a abordagem articulada das questões ambientais locais, regionais, nacionais e globais; VIII - o reconhecimento e o respeito pluralidade e à diversidade individual e cultural. (IBDEM)

Desta forma, a Educação Ambiental, alinhada com os princípios da Constituição Federal de 1988, deveria respeitar a diferença objetivando alcançar o número máximo de pessoas para uma noção crítica quanto a questão ambiental. Um despertar para uma consciência coletiva quanto os problemas que o Meio Ambiente o qual esta mesma coletividade está inserida. Ou seja, seria responsabilidade do Estado brasileiro educar a sua população para que esta estivesse alinhada com o 
ideal de sustentabilidade e que pudesse educar as próximas gerações para este mesmo direcionamento de preservação ambiental.

Porém, uma vez inserida no universo das ideias pedagógicas aplicadas na história brasileira, a EA assume um caráter individualista e tecnicista, uma vez que a pedagogia tradicional e a tecno-produtivista são as perspectivas pedagógicas que ainda continuam por manter maior influência nas salas de aula do país.

A tarefa de salvar a humanidade de uma hecatombe ambiental proporcionada pela própria ação humana, quando levada pra dentro da sala de aula gerou, em grande parte dos projetos em EA, uma abordagem que alguns autores dentre eles Carvalho, 2004; Pelicioni, 2005; e Ramos, 2006 - chamaram de abordagem naturalista da natureza.

Essa perspectiva, traz em si a noção de distanciamento entre a humanidade "civilizada" e a natureza. Esta última, seria como um todo autônomo que se auto regula, ou seja, o homem aparece como um grande parasita deste ser absoluto que é a natureza. Desta forma, a humanidade se afastou do meio natural durante o processo de evolução pelo qual passou, indo em busca da "civilidade". Assim sendo, esta perspectiva gera uma separação antagônica entre a sociedade e natureza. Portanto, a natureza deveria então ser preservada e distanciada da interferência humana, uma noção nada consciente das relações historicamente estruturadas entre a natureza e a própria sociedade civil.

Assim sendo, é nosso compromisso neste artigo apresentar quais as perspectivas teóricas que subsidiaram e subsidiam as práticas educacionais do GEIA, uma vez que nossa proposta se insere numa perspectiva complexa e popular, que não se limita à perspectiva ecológica da EA. Uma abordagem que pretende ligar a Educação Ambiental às práticas sócio-culturais, objetivando gerar, tanto entre os educandos quanto entre os educadores, uma transformação, mesmo que pequena em direção à uma "subjetividade ecológica" como defende Isabel Cristina Carvalho (2004).

\subsection{Princípios Norteadores}

Em um primeiro momento devemos pontuar aqui que nossa perspectiva agarra-se na ideia de que o ambientalismo como movimento é fruto das construções históricas. Portanto, o mesmo surge dentro de um contexto de crítica ou questionamento do modelo econômico que nos levou a uma crise ambiental, como mencionado anteriormente.

Durante o período de formação do referido grupo de extensão, no início de 2015, certamente a primeira influência - e que ainda mantém grande presença nos estudos do grupo - é o educador brasileiro Paulo Freire. Este não se dedicou, em nenhum de seus escritos, diretamente da EA, entretanto, podemos dizer que são diversas as contribuições do pedagogo em relação a esta Educação Ambiental 
crítica e politizadora, comprometida com a transformação das pessoas. As ideias filosóficas, políticas e pedagógicas do autor, fortalecem a importância de se educar indivíduos para o amor à vida em todas as suas formas.

Esta formação de pessoas críticas e amantes da vida não é uma necessidade descolada de uma realidade experienciada por Paulo Freire. Já na década de 60, o mesmo afirmava, em sua obra "Educação como Prática da Liberdade", que uma das principais tragédias, quiçá a maior, da humanidade é que a mesma, rodeada por mitos e uma intensa publicidade organizada, tem se abstido de sua capacidade de decidir sobre a realidade. Cinquenta anos se passaram desde a constatação do pedagogo e, com o advento da internet e todas suas ramificações, é notória essa permanente abstenção da realidade, mesmo que forçada pelo sistema. Temos nos distanciado gradativamente de nossa capacidade de decisão e transformação. Como o próprio educador nos explica:

\begin{abstract}
as tarefas de seu tempo não são captadas pelo homem simples, mas a ele apresentadas por uma elite que as interpreta e lhas entrega em forma de receita, de prescrição a ser seguida. E quando julga que se salva seguindo prescrições, afoga-se no anonimato nivelador da massificação, sem esperança e sem fé, domesticado e acomodado: já não é sujeito (FREIRE, 1967, p. 51).
\end{abstract}

Freire faz questão em todas as suas grandes obras ressaltar a necessidade de se "ler o mundo mais próximo, identificar potencialidades e desafios, compreendê-los" (CECCON, 2014). Uma educação que seja diretamente contrária a educação da dominação, que nega a subjetividade do indivíduo humano. Essa intensa ligação entre a humanidade e mundo. Este respeito a vida, além de um profundo sentimento de pertença e responsabilidade, podemos dizer que são o cerne do que entendemos por Educação Ambiental. Uma educação que seja crítica que prega o engajamento, a ação em defesa da vida em seu sentido mais amplo.

Nesta esteira, não podemos deixar de mencionar filósofos que apesar de não terem se debruçado sobre a tarefa de trabalhar ideias pedagógicas, tiveram e tem papel importante na construção da prática pedagógica do grupo de extensão. Pensadores como Gilles Deleuze e Félix Guattari e a construção de uma filosofia artística e criativa devem ser mencionados.

Na obra "o que é Filosofia?" os autores destilam críticas à filosofias puramente teóricas e sem vida. Resgatando frequentemente a ideia de que a filosofia não deve ser uma atividade neutra ou passiva, mas sim criadora. Se apropriando de idéias de filósofos como Nietzsche e Spinoza, atacam, no decorrer de toda a obra, as filosofias ocidentais que não potencializam o pensar como ato de criação. Assumir que a filosofia se encaixe apenas em uma tarefa de contemplação, reflexão e comunicação, seria para os dois pensadores uma ideia rasa que não potencializa o pensamento. Afinal, estas atividades seriam apenas ferramentas que, se não reconsideradas, colaboram para um enrijecimento do pensar e que 
corroboraram para a construção de uma história da filosofia que é objetiva e incontestável nos dias de hoje.

Nesse sentido, Deleuze sugere uma postura demoníaca - ou seja negadora dos princípios metafísicos transcendentais que foi construída a filosofia ocidental - no âmbito da filosofia da educação, uma vez que deve-se buscar restabelecer uma conexão entre a educação e o meio ambiente do indivíduo.

$\mathrm{O}$ ato de (re)pensar a EA para a construção da mesma em uma perspectiva nova, combativa e anti-fascista, deve vir acompanhado de uma fuga de ideias pré-determinadas e de conceitos pré-estabelecidos que ditaram ou ditam o que é fazer uma Educação Ambiental no Brasil. Portanto, a mesma deve ser um ato de pensamento, a partir das filosofias da diferença. Por fim, o que nos resta - depois desse breve apanhado teórico que, certamente, serviu como apresentação da perspectiva ativa do GEIA - é adentrarmos o universo da prática da Assessoria Verde.

\section{As experiências da Assessoria Verde}

A Assessoria Verde realizada pelo GEIA, como dito anteriormente, é um projeto de mediação ecológica entre o indivíduo e a natureza através do auxílio prático no manejo de espaços verdes na cidade de Franca, o que significa que nosso grupo vai até casas, apartamentos, escolas, praças, instituições, entre outros, com o intuito de semear, literalmente e figurativamente, a natureza. Na prática o projeto dá assessoria gratuitamente na criação de hortas, cuidados em jardins, plantio de árvores, e na transmissão de técnicas básicas de manejo ecológico ambiental e tudo que envolve o cuidado e carinho com o planeta terra e todos os seres que nele vivem.

Ademais, intrinsecamente, ao mesmo tempo que estamos com a "mão na massa" buscamos ir além dos ensinamentos práticos sobre o manejo ambiental, é nossa intenção também trazer para os cidadãos francanos uma nova orientação intelectual acerca do homem e sua relação com o meio ambiente que o cerca para além de seus muros, sensibilizando-os sobre a importância de ter uma consciência crítica da relação entre nossas práticas sociais diárias, que geralmente são negligenciadas e automatizadas. Nós buscamos, como grupo de extensão de incentivo e educação ambiental, não só trazer informações e ensinar técnicas de manejo ambiental para nossos educandos, o que queremos é formar cidadãos ecologicamente orientados, que tenham consciência de seu impacto na construção de uma sociedade melhor.

Assim, buscamos direcionar nosso plano de manejo para que ele respeite as particularidades individuais dos educandos com quem iremos atuar, para que possamos realizar uma educação que traga para a prática pedagógica maior proximidade da realidade do educando, tornando o aprendizado mais democrático e 
acessível (FREIRE, 1967, p. 53). Então, a cada novo local de realização do projeto de Assessoria Verde nos deparamos com novos contextos e demandas a serem entendidas, estudadas e trabalhadas, para a elaboração de um planejamento didático adequado.

Dentre os diferentes espaços onde o GEIA realizou seu projeto de Assessoria Verde e neste caso somado ao nosso projeto de Educação Ambiental, certamente a Escola Municipal de Educação Básica (EMEB) Frei Lauro de Carvalho Borges, localizada na rua Cândido Carlos Mello no 2860 no bairro Jardim do Eden, área urbana da cidade de Franca, foi o local de maior assiduidade. Ao longo dos cinco anos de existência do grupo, desenvolvemos nossas atividades neste local por aproximadamente dois anos.

Em congruência com nossos ideais educacionais, quando realizamos projetos dentro de escolas sempre atuamos apenas com uma turma durante 0 período de um semestre completo, normalmente duas vezes por mês, dependendo das atividades da escola e da programação dos professores responsáveis pela turma. Pois, para realizar um manejo ambiental ecológico e respeitar os ciclos naturais das plantas e pessoas, se faz necessário um acompanhamento mais duradouro.

Sendo assim, as atividades realizadas na EMEB Frei Lauro de Carvalho Borges ao longo dos últimos anos, foram o $4^{\circ}$ e $5^{\circ}$ ano do ensino fundamental, alternando as turmas entre os semestres. A cada nova turma criamos um conteúdo diferenciado, mas sempre associado com as atividades de manejo na área verde da escola, trazendo a experiência prática, dentro do possível, para as nossas atividades.

O conteúdo programático montado muitas vezes continha os mesmos temas centrais, porém, pudemos perceber que cada turma os vivenciava de uma maneira diferente. Falar sobre educação ambiental não representa nenhum desafio, ao contrário do que se pode pensar, pois a maioria dos temas abordados fazem parte do dia-a-dia comum de toda a população. Assuntos como reciclagem, hortas orgânicas, uso de agrotóxicos, poluição, animais, etc, eram facilmente associados à vida das crianças, nosso trabalho consistia apenas em trazer um novo olhar para eles.

Mas, certamente esses assuntos tornavam-se definitivamente mais divertidos e interessante para os estudantes quando explicados de maneira lúdica, fora da sala de aula, onde o brincar e o aprender se misturam. Usualmente na área verde da escola, plantando ou mexendo nas terras com as crianças que ensinamos e conversamos sobre os tópicos de educação ambiental pensados em nosso programa de ensino.

Todavia, a manutenção e manejo da área verde da escola sempre ocupa o lugar central do trabalho. Chegando em uma nova turma, no início do semestre, depois de conhecer das devidas apresentações com todos os estudantes, 
contamos um pouco sobre nós; o GEIA; e a UNESP. Depois disso, contamos nossa intenção de trazer mais cores e sabores para o dia-a-dia das crianças, isso se eles se comprometerem a ajudar nessa missão, por sorte a taxa de aceitação da nossa ideia até hoje sempre foi de $100 \%$. A partir daí, toda a sala passa a protagonizar nosso projeto, pensamos juntos desde quais espécies de plantas devem ser dispostas na horta até como podemos utilizá-las na culinária. Na foto (Figura 1), temos o registro feito pela professora com a turma do $4^{\circ}$ ano da EMEB Frei Lauro, onde podemos ver as primeiras mudas colocadas na horta.

Figura 1 - Assessoria verde realizada na EMEB Frei Lauro de Carvalho Borges

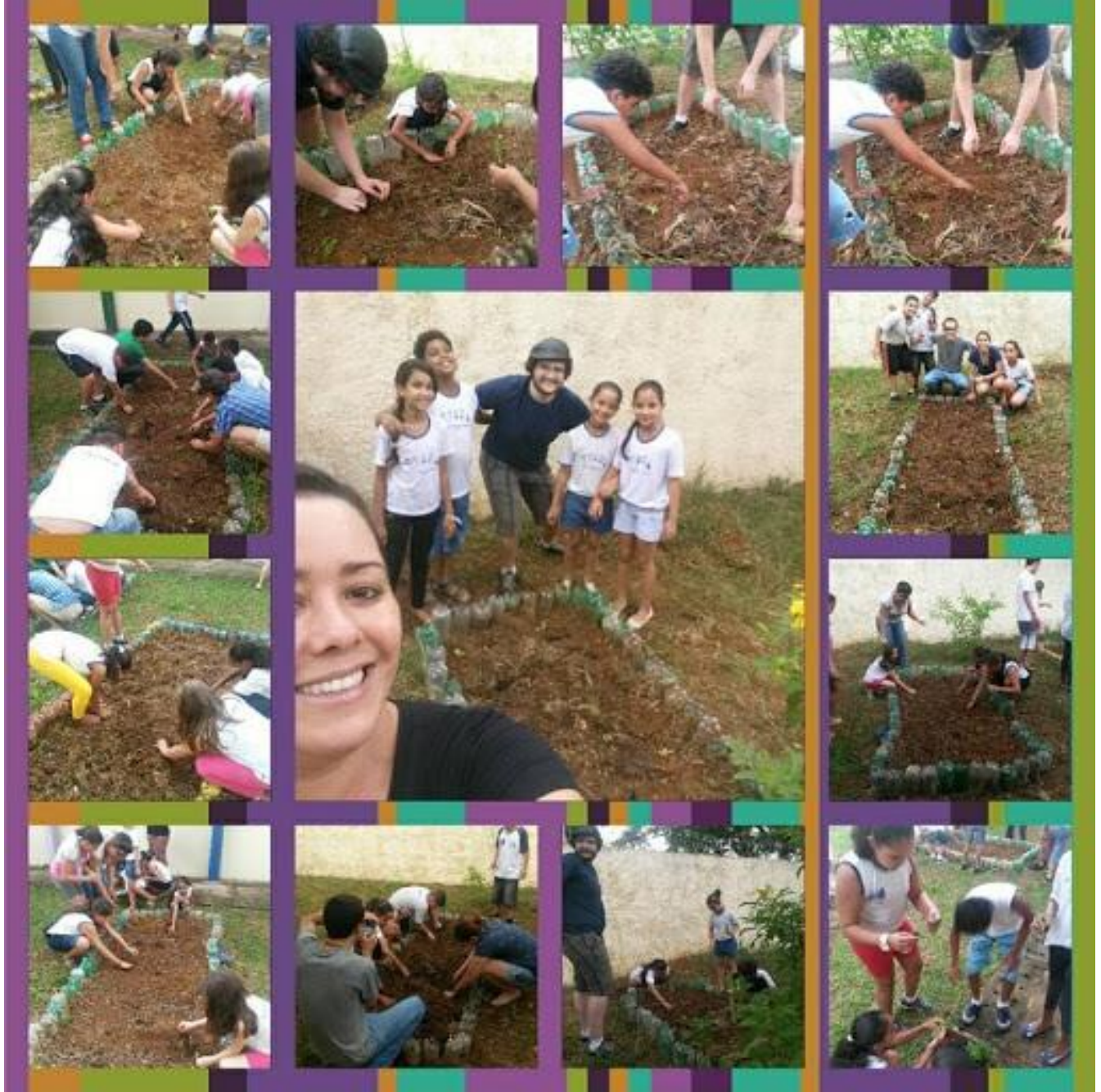

Fonte: Adaptado do autor. (2015)

Outro local frequente de realização da Assessoria Verde são em residências, tanto de estudantes quanto de cidadãos francanos. O contato com os estudantes se faz, usualmente, pela relação do grupo e seus membros dentro do campus universitário, ao realizar atividades e eventos no campus e também pelas relações sociais. Já o aproximamento com os moradores da cidade de Franca ou outras instituições da região geralmente ocorre através das redes sociais do grupo e 
pelas parcerias já feitas com ONG's e grupos independentes que também atuam com a temática ambiental.

As construções modernas, sempre contam com canteiros, jardins ou áreas verdes, entretanto, na grande maioria das vezes eles exercem uma função meramente estética. Essas áreas são preenchidas apenas por plantas ornamentais que não possuem nenhum fim prático para os residentes e que geralmente não são nativas da região, também não trazendo nenhum fim prático para o equilíbrio da fauna e flora regionais.

$\mathrm{Na}$ foto (figura 3) estamos assessorando uma república de estudantes da UNESP localizada no bairro Nova Franca, que se localiza nas proximidades do campus da Universidade e é majoritariamente residencial. Ao estabelecer contato com nosso grupo, as moradoras nos contaram que há muito tempo gostariam de plantar espécies de interesse nos espaços verdes da casa, visando uma alimentação mais saudável e consciente. Porém, devido a problemáticas em conseguir ferramentas adequadas para tal ação e comodismo, nunca haviam sequer mexido nestes espaços.

Como o esperado, ao chegar no local os canteiros da casa já possuíam diversas espécies vegetais ornamentais que foram plantadas por antigos moradores e que não cumpriam nenhum papel ecológico no local. Nossa primeira ação foi conversar com as moradoras sobre as espécies de ervas e hortaliças que elas gostariam de plantar, para poder organizar as necessidades e compatibilidades entre as plantas, falar sobre suas necessidades práticas. Depois de estabelecido o plano de manejo, demos dicas e orientação sobre como fazer um bom acompanhamento da horta a partir de uma visão ecológica, falamos sobre os ciclos naturais das espécies; a importância de diversas espécies animais quando em equilíbrio populacional para as bom crescimento das plantas; entre outras informações.

Mas, é no decorrer do manejo quando estamos juntos com a "mão na massa" que aprofundamos nossa conversa para além do cuidado com as plantas ali postas e guiamos a conversa até o debate sobre a relação entre nossas práticas sociais e o planeta terra, que hoje devido às ações humanas encontra-se em grande desequilíbrio. 
Figura 2 - Assessoria verde em república universitária

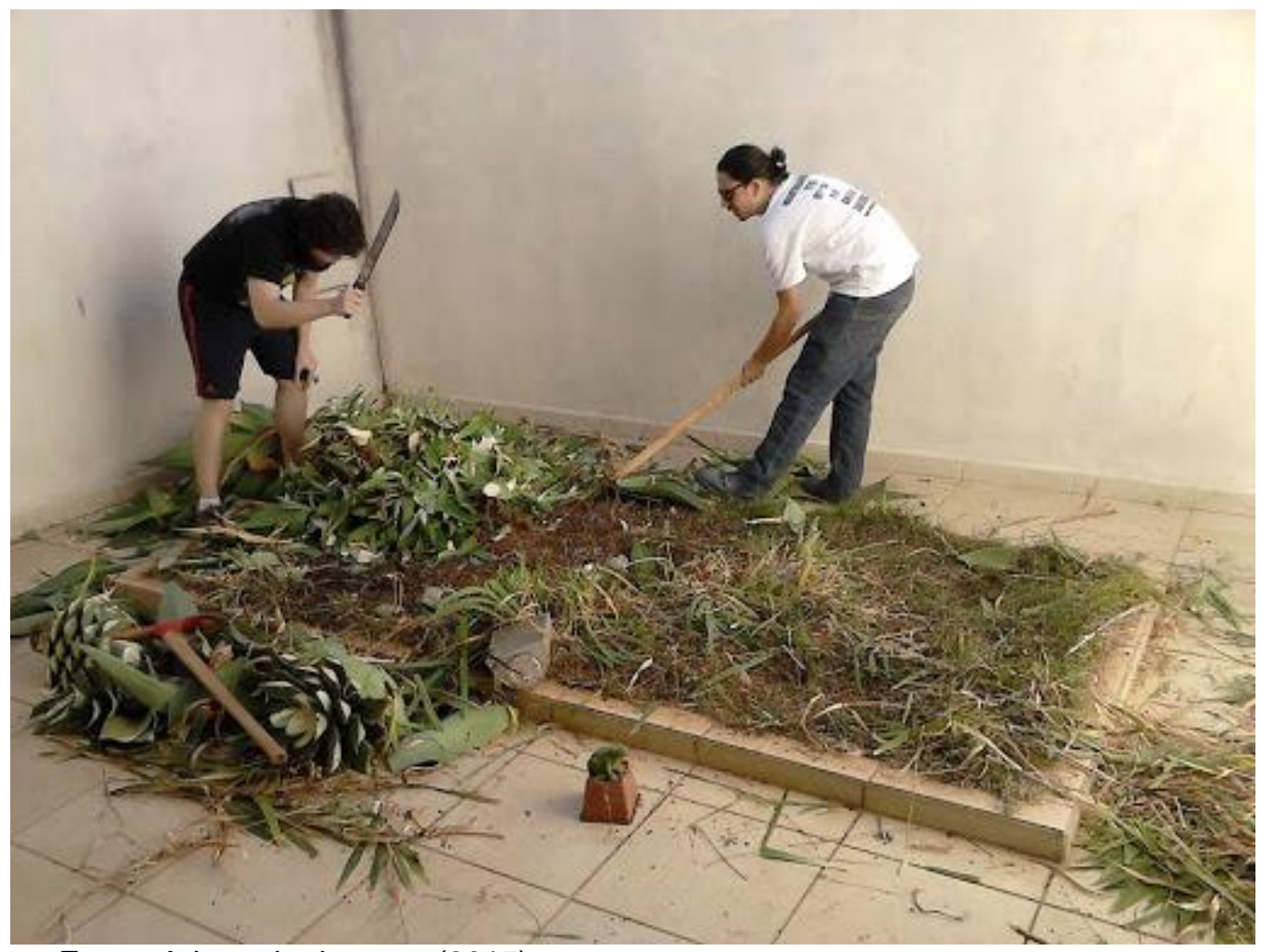

Fonte: Adaptado do autor (2015)

\section{CONSIDERAÇÕES FINAIS}

Por fim, devemos concluir de que o GEIA assume, diante de seu papel social como grupo de extensão, uma postura de constante autorreflexão. Desta forma, sempre depois das práticas e vivências, fazemos questão de estruturar uma discussão em conjunto com os membros que não participaram da atividade, apresentando-lhes as propostas e, assim, estruturar em conjunto novas ideias e posturas ou até mesmo projetos para a cidade.

Contudo, se nos limitarmos à críticas e reflexões internas, deixaríamos para trás diversas lacunas referente a posição do público alvo das atividades. Desta forma, fazemos questão de que os professores e alunos durante e depois das atividades se permitam a nos repassar as impressões e opiniões quanto as atividades, podendo assim inserir na vida de nós do grupo um pouco mais de potência, sabores e cores.

\section{REFERÊNCIAS}

BRASIL. Lei 9.795: Política Nacional de Educação Ambiental. República Federativa do Brasil, 1999. Disponível em: < 
http://portal.mec.gov.br/secad/arquivos/pdf/coea/Lei9795.99.pdf> Acesso em 20 de agosto de 2019.

. Programa Nacional de Educação Ambiental (ProNEA).

MMA/MEC: Brasília, 2003. Documento em consulta nacional. Disponível em:

$<$ http://www.planalto.gov.br/ccivil_03/Leis/L9795.htm> Acesso em 20 de agosto de 2019.

CECCON, Sheila. A Educação Ambiental em Diálogo com os Princípios de Paulo Freire. 2014 Disponível em:

<http://acervo.paulofreire.org:8080/jspui/bitstream/7891/3522/1/FPF_PTPF_01_0445 .pdf> Acesso em 24 de agosto de 2019.

FREIRE, Paulo. Educação como prática da liberdade. São Paulo: Editora Paz e Terra LTDA, 1967. $149 \mathrm{p}$.

- Pedagogia da autonomia: saberes necessários à prática educativa. 25a edição. São Paulo: Editora Paz e Terra LTDA, 1996. 148 p.

. Conscientização: Teoria e Prática da Libertação - Uma Introdução ao Pensamento de Paulo Freire. São Paulo: Cortez \& Moraes, 1979. 53 p.

MEADOWS, Donella H.; MEADOWS, Dennis L.; RANDERS, Jorgen; BEHRENS III, W.W. Limites do Crescimento: Um relatório para o projeto do Clube de Roma sobre 0 dilema da humanidade. São Paulo: Editora Perspectiva, 1973. 167 p.

MORIN, Edgar. Os sete saberes necessários à educação do futuro / Edgar Morin ; tradução de Catarina Eleonora F. da Silva e Jeanne Sawaya ; revisão técnica de Edgard de Assis Carvalho. - 2. ed. - São Paulo : Cortez ; Brasília, DF : UNESCO, 2000. 203 p.

PÁDUA, J. Natureza e projeto nacional. As origens da ecologia política no Brasil. In: (org.). Ecologia e política no Brasil, espaço e tempo. Rio de Janeiro: IUPERJ, 1987. $211 \mathrm{p}$.

RAMOS, Elizabeth C. Educação ambiental: origem e perspectivas in Revista Educar, no 18. Curitiba: Ed. UFPR, 2001. pp. 201-218.

VIOLA, E. O movimento ecológico no Brasil (1974-1986): do ambientalismo à ecopolítica. In: PÁDUA, J. A. (Org.). Ecologia e política no Brasil. Rio de Janeiro: Editora Espaço e Tempo e IUPERJ, 1987. Disponível em: <http://www.anpocs.org.br/portal/publicacoes/rbcs_00_03/rbcs03_01.htm>. Acesso em 10 de julho de 2019. 


\title{
EDUCAÇÃO AMBIENTAL NA RECUPERAÇÃO ECOLÓGICA DA LAGOA DO CAPIM NO RIO SANTA BÁRBARA-SP
}

\author{
BERTELLI, Célio \\ Docente - Uni-FACEF \\ LOPES, Matheus Fernandes A. \\ Licenciatura - UNESP/Franca \\ FALEIROS, Tâmer de Oliveira. \\ Mestrando em Biociências - UNESP/Botucatu
}

\section{INTRODUÇÃO}

A Lagoa do Capim, situada às coordenadas UTM, WGS 84 - 23K 254588.31 E 7708053.84 S, entre os Municípios de Patrocínio Paulista e Franca, no Rio Santa Bárbara, foi recuperada através da ação de diversos atores sociais. O envolvimento de tais atores, no entanto, só foi possível mediante a construção de uma plataforma pedagógica que pudesse justificar e, posteriormente, responsabilizar tais agentes pela salvaguarda das lagoas marginais. Para tal, foi preciso que houvesse a execução em duas etapas distintas, mas que estão inerentemente associadas.

A primeira delas para a recuperação em si, isto é, para a retirada do dreno que impedia a cheia da lagoa marginal com intuito de garantir o espaço livre para o cultivo de arroz. A segunda, da ordem prática, que objetivou resgatar as condições biológicas da área envoltória bem como do interior das águas. Para ambas foi realizado, através das oficinas de educação ambiental - motivadas pelo princípio de ver, observar, fazer e aprender, onde a execução torna-se parte ativa e fundamental do aprendizado - a conscientização da sociedade civil com vistas para sua participação no processo de plantio de mudas nativas e de soltura de peixes juvenis provenientes da Bacia Hidrográfica do Sapucaí-Mirim.

O programa de educação ambiental na recuperação da Lagoa do Capim foi de tamanha efetividade, que até os dias atuais a lagoa marginal permanece conservada e garantindo o pleno funcionamento dos ciclos biológicos naturais existentes antes da ação antrópica. Esse circuito será demonstrado no transcorrer do presente artigo, motivando que outros projetos se assentem sob a perspectiva da educação ambiental como força motriz da execução e da garantia de sua sustentabilidade no tempo. 


\section{METODOLOGIA}

A metodologia do presente artigo se orienta na construção de uma pesquisa qualitativa, através de levantamento bibliográfico e análise exploratória dos documentos e referências. Tal opção estimula, segundo Gil (2002), a abertura de outros projetos que possam incentivar e aprofundar as discussões acerca da potencialidade da educação ambiental na conservação, recuperação e salvaguarda das águas e do meio ambiente.

\section{OBJETIVO}

O objetivo do presente trabalho é evidenciar as potencialidades da educação ambiental na construção de laços para a responsabilização da sociedade civil na defesa e salvaguarda do meio ambiente, através da experiência de recuperação ambiental da Lagoa do Capim, no rio Santa Bárbara-SP. Isto, pois só é possível demandar obrigações coletivas no momento em que a sociedade compreende a relevância das questões ambientais para o melhor convívio social.

\section{REFERENCIAL TEÓRICO}

O Sistema Hídrico da Bacia Hidrográfica do Rio Santa Bárbara encontra-se localizado no Nordeste do Estado de São Paulo. Todavia, o objetivo do presente trabalho é se debruçar sobre o projeto de recuperação da Lagoa Marginal do Capim, de caráter permanente, situada às coordenadas UTM, WGS 84 - 23K 254588.31 E 7708053.84 S (BERTELLI et al, 2016).

São áreas periodicamente ou permanentemente inundadas pelo refluxo lateral de rios ou lagoas e/ou precipitação direta ou água subterrânea. A Lagoa do Capim tem caráter permanente, isto é, não há dependência direta das sazonalidades para que ocorra o preenchimento de seu volume. A importância reside no fato de que:

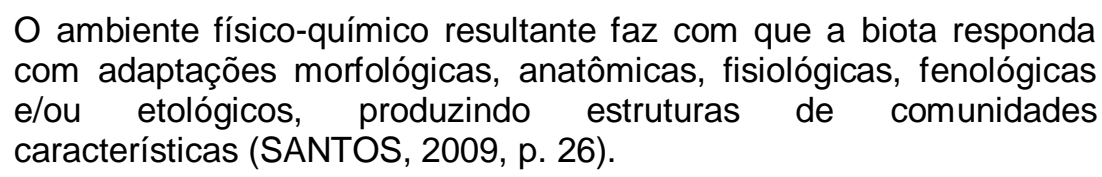

Esse ambiente, por sua vez, garante as condições necessárias para a reprodução dos micro-organismos e de todo tipo de vida aquática que venha a existir na dinâmica fluvial do Rio Santa Bárbara. O que, acaba por engendrar em uma existência simultânea de diversas comunidades, também permitindo uma alta mobilidade social, isto é, demonstra a vivacidade biológica, física e química do rio e, sobretudo, da lagoa marginal.

São as lagoas marginas responsáveis por parte significativa da dinamicidade biológica existente nos perímetros envoltórios dos rios. Entretanto, as lagoas marginais não existem per si, elas dependem de um sistema hídrico mais 
amplo e complexo. Dessa forma, antes de analisá-la é preciso reconhecer dois fatores que antecedem sua condição, mas que, ao mesmo tempo, são completamente interligados e necessários para a existência da lagoa marginal. Ou seja, a lagoa existe em função da dinâmica fluvial dos rios e, sobretudo, do fenômeno piracema. Mas, não é possível discutir a lagoa marginal isolada da compreensão desses fenômenos, bem como das capacidades de influência de tais acontecimentos na existência e durabilidade da própria lagoa. Em síntese, trata-se de um processo com reciprocidade verificável, onde há expectativas de ambas as partes no exercício dos procedimentos biológicos, isto é, tanto do rio para com a lagoa, como da lagoa para com o rio.

O Rio Santa Bárbara apresenta diversas áreas de alagamento identificadas, o que acaba por permitir também a existência de diversos habitats aquáticos e de transição — de aquáticos para terrestres. O potencial de descarga do rio e a área de alagamento é o mecanismo que controla os ambientes cujas mudanças influenciam as várias lagoas formadas às margens do rio. $E$, se isto é verdade, também é verdade que as características químicas, físicas e biológicas estimulam toda a sua fauna e flora a sofrerem influência dos alagamentos.

Dito isso é preciso entender, portanto, os dois maiores eventos que condicionam todo o universo inscrito no sistema hídrico. A dinâmica fluvial, por sua vez, pode ser caracterizada como o movimento que descreve o fluxo e a atividade hídrica existente em determinado rio. Para tal, foram elaboradas diversas teorias ecológicas que se propuseram a pensar e pormenorizar os contornos das comunidades do sistema rio, onde as principais e assumidas como premissa neste artigo são: "Teoria do Continuum Fluvial (VANNOTE et all.1980), a do Pulso de Inundação (JUNK et. al. 1981) e o Conceito de Descontinuidade em Série (WARD \& STANFORD, 1995)". (BERTELLI et al, 2016).

Em linhas gerais, as duas primeiras dizem respeito às características que descrevem a dimensão longitudinal e lateral como sendo as principais geradoras dos processos ambientais no sistema fluvial. A terceira, isto é, a que retrata o conceito de descontinuidade em série, aborda uma concepção que leva em consideração a inserção de obstáculos (represas, barragens e etc) ao longo do trajeto do rio. Dentre os quais seriam grandes responsáveis pelas alterações dos processos bióticos e abióticos compreendidos dentro do sistema rio.

Apesar de apresentarem perspectivas distintas no que tange às maneiras de pensar e propor intervenções no sistema rio, as três assumem premissa comum: há um inegável sistema complexo e totalmente interligado, onde uma simples alteração em determinada localidade, seja pela ação antrópica ou não, pode ser capaz de gerar impactos significantes. Desta forma, elas elucidam a relevância de um projeto que trate das questões levantadas sob um prisma transversal, isto é, considerando todos os elementos possíveis para a resolução de qualquer dificuldade. 
A dinâmica fluvial por sua vez, também é responsável pela geração de outro processo biótico e abiótico de extrema relevância: a piracema. Fenômeno este responsável pela reprodução dos peixes, que garante a pluralidade biológica bem como a sustentabilidade ecológica das águas. Seja na troca de nutrientes, no fechamento do ciclo de reprodução ou mesmo na continuidade do equilíbrio biológico da bacia hidrográfica. O segundo fenômeno que merece atenção diz respeito à reprodução dos peixes, isto é, o fenômeno piracema, que acontece em período exclusivo do ano e é justamente um dos maiores responsáveis pela garantia do equilíbrio ecológicos das águas dos rios.

Ihering (1929) já havia documentado a movimentação de peixes rio acima durante a piracema (palavra indígena que significa pira - peixe e cema - fluxo, cardume) (OLIVEIRA, 2006, p. 20).

Tendo em vista tudo que foi apresentado, torna-se inegável a relevância das lagoas marginais para a conservação do equilíbrio ecológico, uma vez que elas são fundamentais para a reprodução das vidas aquáticas e estas, por sua vez, para garantir o balanço físico-químico das águas.

Dessa forma, é preciso elucidar através da educação ambiental, todos esses fatores destacados, visando capilarizar ao máximo essa temática com a população para promover uma preocupação e conservação coletiva. A melhor forma de introduzir esse debate é justamente por meio de atividades associadas à educação ambiental, objeto fundamental deste trabalho e que sem ela não teria sido possível garantir a recuperação da Lagoa do Capim.

Todo o projeto aconteceu levando em consideração as possibilidades pedagógicas envolvidas em um processo concreto de aprendizado, isto é, onde exista a possibilidade dos educandos envolvidos, de fato, tornarem-se sujeitos ativos.

Essa escolha metodológica foi adotada tendo em vistas as dificuldades de inserção da temática ambiental nas escolas e, sobretudo, com relação à apreensão dos educandos diante de tais conhecimentos. Afinal, a sala de aula muitas vezes é um ambiente estéril para a reprodução de conhecimentos biológicos que lidem com a vida e, principalmente, com a natureza. Paulo Freire já teria indicado isso e apontado caminhos para resolução desse caminho. Perceptível pela citação abaixo:

Creio poder afirmar, na altura destas considerações, que toda prática educativa demanda a existência de sujeitos, um que, ensinando, aprende, outro que, aprendendo, ensina, daí o seu cunho gnosiológico; a existência de objetos, conteúdos a serem ensinados e aprendidos; envolve o uso de métodos, de técnicas, de materiais; implica, em função de seu caráter diretivo, objetivo, sonhos utopias, ideais (FREIRE, 1996, p. 28).

Ou seja, a atividade prática tem condições muito maiores de atingirem seus objetivos durante a ação pedagógica. Afinal, é mediante essa condição concreta que se torna possível a apreensão por parte dos educandos. Ver, 
Observar, Fazer e Aprender torna possível a troca de conhecimento, como também torna possível não apenas a memorização, mas a compreensão de fato.

Compreensão essa que tem maior efetividade justamente por entender os educandos como sujeitos ativos na formação de seu próprio conhecimento, haja vista a atuação diante do mundo. Pois somente essa ação frente à realidade que permite o entendimento e a responsabilidade dos homens diante a conservação, preservação e proteção do meio ambiente.

O caso da recuperação da Lagoa do Capim foi um grande exemplo desse caminho percorrido e adotado pela atividade pedagógica. Foi somente através dessa iniciativa que foi possível concretizar a recuperação de seu papel biológico, resgatando o equilíbrio ecológico do rio, bem como a sucessão biológica das águas em questão.

\section{RESULTADO E DISCUSSÃO}

O projeto motivou-se a recuperar a Lagoa do Capim, localizada nas coordenadas UTM, WGS 84 - 23K 254588.31 E 7708053.84 S. Trata-se de uma lagoa ligada ao Rio Santa Bárbara, situada entre os municípios de Franca-SP e Patrocínio Paulista-SP.

Figura 1 - Dreno que secou a Lagoa do Capim para o plantio de arroz

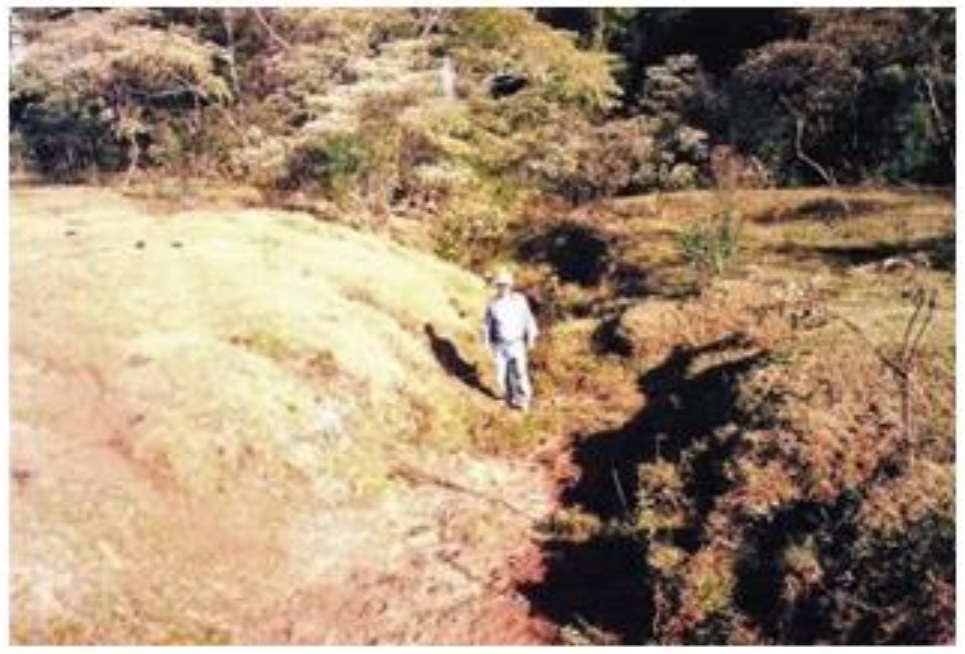

Fonte: Proprietário, Heitor Martinelli, 1995.

Em linhas gerais, a Lagoa do Capim deixou de existir no momento em que foi drenada pelos proprietários para utilização de sua área para o plantio de arroz. O dreno foi realizado no intuito de impedir que aquela determinada área continuasse a encher, tornando possível o plantio e cultivo de arroz com finalidades comerciais. A grande questão é que essa intervenção realizada pelos proprietários 
feria a legislação ambiental, de forma que não era permitida a drenagem de uma lagoa marginal em função de sua relevância biótica e abiótica.

Quando o dreno da lagoa marginal foi retirado, o próprio movimento natural das águas acabou por preencher o volume outra vez. No entanto, a mata ciliar estava debilitada e demandava um plantio que utilizasse mudas nativas para que a recuperação pudesse realmente se viabilizar.

Foi diante dessa circunstância que a parceria entre Franca-SP e Patrocínio Paulista-SP optou por integrar nesse circuito de recuperação alunos de escolas municipais de ambos os municípios. Dando início, finalmente, ao processo de recuperação através do plantio de mudas.

No ano de 1995 que os prefeitos de Franca, Ary Balieiro, e Patrocínio Paulista, Henrique Lopes, representados pelo professor Ivan Vieira e pelo engenheiro Célio Bertelli, deram inícios nas atividades de recuperação propriamente dita. Na época o proprietário da Fazenda Granada era o Sr. Heitor Martinelli. Hoje, apesar do proprietário não ser mais o mesmo, a recuperação realizada se concretizou, garantindo a continuidade do projeto no tempo.

Todavia, antes da atividade prática em si, foram desenvolvidas uma série de atividades pedagógicas envolvendo os educandos com a finalidade de prepará-los e inseri-los na temática em questão. Objetivando, principalmente, que eles pudessem ter noção da dimensão do trabalho a ser desenvolvido antes mesmo da ação prática que o desenvolveu. Após a formação no que diz respeito à importância das lagoas marginais, da dinâmica fluvial e especialmente dos fenômenos bióticos e abióticos que envolvem os rios, como é o caso da piracema, partiu-se para a efetivação do plantio junto das escolas dos dois municípios em questão, assim como da comunidade.

Figura 2 - Recuperação do Dreno, voltando ao dique marginal da Lagoa do Capim

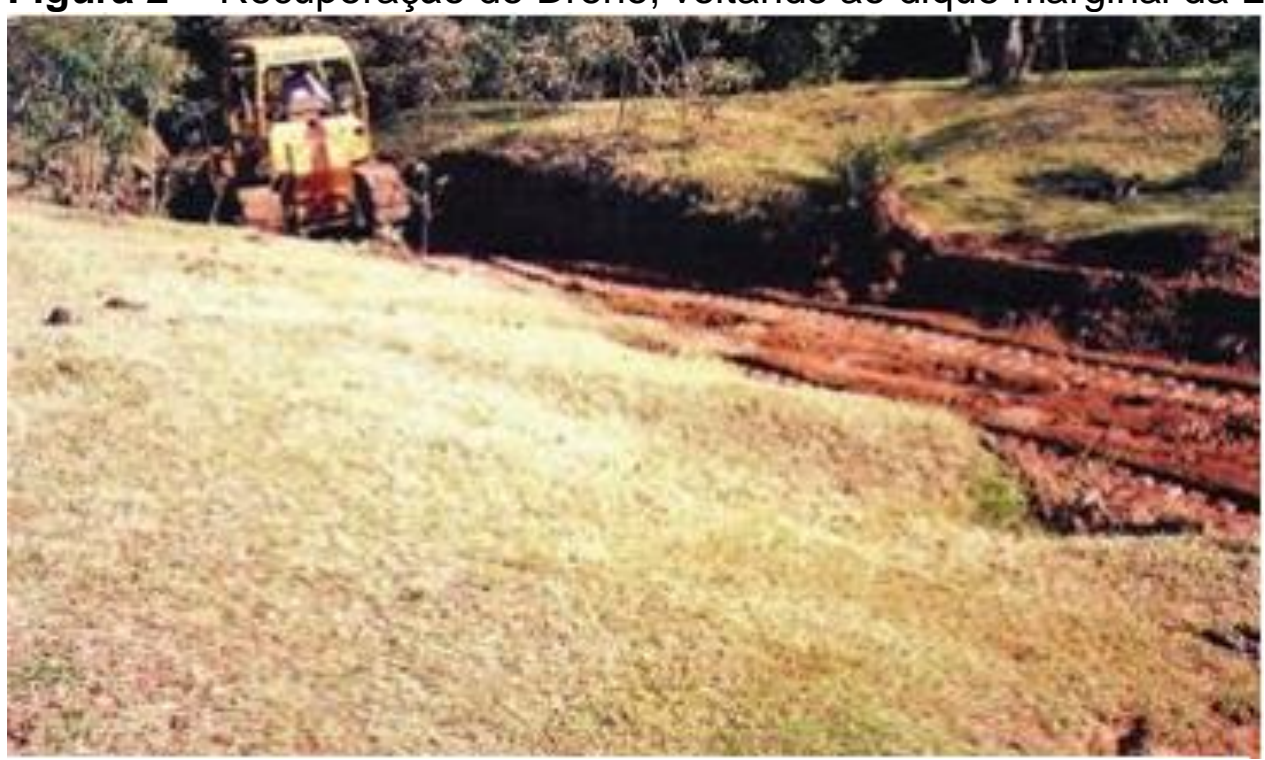

Fonte: Proprietário, Heitor Martinelli, 1995. 
O plantio levou em consideração não apenas alunos da educação infantil, como também pertencentes à sociedade civil que pudessem se interessar pelas questões ambientais. Foi um trabalho interessante, visto que integrou diversas faixas etárias, bem como cidadãos de dois municípios distintos, tudo em prol da recuperação ambiental da Lagoa do Capim.

Figura 3 - Plantio de mudas junto aos alunos de escolas infantis de Patrocínio Paulista e Franca (SP).

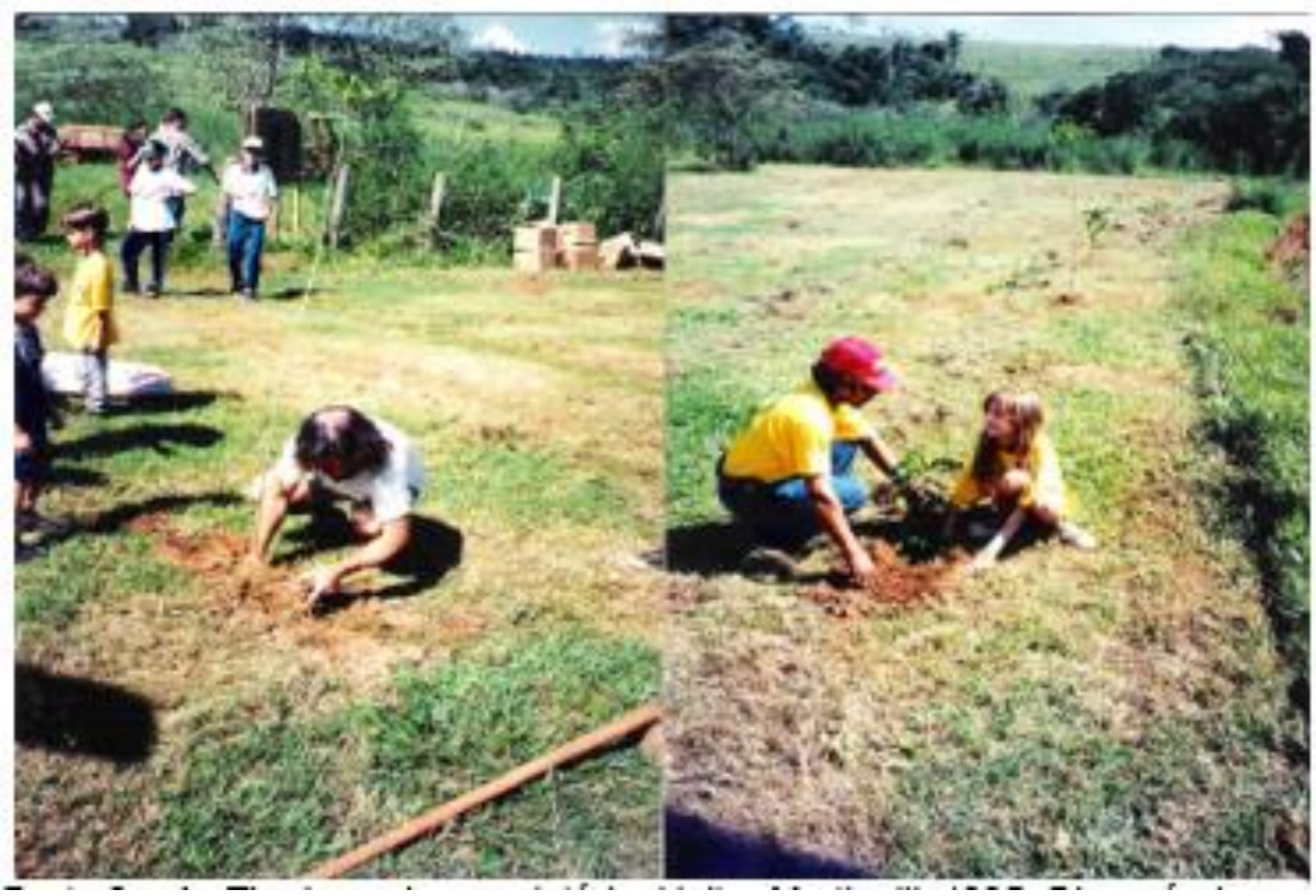

Fonte: P̄roprietário, Heitor Martinelli, 1995. 
Figura 4 - Recuperação do Dreno, voltando ao dique marginal da Lagoa do Capim Sociedade civil e alunos durante plantio da mata ciliar ao redor da Lagoa do Capim

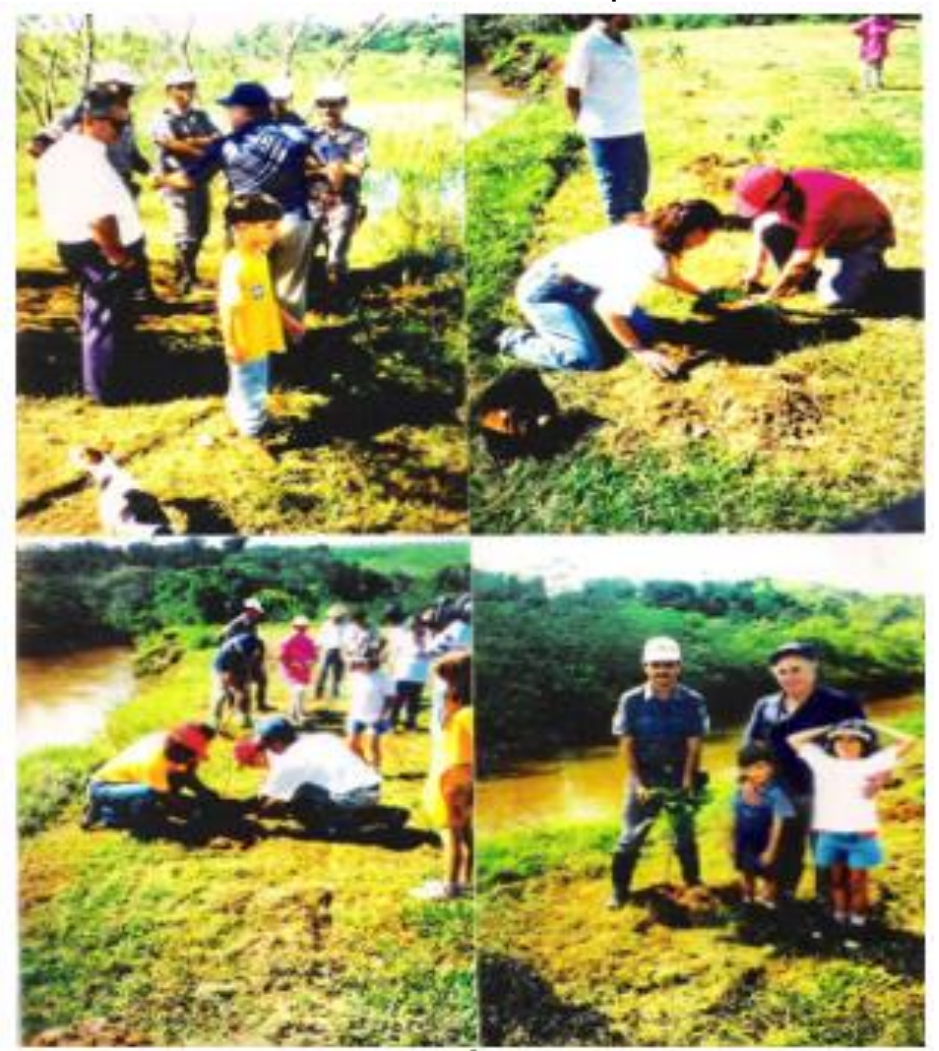

Fonte: Proprietário, Heitor Martinelli, 1995.

Figura 5 - Soltura de peixes juvenis nativos da Bacia Hidrográfica do Sapucaí-Mirim na lagoa do Capim

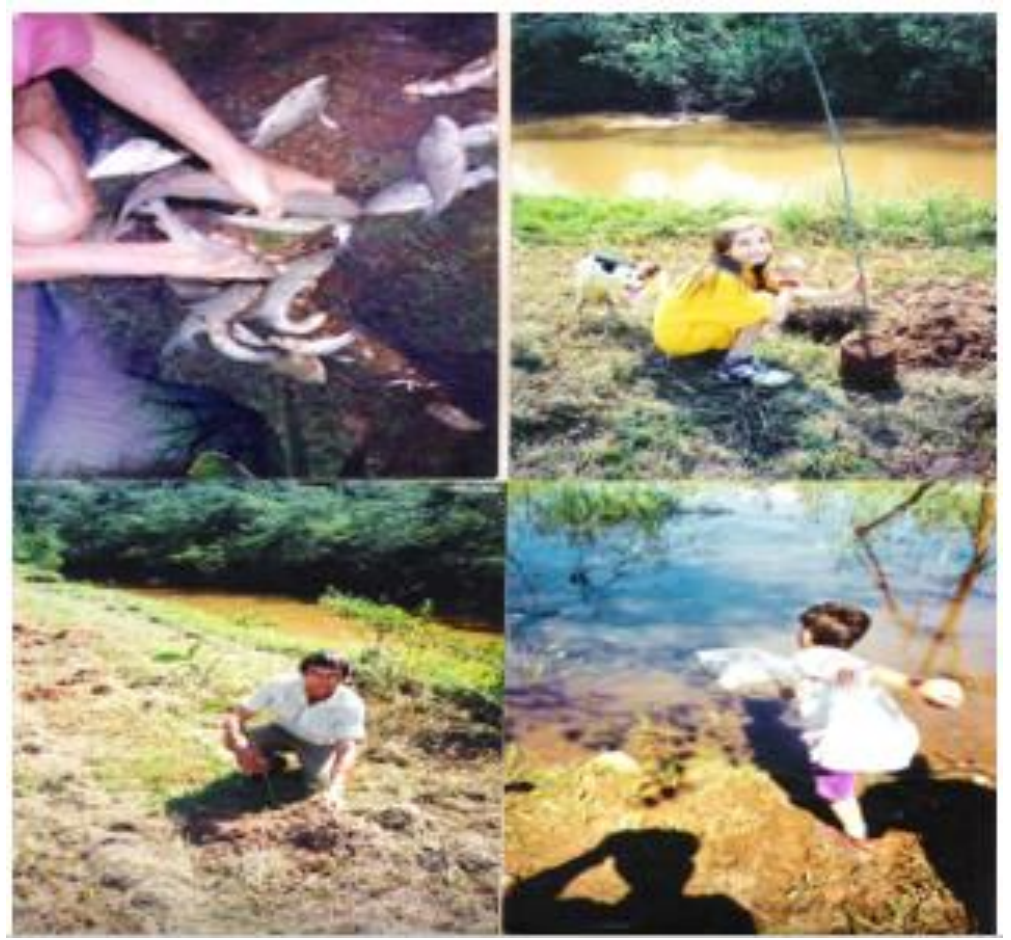

Fonte: Proprietário, Heitor Martinelli, 1995. 
Para além do plantio de mudas nativas, também realizada a soltura de peixes visando a recuperação da fauna proveniente da lagoa marginal. Com intuito principal de reavivar as atividades biológicas, seja pelos peixes ou pelos microorganismos, gerando assim uma maior celeridade na recuperação da lagoa. O que acaba por engendrar também a restauração do equilíbrio ecológico com maior velocidade.

Figura 6 - Sociedade civil envolvida no plantio e soltura de peixes para a recuperação da Lagoa do Capim
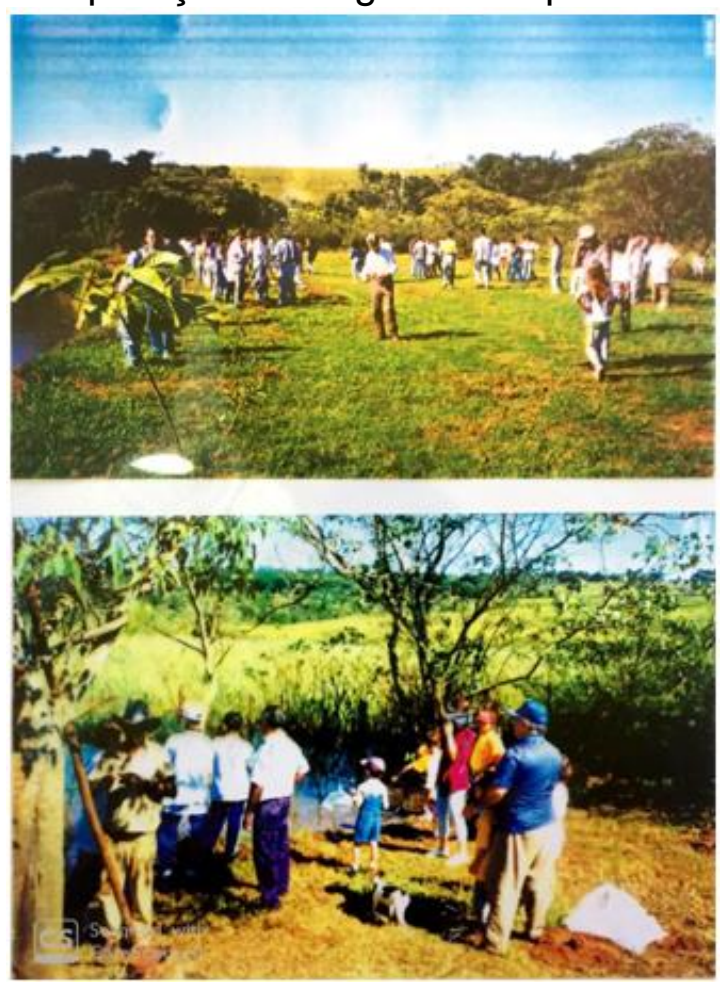

Fonte: Proprietário, Heitor Martinelli, 1995.

Após a realização de todas essas atividades, onde desde o início houve a motivação de integrar os mais diversificados representantes da sociedade técnicos, alunos e civis em geral -, foi possível garantir a recuperação da lagoa, permitindo que a sucessão ecológica fosse alcançada, dando condições para o retorno à condição natural da própria lagoa. 
Figura 7 - Lagoa do Capim, antes e depois da recuperação
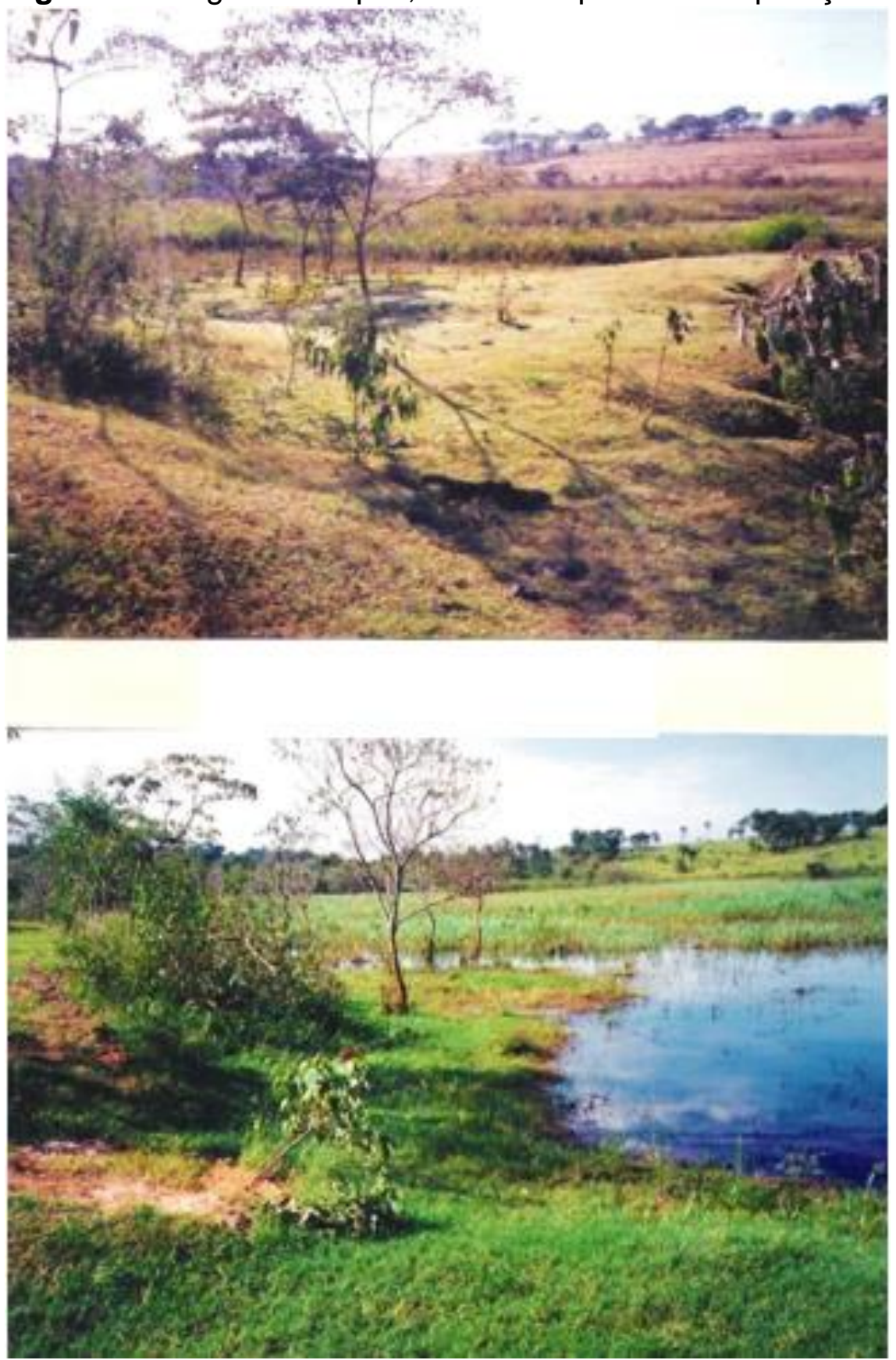

Fonte: Autor, 1996.

A educação ambiental é uma alternativa para longevidade de projetos e programas realizados. Isto, pois ela é o instrumento mais habilitado para a difusão das complexidades e para a socialização dos conhecimentos que irão garantir a responsabilidade de participação da sociedade civil na proteção e preservação do meio ambiente. É preciso compreender sua relevância para que uma agenda coletiva em sua defesa possua eficiência e durabilidade. 


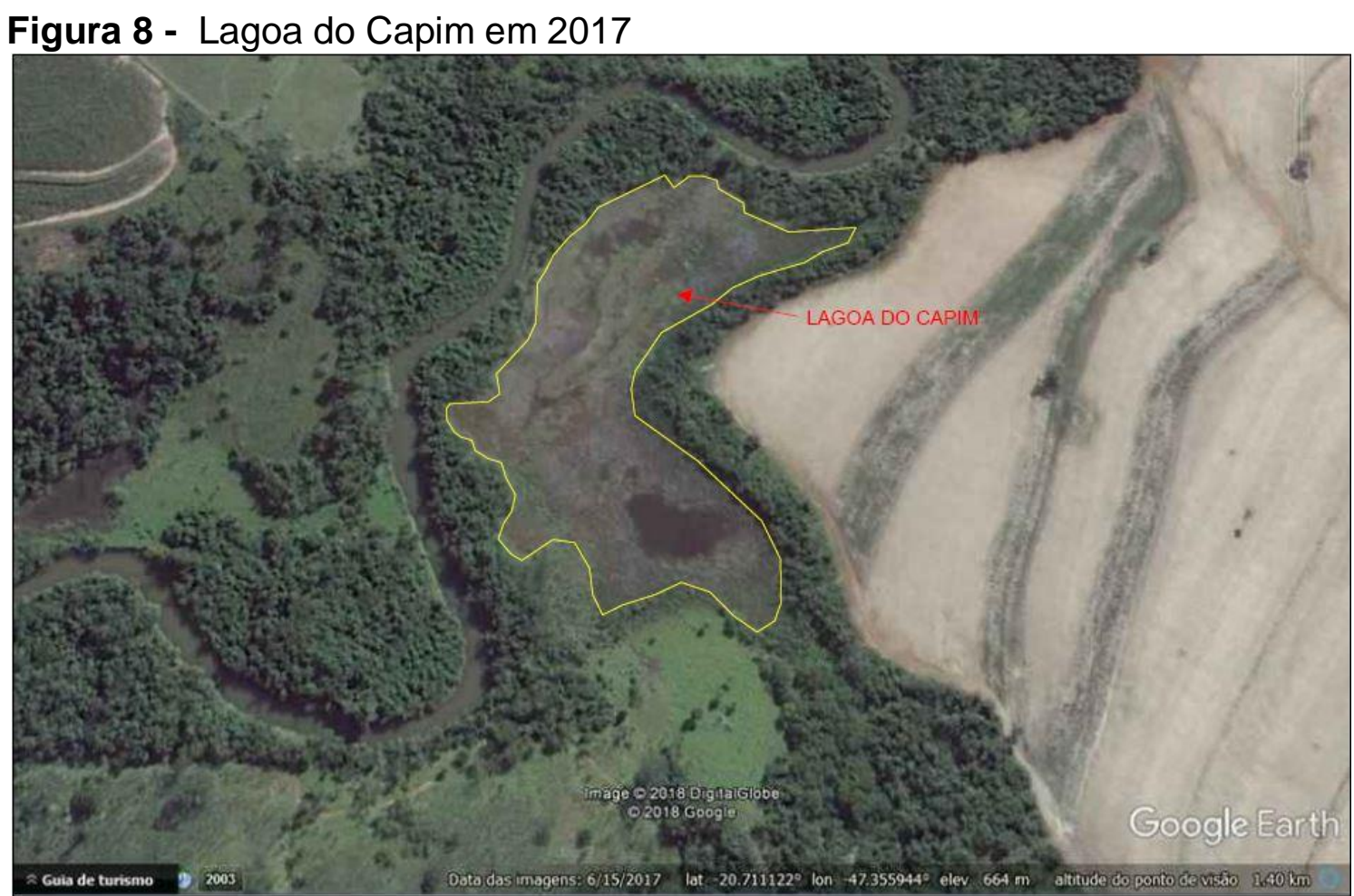

Fonte: Adaptado de Google Earth, 2017..

As recuperações de lagoas marginais, tendo em vista o papel que cumprem para a manutenção da dinâmica harmônica ecológica dos organismos aquáticos, representam um projeto necessário e de extrema importância para a conservação e preservação do meio ambiente. Principalmente pela potencialidade que a lagoa resguarda por si só, isto é, uma pluralidade de efeitos bióticos e abióticos que permitem a reprodução das condições naturais importantes para a garantia da dinâmica fluvial e da piracema, por exemplo.

Todavia, não cabe reconhecer todos esses elementos se os mesmos não fazem parte da compreensão global da sociedade em que se insere. Muitas das recuperações realizadas, mas não construídas em torno de uma plataforma pedagógica, de formação e de democratização do conhecimento, não foram capazes de se perpetuar no tempo. Nesse sentido, a experiência de recuperação tratada aqui comprova a capacidade das oficinas pedagógicas e da difusão do conhecimento na manutenção e salvaguarda de interesses coletivos, sobretudo ambientais.

O sucesso da recuperação da Lagoa do Capim está inerentemente associado às condições criadas para o envolvimento de diversos atores. Para que tal envolvimento fosse criado, foi necessário construir um circuito de formação e conscientização educacional acerca da importância das lagoas para a devida manutenção do meio ambiente. Não fosse a integração construída entre poder público, escolas municipais e a sociedade civil em geral, a responsabilidade coletiva 
desenvolvida através da educação ambiental em defesa da Lagoa do Capim não teria sido firmada.

\section{CONSIDERAÇÕES FINAIS}

A educação ambiental, quando associada à execução de projetos de recuperação e proteção ambiental, tem potencial para garantir maior efetividade. $O$ presente trabalho apresenta como uma plataforma pedagógica pode ser capaz de garantir a longevidade e sustentabilidade de um projeto que teria dificuldades em outras condições.

Nesse sentido, é fundamental começar a pensar as alternativas de recuperação e proteção ambiental associada às potencialidades ainda não exploradas da educação ambiental. Para tal, torna-se imprescindível integrar essa visão às políticas públicas e inserir essa perspectiva ao circuito daqueles projetos ambientais já existentes.

Essa alternativa mostra-se como uma importante ferramenta na coletivização de causas e questões tão importantes ao convívio social, à dinâmica harmônica ecológica e, sobretudo, à participação efetiva da sociedade no planejamento ambiental.

\section{REFERÊNCIAS}

BERTELLI, Célio. PIRES, Daniel Facciolo. SENHORINI, José Augusto. JUNIOR, José Osmar de Sá. FALEIROS, Tâmer de Oliveira. Estudo Espacial das Lagoas Marginais da Bacia do Rio Santa Bárbara: Modelo de planejamento, gestão, proteção e conservação das lagoas marginais. In: Anais do I Seminário de Recursos Hídricos da Bacia Hidrográfica do Sapucaí-Mirim/Grande, 2016. 1 ed. Ecoplans, Franca. p. 29-40

BERTELLI, Célio. Termo de referência de diagnóstico físico, químico e biológico da água, sedimento, peixes e levantamento da ictiofauna e ictiogenética na Bacia Hidrográfica do Rio Sapucaí-Mirim/Grande, 2014.

CHRISTOFOLETTI, A. Modelagem de sistemas ambientais. São Paulo: Edgard Blücher, 2000. 236p.

FREIRE, Paulo. Pedagogia da autonomia: saberes necessários à prática educativa. São Paulo: Paz e Terra, 1996. 25를.

GIL, Antônio Carlos. Como elaborar projetos de pesquisa. 4 ed. - São Paulo: Atlas, 2002

HENRY, R. Os ecótonos são interfaces dos ecossistemas aquáticos: conceitos, tipos, processos e importância. Estudo de aplicação em lagoas marginais ao Rio Paranapanema na zona de sua desembocadura na represa de Jurumirim. In: 
HENRY, R. (org.). Ecótonos nas interfaces dos ecossistemas aquáticos. São Carlos: Rima, p. 1-28, 2003.

INSTITUTO CHICO MENDES DE CONSERVAÇÃO DA BIODIVERSIDADE. Governo Federal do Brasil. Matriz de planejamento - PAN Mogi/Pardo/Grande. IN: Sumário Executivo do Plano de Ação Nacional para a Conservação das espécies ameaçadas da Fauna aquática do ecossistema Mogi Pardo e Grande, 2012.

MACHADO, Neuza Vieira et. al. Almanaque Histórico de Patrocínio Paulista. Local Ribeirão Preto, SP. Editora Legis Summa LTDA, 1985. p.151.

OLIVEIRA, Alexandre Kannebley de. Composição e distribuição da Ictiofauna de tributários do rio Mogi guaçu e do rio Corumbataí, Estado de São Paulo. Tese de Doutorado, 2006. Universidade Federal de São Paulo, Programa de PósGraduação em Ecologia e Recursos Naturais.

SANTOS, Polliana Ferro. Análise de Conectividade entre o Rio São Francisco e Lagoas Marginais: avaliação hidrológica e parâmetros físico-químicos da água. Dissertação de Mestrado apresentada ao curso de Engenharia Ambiental Urbana. Escola Politécnica da Universidade Federal da Bahia. 2009. 


\section{EDUCAÇÃO AMBIENTAL X VIOLÊNCIA ESCOLAR: Uma experiência em uma cidade do interior de São Paulo}

FERREIRA, Marina

BATISTA, Gyovanna Alves

SOUZA, Tatiana Noronha de

Universidade Estadual Paulista "Júlio de Mesquita Filho"/ FCAV/UNESP/Jaboticabal

\section{INTRODUÇÃO}

O presente estudo é fruto das experiências construídas em projetos anteriores do programa dos Núcleos de Ensino da Universidade Estadual Paulista Júlio de Mesquita Filho - UNESP, que desenvolveram trabalhos com a temática da Educação Ambiental (EA) em escolas públicas e intuições filantrópicas de uma cidade do interior do estado de São Paulo. Esses projetos influenciaram a criação do Grupo de Estudos em Educação Ambiental (GEEA), que conta com a participação de alunos de graduação do campus de Jaboticabal e contribui para a ampliação do repertório de conhecimento dos participantes acerca da temática.

Os estudos contribuíram para a adoção de diferentes referenciais teóricos e legais, que sustentam o desenvolvimento do trabalho. Em relação ao conceito de educação ambiental, compartilhamos aquele apresentado pela Política Nacional de Educação Ambiental (PNEA) ao estabelecer a EA como: "[...] processos por meio dos quais o indivíduo e a coletividade constroem valores sociais, conhecimentos, habilidades, atitudes e competências voltadas para a conservação do meio ambiente [...] (BRASIL, 1999, Artigo 1ํ). Essa definição pode ser complementada por aquela apresentada nas Diretrizes Curriculares Nacionais para a Educação Ambiental (DCNEA) ao estabelecer como atividade intencional que deve vislumbrar ao "desenvolvimento individual um caráter social em sua relação com a natureza e com os outros seres humanos, visando potencializar essa atividade humana com a finalidade de torná-la plena de prática social e de ética ambiental. (BRASIL, 2012, Artigo 2º).

Dentre os princípios da EA em ambas legislações, destacamos "o fortalecimento da cidadania, autodeterminação dos povos e solidariedade como fundamentos para o futuro da humanidade (BRASIL, 1999, Artigo 5o, inciso VII). As DCNEA incluem o respeito à diversidade e pluralidade, direito à existência a importância do desenvolvimento de uma cidadania planetária (BRASIL, 2012). Para além dos comportamentos pró-ambientais tradicionais (cuidar diretamente do meio ambiente e promover sua proteção), destacamos o papel da EA na promoção da paz 
e das relações humanizadas entre as pessoas. Assim, o projeto desenvolvido trabalhou a dimensão da educação ambiental no combate à violência escolar, pois a boa qualidade das relações humanas está intrinsecamente articulada à construção de valores de cuidado com o meio ambiente.

Aos buscarmos referências de estudos que utilizaram educação ambiental e promoção da paz, encontramos estudos de diferentes naturezas. Oliveira e Cintrão (2004) partiram da premissa de que a escola é um espaço de convívio social e, dessa forma, espaço de conflitos. Realizaram uma pesquisa com alunos do ensino médio, por meio do uso de questionários, para investigar questões ligadas ao comportamento envolvendo situações de alimentação. Os resultados encaminharam para a criação de uma horta comunitária, que além de trabalhar com questões de segurança alimentar permitiu a socialização dos alunos e promoção da cidadania.

Lima (2010) ao indagar se a educação ambiental pode contribuir para a paz e a sustentabilidade, reflete sobre a violência e suas influências multifatoriais, e analisar as contribuições da educação ambiental na diminuição da violência socioambiental, a partir da democratização do acesso a saberes e práticas que tratam a relação com indivíduo com ele mesmo, e com a sociedade. Para o autor a EA contribui em várias frente, como para a crítica, a epistemologia, a política e ética. Por meio dela é possível desenvolver o pensamento crítico sobre as relações da sociedade e meio ambiente, levando as pessoas a refletirem sobre suas ações, decisões e atitudes.

No campo da epistemologia, a EA vem confrontar paradigmas, pois é voltada para problematizar e desconstruir pensamentos; a política ganha contribuição no sentido de refletir que os problemas ambientais partem de conflitos sociais, podendo a partir disto levantar discussões acerca da participação da sociedade, cidadania ambiental e democratização, assuntos abordados dentro de questões políticas. Por fim, no campo da ética, a EA contribui de diversas maneiras, como refletir sobre os valores que predominam na sociedade, repensar em atitudes no sentido de melhorar a qualidade de vida das pessoas e também incentivar o combate a comportamentos agressivos, sendo exemplos citados pelo autor o individualismo e competitividade (LIMA, 2010).

Ao considerar todos os campos supracitados a EA de alguma forma consegue contribuir, pode-se dizer que por meio das reflexões que promove, como os valores da sociedade, relações entre os seres e entre os seres e o meio ambiente, é possível promover mudanças nas atitudes e pensamentos de educandos imersos em situações violentas cotidianas, para que melhorem suas relações e interações, assim como se conscientizem sobre a violência em todos seus aspectos (LIMA, 2010).

Lopes-Neta (2011) relatam uma experiência que uniu EA, educação matemática, no combate à violência. $O$ trabalho objetivou levantar palavras que 
representavam a importância da escola para 130 alunos de ensino médio. Tinham como pano de fundo a discussão de conservação do patrimônio e como estratégia de trabalho produziram gráficos para a disciplina de matemática. A EA foi tratada como tema transversal na disciplina de matemática, a associada ao debate sobre 0 cuidado com o meio ambiente.

É importante destacar que os conflitos fazem parte da nossa sociedade, mas dentro desses a violência é o que mais chama atenção e preocupa, pois tanto a violência entre os seres humanos, quanto entre os humanos e o meio ambiente no qual estão inseridos, tem se agravado (SANTOS; FORESTI, 2012).

Não é fácil conceituar a violência, entretanto, segundo Santos (2007), o termo significa qualquer ato de intervenção física ou moral de um indivíduo ou grupo contra a integridade de outro indivíduo ou outro grupo. A construção deste conceito está diretamente relacionada às questões sociais, sendo assim, é necessário lembrar que dentro destas questões sociais estão incluídas não apenas as violências dentro das relações humanas, mas também a violência contra a natureza como um todo (SANTOS; FORESTI, 2012).

A violência entre indivíduos, principalmente os jovens, acarreta diversos problemas de saúde e qualidade de vida, atrapalhando em seu desenvolvimento, assim como a violência ambiental pode gerar danos materiais, culturais e simbólicos à todos os tipos de vida existentes e a todos os seres vivos (BRAGA; DELL' AGLIO, 2012 apud LIMA, 2010). Neste contexto, a escola, que por vezes é lugar de diversos tipos de violências, tem um grande de papel de discutir e problematizar a violência em seus variados ambientes, maneiras e níveis. É neste momento que entra a Educação ambiental, sendo um assunto transversal e interdisciplinar que trata das relações entres o meio ambiente e os seres que dele participam, podendo, assim, ser uma estratégia eficiente para tratar da violência neste local.

A EA preocupa-se com as relações do homem com o meio, sendo assim, as formas como se dão as relações sociais são um campo de discussão, em especial, e aqui trabalhada, as relações de violência no ambiente escolar. Sendo assim, sua importância se deve para a melhora da qualidade das relações entre os educandos com seu meio e contribuindo para uma formação mais solidária e cidadã.

O presente texto tem como objetivo fazer um relato de experiência de um projeto de intervenção desenvolvido em uma escola pública paulista, com objetivo de utilizar a EA no combate à violência escolar.

\section{DESENVOLVIMENTO}

O projeto foi desenvolvido foi feito junto a duas turmas do Ensino Fundamental II de uma escola da rede pública paulista do interior do estado de São 
Paulo. Destaca-se que é uma escola de período integral, na qual os alunos permanecem durante todo o dia em sala de aula. Não há atividades artísticas ou alternativas às aulas tradicionais.

A sequência didática foi elaborada previamente e enviada para uma professora coordenadora na Diretoria Regional de Ensino - DE. Após análise a DE indicou a escola que poderia receber o projeto e em seguida foi realizada uma reunião com a equipe gestora da escola, responsável pela $\mathrm{DE}$, duas estudantes de licenciatura que desenvolveriam o projeto, e a docente coordenadora do projeto.

Caracterização dos participantes e da escola

A primeira turma do 9ano possuía em média 26 alunos com idades entre 14 e 15 anos. Na turma do $8^{\circ}$ ano havia em média 20 alunos, com idades variando entre 13 e 15 anos. A sala também possuía um aluno com necessidades especiais, tendo ele alguns problemas graves cognitivos e de deficiência motora.

A escola está situada em um grande prédio antigo do centro da cidade. Existem salas de aula no primeiro andar e térreo, sala da informática, sala de vídeos, laboratório, biblioteca, um grande pátio e quadra poliesportiva. As salas de aula são pequenas em relação a quantidade de alunos por turma, possuem ventiladores, mas em razão do clima da cidade são extremamente quentes.

Além do calor, um aspecto físico problemático foi a localização da sala de vídeo e biblioteca, que se encontram no andar superior. Estas são acessadas apenas por escadas, não tendo acessibilidade para pessoas com deficiências físicas (como por exemplo, pelo aluno que apresenta deficiência motora). Neste caso, uma questão se coloca: não há uma violência na organização ambiental, para com a criança com problemas de mobilidade? como os alunos podem cuidar de um ambiente que lhes parece hostil?

\subsection{Estratégias utilizadas}

Inicialmente o projeto foi apresentado aos alunos, e foi realizado o Levantamento de Conhecimentos Prévios dos educandos. Neste levantamento foram apresentadas questões como: "O que você entende por Meio Ambiente?"; "Quais os tipos de meio ambiente que fazem parte do seu cotidiano?"; "O que é violência pra você?"; "Você acredita que tenha violência na sua escola? De que tipo, pode exemplificar."; "Quais as maneiras que você acredita que podem combater a violência?"; "O que você acha que é educação ambiental?" e "Como você acredita que a Educação Ambiental possa ajudar a combater a violência?".

Além desse levantamento foi aplicada uma adaptação do questionário Juventude Brasileira adaptado da Escola Municipal Padre Guilherme Peters/ 
Pesquisa: Violência no interior da escola. Este questionário foi aplicado afim de conseguirmos conhecer as características dos alunos e o que traziam de conhecimento e experiência em suas rotinas de vida. Isso também contribuiria para sabermos como lidar com certas situações e abordar assuntos, além de ajudar em como tratar com as características dos alunos e, posteriormente, nos ajudar nas análises dos resultados.

Foi perguntado o nome dos alunos, idade, bairro onde moravam, religião (se possuía ou não e qual), se participavam de atividades extraclasse e se já sofreram algum tipo de preconceito, além de outras questões pessoais como: "Você já foi reprovado?"; "Você já foi expulso de alguma escola?"; "Você tem algum problema mental/psicológico ou dos nervos?". No questionário também continha questões acerca da violência, como: "Na internet você já presenciou algum tipo de violência, qual?"; "Você já ouviu falar do cyberbullying?"; "Você já vivenciou algum tipo de violência contra a natureza?"; "Você acha que na sua escola tem violência?"; "Na sua opinião, a conversa poderia resolver problemas e evitar muitos casos de violência?" e "Na sua opinião, é mais fácil resolver os problemas usando a violência?".

Abaixo apresentamos um quadro com as estratégias utilizadas nas salas, que foram alteradas do planejamento original para que se adequassem às demandas apresentadas pelos alunos.

Quadro 1 - Temas trabalhados e estratégias utilizadas

\begin{tabular}{|c|c|c|}
\hline Tema & Metodologia 9 Ano & Metodologia 8ㅇ Ano \\
\hline $\begin{array}{l}\text { Levantamento de } \\
\text { conhecimentos } \\
\text { prévios e contrato } \\
\text { pedagógico }\end{array}$ & $\begin{array}{l}\text { - Questionários } \\
\text { - Discussão das respostas }\end{array}$ & $\begin{array}{l}\text { - Questionários } \\
\text { - Discussão das respostas }\end{array}$ \\
\hline $\begin{array}{l}\text { Violência e Meio } \\
\text { ambiente }\end{array}$ & $\begin{array}{l}\text { - Elaboração de desenhos } \\
\text { - Apresentação para sala } \\
\text { - Discussão }\end{array}$ & $\begin{array}{l}\text { - Elaboração de desenhos } \\
\text { - Apresentação para sala } \\
\text { - Discussão }\end{array}$ \\
\hline $\begin{array}{c}\text { Violência e } \\
\text { ambiente escolar }\end{array}$ & $\begin{array}{l}\text { - Vídeo “Era uma vez uma família" } \\
\text { - Discussão sobre o vídeo } \\
\text { - Encenação dos alunos de situações } \\
\text { de violência } \\
\text { - Discussão e resolução das } \\
\text { situações } \\
\text { - Vídeos sobre mudanças dos alunos } \\
\text { para melhorias com a escola e a } \\
\text { comunidade escolar } \\
\text { - Discussões sobre o vídeo e } \\
\text { proposição de alternativas }\end{array}$ & $\begin{array}{l}\text { - Vídeo "Era uma vez uma } \\
\text { família” } \\
\text { - Discussão sobre o vídeo } \\
\text { - Encenação dos alunos de } \\
\text { situações de violência } \\
\text { - Discussão e resolução das } \\
\text { situações } \\
\text { - Confecção individual de } \\
\text { cartas }\end{array}$ \\
\hline $\begin{array}{c}\text { Solidariedade e } \\
\text { empatia }\end{array}$ & $\begin{array}{l}\text { - Elaboração de projetos de respeito } \\
\text { e combate a violência que } \\
\text { abarcassem a comunidade escolar } \\
\text { - Apresentação dos projetos para a } \\
\text { direção } \\
\text { - Reaplicação do questionário (LCP) }\end{array}$ & $\begin{array}{l}\text { - Dinâmica "Conhecimento } \\
\text { mútuo" } \\
\text { - Dinâmica "O indivíduo" } \\
\text { - Dinâmica "Jogo dos } \\
\text { Estereótipos" } \\
\text { - Discussão }\end{array}$ \\
\hline
\end{tabular}


Verifica-se que o planejamento procurou se afastar do modelo escolar tradicional, permitindo a participação ativa e o diálogo com os estudantes. Compreende-se a base para a ressignificação das relações com as pessoas e com o ambiente passa pelo diálogo e pela reflexão coletiva.

Buscou-se realizar a discussão e vídeos, planejamento de atividades para a solução de problemas, reflexões sobre estereótipos, atividades de expressão plástica, elaboração de projetos.

\section{RESULTADOS E DISCUSSÃO}

Os dados do questionário já foram apresentados no Congresso Brasileiro de Educação de 2019, e mostram que as meninas sofreram mais violência, e que a maior parte dos meninos. Como podemos ver no quadro abaixo:

Quadro 2 - Dados relativos a preconceitos sofridos pelos alunos e violência vivida e observada

\begin{tabular}{|l|c|c|c|c|}
\hline \multirow{2}{*}{ Campos investigados } & \multicolumn{2}{c|}{$\mathbf{8}$ ano } & \multicolumn{2}{c|}{$\mathbf{9}$ ano } \\
\cline { 2 - 5 } & Masculino & Feminino & $\begin{array}{c}\text { Masculin } \\
\text { 0 }\end{array}$ & Feminino \\
\hline Preconceito de gênero & - & 1 & - & - \\
\hline Cor da pele & - & 3 & - & 1 \\
\hline Característica dos cabelos & 1 & 5 & - & 5 \\
\hline Religião & - & 2 & 2 & 1 \\
\hline Aparência física & - & 3 & 5 & 4 \\
\hline Orientação sexual & - & 1 & 1 & 1 \\
\hline Nunca sofreu preconceito & 6 & - & 8 & 2 \\
\hline Nunca presenciaram violência na internet & 4 & 1 & 5 & - \\
\hline Presenciaram violência na internet & - & 4 & 4 & 5 \\
\hline Verbal/Discussão & - & 2 & - & - \\
\hline Agressão contra a mulher & - & 1 & - & 1 \\
\hline Preconceito & - & - & 4 & 3 \\
\hline Presenciaram violência contra a natureza & 3 & 3 & 8 & 5 \\
\hline Queimadas/Desmatamento & 2 & 3 & 6 & 3 \\
\hline Jogar lixo na rua/chão & - & - & 1 & 1 \\
\hline Não observou violência na escola & 1 & - & 3 & - \\
\hline Observou violência na escola & 9 & 7 & 13 & 10 \\
\hline Agressões físicas e brigas & 7 & 6 & - & - \\
\hline Agressões verbais/xingamentos & 5 & 3 & 10 & 8 \\
\hline Bullying & 1 & - & 4 & 4 \\
\hline Socos & 2 & - & 1 & - \\
\hline Chutes & 1 & - & - & - \\
\hline Preconceitos & - & - & - & 1 \\
\hline Observou violência na sala de aula & 6 & 4 & 7 & 5 \\
\hline Agressões físicas e brigas & - & 3 & 3 & 1 \\
\hline Agressões verbais/xingamentos & - & 1 & 6 & 2 \\
\hline Bullying & 3 & - & - & 2 \\
\hline Socos/Chutes & - & 3 & - & - \\
\hline Preconceito & - & - & - & \\
\hline
\end{tabular}

EDUCAÇÃO AMBIENTAL X VIOLÊNCIA ESCOLAR: Uma experiência em uma cidade do interior de São Paulo - pp. 32-41 


\begin{tabular}{|c|c|c|c|c|}
\hline Sofreu ameaças e humilhações na escola & 4 & 7 & 4 & 6 \\
\hline Sofreu socos e surras & 2 & 2 & 5 & 5 \\
\hline $\begin{array}{l}\text { Acredita que violência pode combater a } \\
\text { violência, em alguns casos }\end{array}$ & - & 4 & 3 & 2 \\
\hline $\begin{array}{l}\text { Não acredita que violência se combate com } \\
\text { violência, mas com diálogo. }\end{array}$ & 10 & 3 & 4 & 3 \\
\hline $\begin{array}{l}\text { Acredita que a violência em casa influencia } \\
\text { na escola }\end{array}$ & 9 & 7 & 6 & 5 \\
\hline Entende o diálogo forma de combate & 10 & 5 & 11 & 10 \\
\hline Entende xingamento como violência & 8 & 5 & 6 & 9 \\
\hline Combate a violência através do respeito & 6 & 5 & 10 & 8 \\
\hline Combate a violência através da solidariedade & 1 & - & - & - \\
\hline Combate a violência por meio da amizade & 1 & - & 4 & 1 \\
\hline $\begin{array}{l}\text { Combate a violência por meio da promoção } \\
\text { de conversa }\end{array}$ & 3 & 4 & 3 & 2 \\
\hline
\end{tabular}

Fonte: Quadro elaborado pelas autoras

No que se refere ao levantamento de conhecimentos prévios, a maioria alega que a educação ambiental pode contribuir para a diminuição da violência, como pode ser visto no quadro abaixo.

Quadro 3 - Questões presentes no Levantamento de Conhecimentos Prévios-LCP e categorias identificadas*

\begin{tabular}{|c|c|c|}
\hline Questões & $8 \%$ ano & 9 ano \\
\hline $\begin{array}{l}\text { O que você entende por } \\
\text { meio ambiente? }\end{array}$ & $\begin{array}{l}\text { Lugar de existência da } \\
\text { natureza (sem os humanos) } \\
\text { - } 9 \text { respostas } \\
\text { Lugar onde vivemos }-6 \\
\text { respostas Cuidar do } \\
\text { ambiente }-3 \text { respostas }\end{array}$ & $\begin{array}{l}\text { Lugar de existência da natureza } \\
\text { (sem os humanos) }-11 \\
\text { respostas } \\
\text { Lugar onde vivemos }-1 \text { resposta } \\
\text { Cuidar do ambiente }-10 \\
\text { respostas }\end{array}$ \\
\hline $\begin{array}{l}\text { Quais tipos de meio } \\
\text { ambiente fazem parte do } \\
\text { seu cotidiano? }\end{array}$ & $\begin{array}{l}\text { - Natureza: } 3 \text { respostas } \\
\text { - Sensação: } 1 \text { resposta } \\
\text { - Associa com o cotidiano: } \\
4 \text { respostas }\end{array}$ & $\begin{array}{l}\text {-Natureza: } 15 \text { respostas } \\
\text {-Associa com o cotidiano: } 2 \\
\text { respostas }\end{array}$ \\
\hline $\begin{array}{l}\text { O que é violência pra } \\
\text { você? }\end{array}$ & $\begin{array}{l}\text { - Agressão Física: } 11 \\
\text { respostas } \\
\text { - Agressão verbal e física: } 6 \\
\text { respostas }\end{array}$ & $\begin{array}{l}\text { - Agressão Física: } 4 \text { respostas } \\
\text {-Agressão Verbal e Física: } 17 \\
\text { respostas } \\
\text {-Desrespeito: } 3 \text { respostas } \\
\text {-Agressão a Natureza: } 1 \text { resposta }\end{array}$ \\
\hline $\begin{array}{l}\text { O que é educação } \\
\text { ambiental para você? }\end{array}$ & $\begin{array}{l}\text { - Ato de cuidar e respeitar a } \\
\text { natureza: } 9 \text { respostas } \\
\text { - Estuda a importância do } \\
\text { meio ambiente, problemas } \\
\text { e soluções: } 9 \text { alunos. }\end{array}$ & $\begin{array}{l}\text { - Ato de cuidar e respeitar a } \\
\text { natureza: } 8 \text { respostas } \\
\text {-Estuda a importância do meio } \\
\text { ambiente, problemas e soluções: } \\
7 \text { respostas }\end{array}$ \\
\hline $\begin{array}{l}\text { Como você acredita que a } \\
\text { Educação } \quad \text { Ambiental } \\
\text { possa ajudar a combater }\end{array}$ & $\begin{array}{l}\text { - Ensinando a se relacionar } \\
\text { com respeito - com outras } \\
\text { pessoas e o meio }\end{array}$ & $\begin{array}{l}\text { - Ensinando a se relacionar com } \\
\text { respeito - com outras pessoas e } \\
\text { o meio ambiente: } 20 \text { respostas }\end{array}$ \\
\hline
\end{tabular}




\begin{tabular}{|l|l|l|}
\hline a violência? & $\begin{array}{l}\text { ambiente: } 9 \text { respostas } \\
\text { - Não acredita que pode } \\
\text { contribuir: } 1 \text { resposta }\end{array}$ & $\begin{array}{l}\text { - Contribuindo com sanções a } \\
\text { quem pratica atos violentos: } 4 \\
\text { respostas }\end{array}$ \\
\hline
\end{tabular}

Fonte: Autoras, 2019.

\subsection{Sala do $9^{\circ}$ Ano}

Nesta sala observamos que os alunos eram agitados e no início da sequência não conseguiam respeitar e organizar suas falas no devido momento, o que foi melhorando ao longo dos encontros. Nesta turma, os educandos se mostraram participativos no decorrer das atividades, apesar de alguns comportamentos de indisciplina, como gritar durante a fala de um colega e uso de xingamentos e, além disso, mostraram-se criativos na elaboração de projetos propostos na sequência didática. Também foi observado comportamento de bullying para com um aluno específico da sala, o que trouxe grande preocupação durante os encontros e, que tentou ser conversado e trabalhado com os alunos no decorrer da sequência.

\subsection{Sala do $8^{\circ}$ Ano}

A sala apresentava grandes casos de indisciplina, como xingamentos, carteiras e paredes riscadas e desenhadas, muito lixo no chão (caracterizando uma violência existente com o ambiente no qual se inserem), agressão verbal e física entre os alunos, além da má relação entre os alunos e a escola (possuíam problemas para aceitar qualquer autoridade da escola, respondendo apenas com punições e ameaças da coordenação), ou seja, havia uma grande falta de respeito com o outro. Situações de roubo de materiais dos colegas e material da escola também ocorreram durante os encontros. Os alunos apresentaram dificuldades para desenvolver as atividades, além de muitas vezes não as realizar.

O desenvolvimento do projeto passou por vários desafios, em função da resistência de alguns alunos. Isso porque as turmas eram estigmatizadas pela gestão da escola, que nos apresentou utilizando adjetivos negativos. Os jovens já tinham incorporado o "rótulo" de turmas mais "difíceis" ou que os "ninguém gostava". Nos registros realizados pelas universitárias verifica-se que parte dos alunos se envolvia nas atividades, e outros se mostravam resistentes às intervenções, até o final do projeto.

A primeira turma conseguiu desenvolver os projetos propostos no final dos encontros, e apresentou melhores resultados do que a segunda turma. Esta última ofereceu maior resistência ao trabalho, mesmo dando espaço para o protagonismo juvenil. Entendemos que a ampliação do tempo seria fundamental 
para a obtenção de melhores resultados do trabalho, assim como a união dos demais profissionais, no trabalho com o grupo.

Presenciou-se xingamentos entre os colegas de classe, como atitudes corriqueiras que atravessavam a forma deles se relacionarem, havia uma tensão e uma agressividade no ar, segundo relatos das graduandas. Eles não paravam facilmente de se atacar, nem com intervenção dos adultos. Aliás, destacamos que a figura dos adultos era fortemente rejeitada pelos jovens, e por isso o ganho de confiança em relação às universitárias, foi lento.

Ao mesmo tempo que alguns jovens se mostraram envolvidos e criativos na elaboração de projetos propostos na sequência didática, é importante destacar que entendemos que a escola deveria identificar as diferentes disposições e abertura dos alunos, de modo a propor intervenções para a melhoria da qualidade das relações. Verificou-se que seria necessário planejar diferentes intervenções no grupo, em função das diferentes características dos alunos.

\section{CONSIDERAÇÕES}

Ações de combate à violência escolar não podem ser restritas a poucos horários, projetos e ações pontuais. As escolas estão preocupadas com 0 cumprimento dos conteúdos tradicionais, e não oferecem espaço para um trabalho mais lento e reflexivo com os alunos. Observa-se a falta de envolvimento de toda comunidade escolar, da postura comprometida e solidária dos gestores, e do combate a qualquer tipo de discriminação por parte dos profissionais.

Observamos que a escolha de colocar em duas salas os chamados "alunos problema", só potencializou os problemas de relacionamento entre os jovens, e destes para com os adultos. Esse tipo de estratégia facilita o processo de estigmatização dos jovens e não contribui para a construção da cidadania, para a garantia do ensino e dos processos democráticos.

O tempo destinado pela escola para a realização dos encontros foi pequeno, tendo em vista que o currículo está cada vez mais engessado e controlado pelo sistema de ensino, o que dificulta a inclusão de conteúdos que estão fora do currículo tradicional.

Conclui-se que a preocupação com o desenvolvimento de habilidades socioemocionais, por enquanto, não se efetiva na escola pública, tendo em vista que há uma maior preocupação com os conteúdos avaliados nas provas, do que com a formação integral dos jovens. As habilidades socioemocionais são construídas não em disciplinas e projetos pessoais, mas por meio de relações respeitosas e permeadas por muito diálogo e reflexão, pois não se trata de um conteúdo a ser aprendido, mas algo a ser vivenciado. 


\section{REFERÊNCIAS}

BRAGA, L. L.; DELL'AGLIO, D. D. Exposição à violência em adolescentes de diferentes contextos: família e instituições. Estudos de Psicologia, Natal, v. 17, n. 3, p. 413-420, 2012.

BRASIL. RESOLUÇÃO № 2, DE 15 DE JUNHO DE 2012. Estabelece as Diretrizes Curriculares Nacionais para a Educação Ambiental. Ministério da Educação. Conselho Nacional de Educação. 2012.

BRASIL. Política Nacional de Educação Ambiental. LEI N 9.795, DE 27 DE ABRIL DE 1999. Presidência da República, Casa Civil, 1999.

LIMA, G. F. C. Violência e meio ambiente: pode a educação ambiental contribuir para a paz e a sustentabilidade?. Revista Espaço do Currículo, v. 2, n. 2, p. 231247, 2010.

SANTOS, Leandro Gabriel dos. A percepção discente da violência escolar: um estudo comparado (tipo de escola, ambiente social e estilo de vida). 2007. $138 \mathrm{f}$. Dissertação (Mestrado em Educação). Universidade de Brasília, Brasília, 2007.

SANTOS, J. C.; FORESTI, J. Gestão escolar e a violência: alternativas educacionais, p. $1-16,2012$.

OLIVEIRA, J. M. D.; CINTRÃO, J. F. F. Violência escolar e Horta Comunitária: a educação ambiental enquanto agente de socialização. Revista Brasileira Multidisciplinar. V. 8, n. 2, 2004.

LIMA, G. F. C. Violência e meio ambiente: pode a educação ambiental contribuir para a paz e a sustentabilidade?. Revista Espaço do Currículo, v.2, n. 2, 2010.

LOPES-NETA, N. de A. A articulação entre a educação ambiental e a educação matemática como meio de diminuir a violência dentro da escola. X Congresso Nacional de Educação. Curitiba, 2011. 


\title{
EDUCAÇÃO AMBIENTAL: Pesquisa-ação realizada no Programa Projovem Adolescente de Franca (SP)
}

\author{
BOVO, Lúcia R. T. \\ Mestre - UNESP/Franca \\ GUIMARÃES, Orlinéya M. \\ Doutoranda - UNESP/Franca
}

\section{INTRODUÇÃO}

Nas últimas décadas, grandes tragédias vêm ocorrendo em nosso planeta, causando devastações bem como prejuízos ambientais, sociais e econômicos. Eventos como tempestades, furacões, enchentes, tsunamis, incêndios e secas são experiências que têm como consequências perdas de vidas humanas e destruição de modos de subsistência.

Diante desta situação, torna-se imprescindível uma alteração na percepção dos valores e das atitudes perante o meio ambiente de modo a estimular a humanidade a tomar consciência profunda e duradoura desses problemas, equacionando-os em busca da perspectiva de sustentabilidade.

Para isto, recorre-se à percepção da questão ambiental através da visão que os jovens brasileiros têm sobre o meio ambiente, buscando compreender nesta análise como os mesmos enfrentam os problemas ambientais da contemporaneidade.

Hoje se presencia um acelerado processo de globalização e múltiplas desigualdades sociais. Os jovens deste novo século compartilham uma experiência geracional (CARRANO; MARTINS, 2007) historicamente inédita e vivem em um mundo que conjuga diversos conhecimentos e novas tecnologias.

Entender o que é ser jovem além dos estereótipos e estigmas (GOOFMAN, 1975) que os definem, pode contribuir para elaboração de políticas públicas mais eficientes e adequadas às suas necessidades.

No Brasil, segundo dados do Instituto Brasileiro de Geografia e Estatística (IBGE), a população juvenil representava em 2008, cerca de 50 milhões de pessoas com idade entre 15 a 29 anos, correspondendo a $26 \%$ da população total (IBGE, 2010). Entretanto, a pesar de ser uma quantidade expressiva da população, a problematização dos direitos dos jovens é recente no país.

A população jovem do Brasil é grande, diversa e abarcada por desigualdades. Nos anos 1990, as questões que envolvem os temas a respeito 
desta faixa etária da população começam a ganhar mais espaços nas políticas públicas.

Em si tratando de meio ambiente, a Educação Ambiental pode ser uma alternativa para que esses jovens busquem conhecimentos e ensinamentos que contribuem para um diálogo entre si e incluindo tema meio ambiente em seu grupo de amigos. Com isso, os jovens se preparam para o enfrentamento presente e futuro das crises ambientais e civilizatórias que vêm assolando nosso planeta e ameaçando a futuro na terra.

A intenção precípua deste trabalho consiste em investigar a percepção que os jovens, inscritos no Programa Projovem de Franca (SP), têm a respeito do meio ambiente, e, prepará-los para o enfrentamento dos problemas ambientais do presente direcionando-os para a aquisição de conhecimentos com vistas a prevenções futuras.

Para realização deste trabalho optou-se pela pesquisa-ação, conforme Thiollent (1986, p. 14), compreendida como "[...] uma metodologia derivada da pesquisa social com base empírica, concebida e realizada em estreita associação com uma ação ou a resolução de um problema coletivo", onde os pesquisadores e os participantes representativos da situação ou problema estão envolvidos de modo cooperativo ou participativo.

O local escolhido para o desenvolvimento da pesquisa-ação foi 0 Programa Projovem Adolescente na cidade de Franca(SP), sediado na instituição filantrópica Obras Assistenciais Dr. Ismael Alonso Y Alonso (IMA), destinado à assistência de jovens de 15 a 17 anos socialmente vulneráveis. Os objetivos desta pesquisa são: observar a atual percepção que estes jovens têm em relação ao meio ambiente; incluir o tema ambiental no seu cotidiano; compartilhar conhecimentos; atitudes e ações sobre Educação Ambiental, que visam melhores entendimentos para o enfrentamento dos problemas ambientais. Também buscou aguçar uma compreensão crítica sobre assuntos relacionados ao meio ambiente e sua coletividade.

\section{A PESQUISA-AÇÃO}

A pesquisa foi realizada em um projeto socioeducativo já existente na cidade de Franca (SP). Criado em 2005 e reestruturado em 2008, o Programa Projovem Adolescente é um dos quatro eixos do Programa Nacional de Inclusão de Jovens. Este programa é destinado aos jovens de 15 a 17 anos que são membros das famílias beneficiárias do Programa Bolsa Família ou em situação de risco social. Sua coordenação é de responsabilidade do Ministério de Desenvolvimento Social e Combate a Fome - (MDS) e oferece oportunidades socioeducativas para criar condições de inserção, reinserção e permanência dos jovens no sistema educacional. 
Na cidade de Franca (SP), o Programa Projovem Adolescente está vinculado ao CRAS Zona Norte e sediado na instituição filantrópica "Obras Assistenciais Dr. Ismael Alonso Y Alonso - (IMA)". Neste ambiente recebem toda a infraestrutura, a alimentação, as oficinas oferecidas e o transporte para todos os alunos. Para tanto, recebem incentivos financeiros dos Governos Federal e Municipal além de contar com verbas de doções comunitárias.

O objetivo da pesquisa-ação consiste em investigar a percepção que os jovens têm a respeito do meio ambiente, prepará-los para o enfrentamento dos problemas ambientais do presente e transmitir conhecimentos para prevenções futuras.

Para tanto seria necessário observar um grupo de jovens por um período, incluir a temática ambiental no cotidiano destes jovens; incentivar e aprofundar o debate socioambiental com foco em políticas públicas; proporcionar atitudes responsáveis que permitissem a realização de ações concretas para a melhoria da sua qualidade de vida, da coletividade e do meio ambiente; incentivar, promover e divulgar conceitos sustentáveis.

\section{PROCEDIMENTOS METODOLÓGICOS APLICADOS}

Em todas as aulas, a participação foi o cerne da aprendizagem. Participar é compartilhar poder, respeitar ao outro e assegurar igualdade nas decisões. Buscaram-se estratégias que garantia o exercício da autonomia com responsabilidade e com a convicção de que a nossa individualidade se completa na relação com o outro no mundo e a liberdade individual passa pela liberdade coletiva. Também se deu prioridade para a utilização de recursos contemporâneos, atrativos aos olhares destes jovens.

O quadro um apresenta o método aplicado neste projeto de pesquisaação, bem como os objetivos a serem alcançados.

Quadro 1 - Estratégias metodológicas

\begin{tabular}{|c|c|c|}
\hline ESTRATÉGIA & OBJETIVO GERAL & OBJETIVOS ESPECÍFICOS \\
\hline Reflexões filosóficas & $\begin{array}{l}\text { Refletir sobre sua vida } \\
\text { e sua conexão com } \\
\text { meio ambiente. }\end{array}$ & $\begin{array}{l}\text { Conhecer a si mesmo. } \\
\text { (Re)conhecer o quando } \\
\text { dependemos da natureza. }\end{array}$ \\
\hline Base teórica & $\begin{array}{l}\text { Conhecimento e } \\
\text { atualização de dados } \\
\text { legislativos, executivos } \\
\text { e científicos. }\end{array}$ & $\begin{array}{l}\text { Marcos legais. Artigo } 225 \text { da } \\
\text { Constituição Federal de } 1988 \text {. Lei } \\
\text { no } 9.795 \text { de } 27 \text { de Abril de } 1999 . \\
\text { Direitos e deveres dos cidadãos. }\end{array}$ \\
\hline Discussões / debates & $\begin{array}{l}\text { Desenvolvimento de } \\
\text { opiniões críticas. }\end{array}$ & $\begin{array}{l}\text { Desenvolvimento de relações } \\
\text { positivas entre alunos e professor. }\end{array}$ \\
\hline
\end{tabular}




\begin{tabular}{|c|c|c|}
\hline & & $\begin{array}{l}\text { Encorajar o desenvolvimento de } \\
\text { novas ideias. } \\
\text { Manifestação de experiências e } \\
\text { desejos. }\end{array}$ \\
\hline $\begin{array}{l}\text { Vídeos, filmes e } \\
\text { documentários }\end{array}$ & $\begin{array}{l}\text { Atualização e } \\
\text { conhecimento. }\end{array}$ & $\begin{array}{l}\text { Estimular a aprendizagem de } \\
\text { outras maneiras. } \\
\text { Enriquecer conhecimentos } \\
\text { Servir de motivação para os } \\
\text { alunos, levando a um índice de } \\
\text { concentração maior, bem como o } \\
\text { desenvolvimento crítico e cultural. }\end{array}$ \\
\hline Trabalhos em grupo & $\begin{array}{l}\text { Promover diálogos } \\
\text { entre os alunos sobre o } \\
\text { tema. }\end{array}$ & $\begin{array}{l}\text { Promover a cooperação em busca } \\
\text { da aprendizagem contextualizada } \\
\text { e significativa. } \\
\text { Sistematizar o resultado das } \\
\text { discussões, assegurando a } \\
\text { compreensão da estratégia como } \\
\text { uma das etapas da } \\
\text { aprendizagem. } \\
\text { Estimular o trabalho em equipe. }\end{array}$ \\
\hline Visitas técnicas & $\begin{array}{l}\text { Exploração das práticas } \\
\text { estudadas na teoria. }\end{array}$ & $\begin{array}{l}\text { Observar o ambiente real em } \\
\text { pleno funcionamento, além de ser } \\
\text { possível verificar sua dinâmica, } \\
\text { organização e todos os fatores } \\
\text { teóricos implícitos. } \\
\text { Forma de rever os conceitos } \\
\text { teóricos metodológicos e } \\
\text { expressar o diálogo produzido em } \\
\text { sala de aula. } \\
\text { Exercício de fixação e avaliação } \\
\text { do conhecimento. }\end{array}$ \\
\hline
\end{tabular}

Fonte: Elaborado por Lúcia Regina Tanaka Bovo em 30 jan. 2013.

\section{As aulas de educação ambiental}

A primeira aula iniciou-se com a participação de apenas oito alunos e teve como foco principal as devidas apresentações: da pesquisadora, dos participantes e da disciplina de Educação Ambiental e Cidadania. Devidamente apresentados, iniciou-se um bate papo descontraído para estreitar os laços de convivência minimizando as tensões entre as partes. Nesta conversa, foram abordados assuntos referentes ao meio ambiente, seus conhecimentos estudados no ensino formal, as suas percepções sobre o tema e suas ações no cotidiano.

De todos os alunos presentes, apenas um relatou ter aulas sobre meio ambiente na escola, porém não se lembrava do conteúdo dado. Segundo seu relato na íntegra: 
Aluno A: "[...] me lembro sim que tive uma professora que falou sobre meio ambiente, mas faz muito tempo e não me lembro mais o que ela falou."

Disse ainda que já havia passado muito tempo do ocorrido e que o assunto não lhe despertou interesse. O restante disse que sabiam algumas coisas sobre meio ambiente porque viram na televisão.

Aluno B: "[...\} as vezes passa na televisão propaganda sobre a floresta da Amazônia, ou da natura (empresa de cosméticos) que fala sobre meio ambiente."

Perguntado ao grupo o que vem à sua cabeça quando ouve a palavra meio ambiente, a resposta imediata da maioria é de apenas uma palavra: lixo. Também foram citadas as palavras: mato, bicho e reciclagem.

Perguntado se tinham alguma ação ecológica em sua residência ou no seu cotidiano, apenas um relatou que o pai todos os dias desligava a geladeira à noite para economizar energia.

\begin{abstract}
Aluno C: "[...] na minha casa meu pai desliga todos os dias a geladeira na hora de dormir e só liga no dia seguinte de manhã. Ele faz isso pra economizar a energia e diminuir a conta de luz."
\end{abstract}

Ao perceber que os alunos não sabiam o que falar, foi reformulado a pergunta. Desta vez foi perguntado se eles sabiam o que fazer para preservar o meio ambiente. A resposta foi completamente diferente. Todos falaram pelo menos três ação que sabiam para a preservação ambiental. Dentre elas foram: escovar os dentes com a torneira fechada, apagar a luz ao sair do ambiente e não jogar lixo no chão.

A pesquisadora pode confirmar o famoso dito popular que diz que na teoria a prática é outra. Também foi observado que provavelmente todos eles já teriam algum conhecimento sobre o meio ambiente, o que deve ter acontecido provavelmente nas escolas do ensino formal.

Ao final deste primeiro encontro, pesquisadora e os sujeitos da pesquisa traçaram a metodologia do ensino. Ficou estipulado que ao final de cada tema estudado na teoria, fazia-se necessária a demonstração na prática.

Esta conversa inicial serviu de base de dados para a pesquisa. Foi com base nela que se teve uma noção do grau de conhecimento destes jovens sobre o tema e norteou a escolha do conteúdo a ser ministrado nos próximos encontros.

A partir da segunda aula começaram os estudos relacionados ao meio ambiente. Foram proporcionadas as aulas teóricas que embasaram os conceitos, legislação, aplicação no cotidiano, vídeos sobre os temas estudados e ao final o debate em sala. A proposta deste suporte teórico é transmitir conhecimentos necessários para o aprendizado sobre o tema estudado.

Também a partir desta aula, a técnica de observação começou a ser utilizada. Esta técnica foi empregada no intuito de conhecer mais o real do que o 
racional, ou seja, o racional representa o que teoricamente estes jovens sabem sobre a preservação do meio ambiente, já o real representa a ação, ou seja, o que realmente eles fazem para a preservação do meio ambiente.

A observação é uma capacidade não apenas humana, desde que o mundo é mundo. No cotidiano é uma das formas mais usadas para conhecer e compreender pessoas, coisas acontecimentos e situações. É o meio básico de se conseguir informações [...] é o ato de se obter informações para se tomar decisões após o julgamento de uma situação (BRASIL, 1997 p.83 apud PORTES; PORTES, 2009, p. 31).

A primeira ação prática se deu a partir da quinta aula. Foi dado o tema sobre o qual tinham que fazer cartazes para a comemoração do Dia da Água. A turma foi dividida em grupos que discutiram entre si o que fazer, como fazer e que mensagem queriam passar referente à preservação, o consumo e desperdício da água.

Os cartazes foram expostos em pontos estratégicos da Instituição, ao lado dos bebedouros de água, na entrada da instituição, próximos aos banheiros e refeitório. Os autores de cada cartaz informavam para as pessoas ali presentes e interessadas, qual a sua mensagem, o porquê preservar a água e de que maneira podemos contribuir para sua preservação. Coincidentemente, o Dia Mundial da Água se deu numa quarta-feira, dia que a Instituição IMA recebe visitantes de todas as regiões do Brasil. Pelo menos duas mil pessoas passam por lá nos dia de trabalho. As figuras 1 registra a confecção dos cartazes em comemoração ao dia Mundial da Água.

Figura1 - Grupo de alunos elaborando cartazes - Dia Mundial da Água

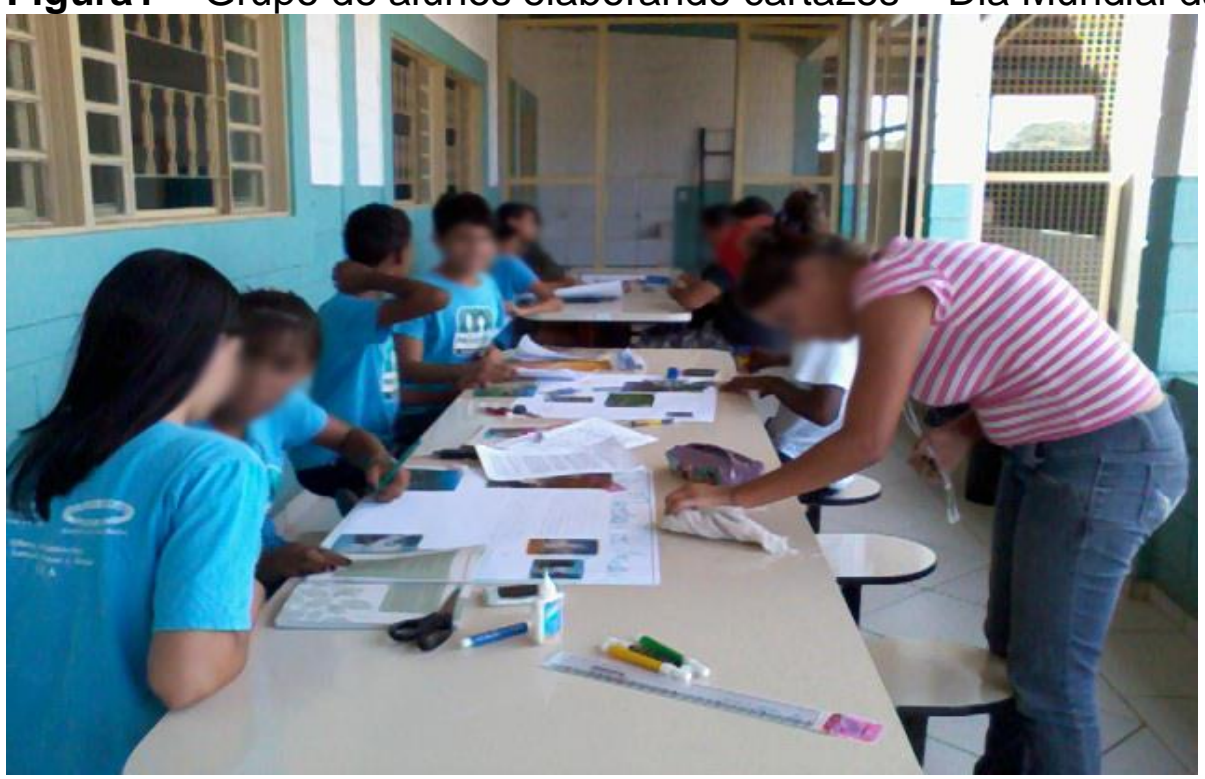

Fonte: Elaborado por Lúcia Regina Tanaka Bovo em 22 mar. 2013

Na sétima aula, saímos da sala de aula e fomos conhecer o bairro onde está situada a Instituição, como demonstra a figura 2. O bairro é um EDUCAÇÃO AMBIENTAL: Pesquisa-ação realizada no Programa Projovem Adolescente de Franca (SP) - pp. 42-55 
condomínio de chácaras residenciais o que facilitou a se tornou bem interessantes às observações feitas pelos alunos. Como exemplo, houve observação sobre os pássaros, a vegetação, o lixo nas ruas, etc., como demonstram os relatos dos alunos.

Aluno A: "Pelas ruas do bairro, deu pra perceber como é feio o lixo espalhado no chão. As pessoas joga tudo no chão. Encontrei copo, garrafas, papel e até restos de comida numa marmitex."

Aluno B: "Vi muitos pássaros diferentes. Eles cantavam. Até um tucano tava comendo no alto de um coqueiro. Achei muito bonito."

Aluno C: "[...] nunca tinha percebido o quanto as árvores eram bonitas. $O$ bairro tem muitas árvores de vários tamanhos. As sombras que elas fazem é muito boa. Sentei debaixo dela e fiquei admirandoa."

Percebe-se nestes relatos o quanto os temas ambientais estão longe da vivência do cotidiano destes jovens. Essa realidade se atribui à trajetória da geração mais novas, nascida em ambientes culturalmente mais urbanizados, esquecendo-se da importância e contemplação da natureza.

Figura 2 - Foto reconhecendo o bairro Recreio Campo Belo

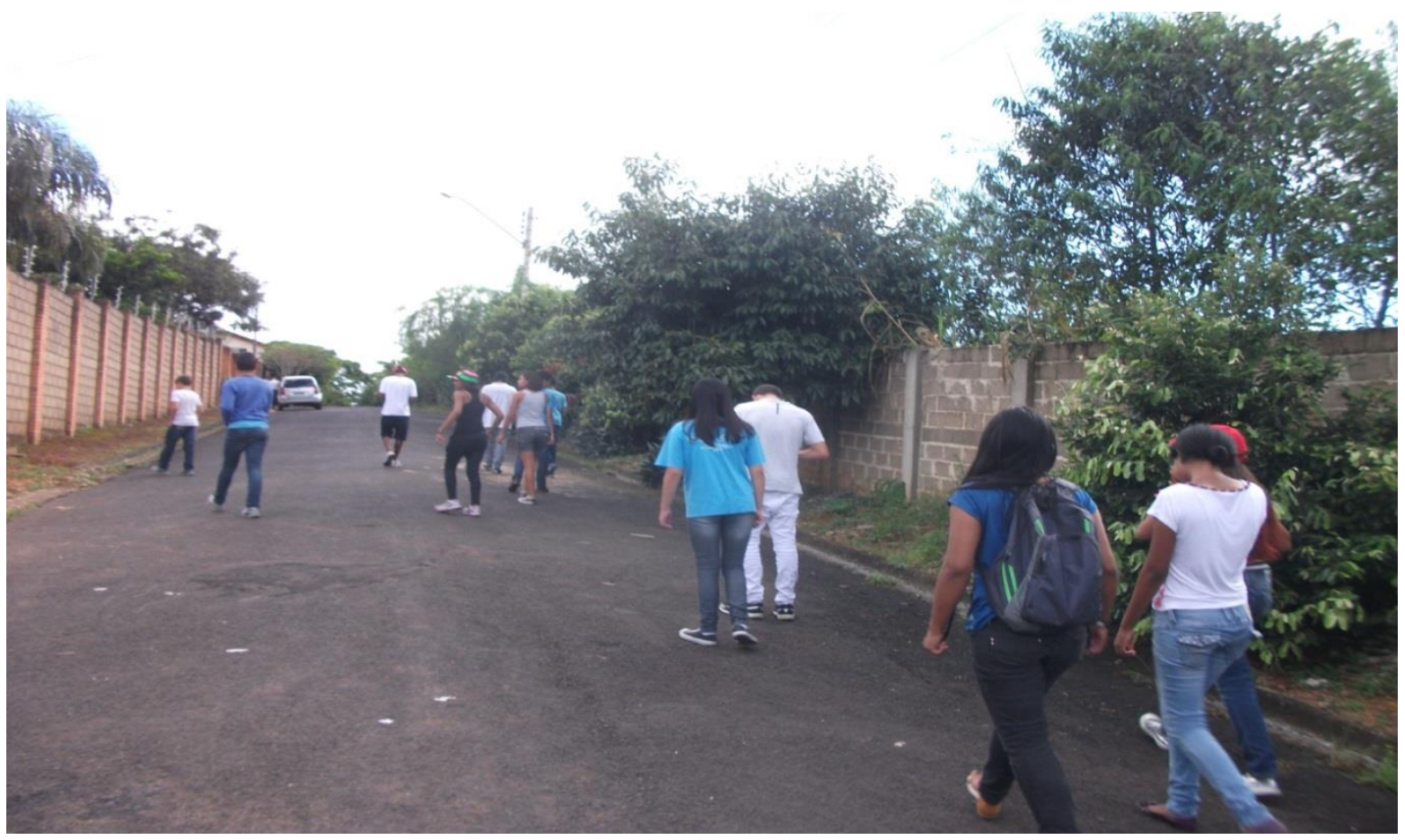

Fonte: Fotografado por Lúcia Regina Tanaka Bovo em 3 Abr. 2013.

Na oitava aula, foram abordados os temas sobre a flora e parte da fauna do Brasil. Para vivenciar a prática, organizou-se uma visita técnica ao Jardim Zoo Botânica da cidade. Fomos recebidos por estagiários que ministraram uma aula de como lidar com a terra, a diferenciação de árvores nativas e exóticas. 
Conhecemos vários tipos de árvores, flores e vegetações, também obtivemos algumas informações sobre animais peçonhentos e alguns insetos.

As últimas cinco aulas foram abordadas temas relativos à preservação da fauna e flora brasileira. Foram incluídos neste contexto filmes relacionados ao meio ambiente, documentários, além de aulas teóricas sobre os temas.

Os trabalhos foram encerrados com a última visita técnica ao Bosque de Ribeirão Preto/SP. Durante o passeio, os alunos puderam conhecer os diversos tipos de animais, identificar quais os animais exóticos, observarem seus comportamentos, sua alimentação, dentre outros.

Chamou a atenção nesta visita, o entusiasmo, curiosidade e as observações dos alunos em cada local visitado. Perguntas eram feitas e respondidas entre o grupo, demonstrando a eficácia das aulas teóricas e a inclusão do assunto entre o grupo.

Figura 3 - Foto- Visita técnica ao Bosque de Ribeirão Preto (SP)

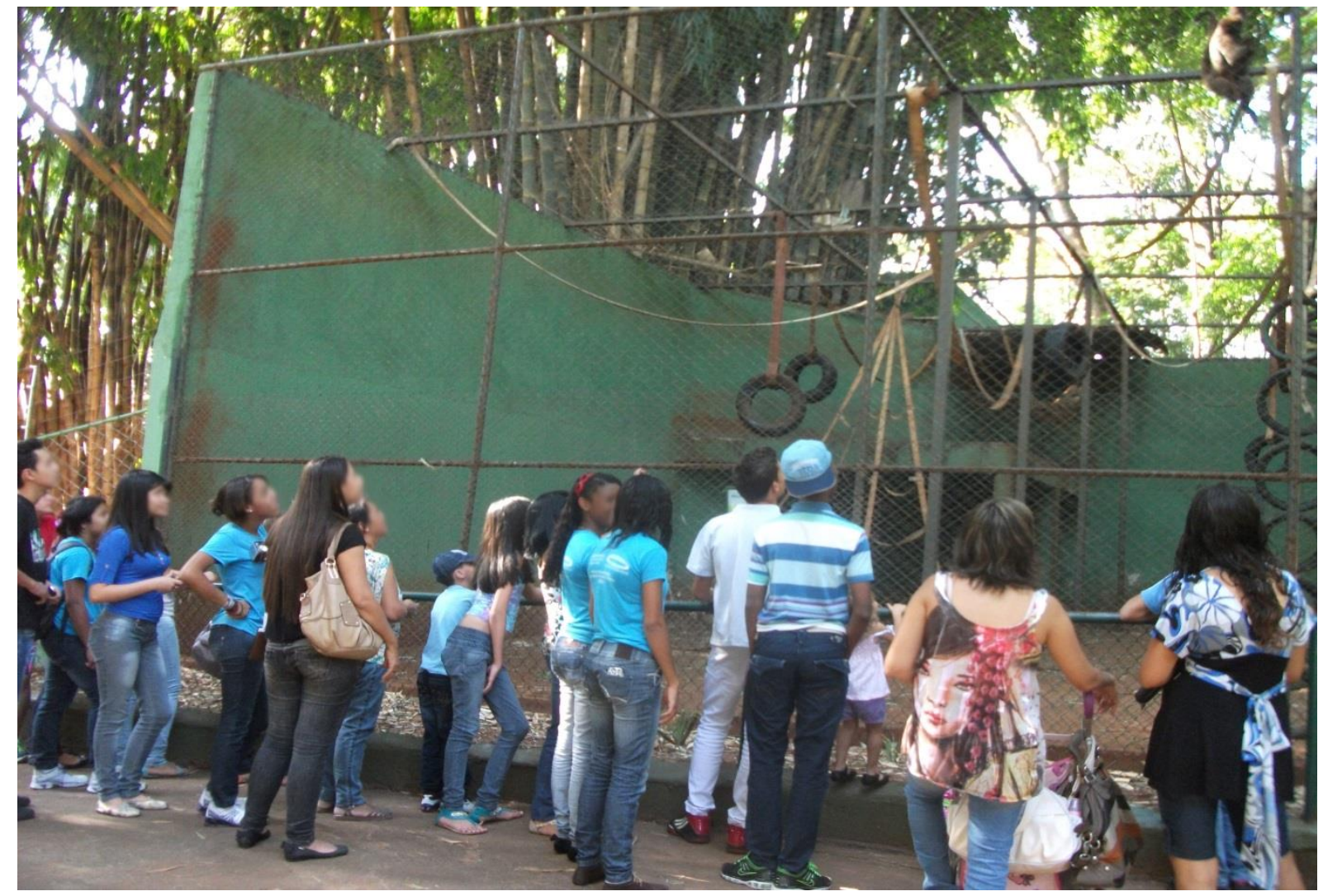

Fonte: Fotografado por Lúcia Regina Tanaka Bovo em 12 ago. 2013.

\section{CONCLUSÃO DA PESQUISA-AÇÃO}


Mesmo com toda infraestrutura oferecida pelo IMA, à instituição encontrava dificuldades para completar a turma e para a retenção de alunos. Dentre os motivos de tal ocorrência, a principal estava relacionada à forma de ingresso de alunos ao instituto, visto que a maioria deles estava matriculada para cumprir a exigências de outros projetos sociais.

O trabalho foi iniciado com um grupo de apenas oito jovens. Inicialmente a falta de conhecimento e a desconfiança sobre o tema logo foram superadas, propiciando um ambiente favorável ao interesse dos alunos pelos temas em discussão.

Em um curto espaço de tempo, novos alunos ingressaram, totalizando dezoito adolescentes com integração unânime em todas as atividades desenvolvidas, expressando suas opiniões sobre os temas discutidos em sala de aula de forma participativa, interagindo e estimulando o pensamento crítico e emancipatório sobre Educação Ambiental.

A metodologia utilizada possibilitou a implantação de um processo coletivo de produção e compartilhamento de saberes. Também permitiu por parte da pesquisadora, observar o comportamento destes jovens no decorrer das atividades desenvolvidas, as quais foram devidamente documentadas.

Devido à pequena população de alunos, optou-se por não aplicar questionários individuais, conforme Thiollent (1986, p. 65) para não comprometer os resultados da pesquisa, assim diz o autor:

$\mathrm{Na}$ pesquisa-ação nem sempre são aplicados questionários codificados, pois quando a população é de pequena dimensão e sua estruturação em grupos permite a fácil realização de discussões, é possível obter informações principalmente de modo coletivo, sem administração de questionários individuais.

A técnica de observação permitiu à pesquisadora, no início do projeto, identificar o grau de conhecimento e a relação dos jovens participantes com o meio ambiente e ao final formular suas conclusões.

necessário:

Ao término deste trabalho, algumas considerações fazem-se

1. Quanto à baixa percepção dos jovens brasileiros em relação ao meio ambiente: no decorrer do trabalho ficou evidente que estes jovens ainda não despertaram para as questões ambientais da contemporaneidade. Diante do fato de que os desastres ambientais vêm se intensificando a cada ano e as perdas sociais, econômicas e ambientais são evidenciadas, a baixa percepção dos jovens torna-se um grande empecilho para a resolução e/ou amenização dos problemas socioambientais.

2. Motivos da baixa percepção: Os principais motivos da baixa percepção dos jovens sobre os assuntos relacionados ao meio ambiente detectados neste trabalho foram: a urbanização impregnada em seu modo de vida; a desinformação e falta de estímulos para a aprendizagem e o processo de 
ensino descontinuado no ensino formal para essa faixa etária (ensino médio e superior).

Como possíveis soluções para os problemas detectados, sugere-se a Educação Ambiental cidadã transformadora como um instrumento da reprodução social.

Inspirado nas categorias de representações ambientais de Sauvé (2000) inscritos no quadro um, os problemas detectados durante as observações iniciais foram:

1 - O ser humano desassociado da natureza: Os jovens inscritos no projeto não se interagia com a natureza, não tinham hábitos de observação, tampouco de preservação da mesma. Por estarem inseridos exclusivamente em um ambiente urbanos, sequer tinham consciência da importância do meio ambiente e sua relevância. Como forma de mudar este cenário, foram convidados a fazer visitas técnicas e observações ecológicas durante todo o projeto. Destacam-se aqui as observações feitas na oitava aula, onde fizeram o reconhecimento do bairro no entorno da escola: a quantidade de lixo espalhados pelas ruas do bairro; a ausência de pássaros na pequena mata nativa existente agravado pela concorrência de árvores frutíferas não nativas inseridas em áreas privadas; a apreciação das belezas naturais existentes no bairro, como as árvores, as frutas, diversas espécies de pássaros; o ar puro que respiraram, entre outros.

2 - O ser humano usando recursos naturais de forma irracional: os jovens não percebiam que tudo que necessitamos para nossa sobrevivência é pertinente ao meio ambiente. Não compreendiam da nossa dependência ambiental. Não tinham consciência do quanto os seres humanos necessitam dela para suprir suas necessidades básicas e tampouco de sua importância como fornecedora dos recursos. Para atingir os objetivos propostos, foram abordados assuntos sobre sustentabilidade e a importância de reduzirmos o consumo exagerado de recursos naturais, instigando-os a pensar de maneira consciente as consequências do consumismo sobre o meio ambiente.

3 - O se humano têm efeito negativo no ambiente e a vida está ameaçada: Os jovens pesquisados não tinham consciência sobre os impactos negativos de suas ações sobre o meio ambiente. Não tinham consciência e conhecimento da importância destas ações sobre de preservação ambiental. Seu comportamento não demonstrava nenhum tipo de pensamento ecológico. Para mudar este quadro foi implantado um desafio que perdurou no curso. Os jovens pesquisados deveriam diariamente se auto perguntar: o que posso fazer hoje para contribuir com o meio ambiente? Esta pergunta proporcionou a estes jovens incluir, a cada dia, uma nova ação ambientalmente correta. Como consequência, aos poucos foi observado pela pesquisadora, mudanças de comportamentos como: redução do uso de copos descartáveis, mudança de atitudes quanto ao lixo em sala de aula, o engajamento nas questões ambientais, inclusive com eles mesmos se questionando em suas ações, entre outros.

4 - O ser humano é individualista e falta compromissos políticos com sua própria comunidade: Os jovens integrantes do projeto não os incluíam nos problemas ambientais, acreditando que o problema é dos outros e não deles. Neste caso, foram EDUCAÇÃO AMBIENTAL: Pesquisa-ação realizada no Programa Projovem Adolescente de Franca (SP) - pp. 42-55 
utilizadas aulas teóricas para demonstrar-Ihes que o meio ambiente é compartilhado por todos, em especial os problemas. Entre várias discussões, os jovens foram encorajados a denunciar e/ou procurar autoridades públicas para que seu direito a um ambiente saudável seja preservado.

Outro ponto de destaque e o diferencial desta pesquisa-ação é sobre os temas das aulas. Todos os temas abordados foram fundamentados com base em legislações vigentes, sendo, portanto, respeitados os direitos e deveres quando aplicáveis. Também a utilização de métodos contemporâneos e tecnológicos como vídeos, filmes, músicas, viagens técnicas, entre outros, que auxiliaram e motivaram a participação e o interesse dos jovens no decorrer da pesquisa, tornando as aulas mais atrativas para essa faixa etária.

Como resultado, observou-se uma relevante mudança na percepção destes jovens, antes sem qualquer ação ambientalmente correta. No decorrer desta pesquisa, este grupo de jovens demonstraram mais interesse sobre a importância dos temas estudados e passaram a adotar mais ações sustentáveis em seu cotidiano.

A conscientização, como princípio da pesquisa-ação em Educação Ambiental, não se refere aos resultados empíricos das ações de investigação e ações educativas, tampouco à aquisição aparente de conhecimentos sobre o ambiente. Refere-se ao processo complexo de reflexão filosófica e política, rumo à construção histórica, pelos sujeitos sociais, de uma sociedade sustentável, ou seja, a práxis social.

Ao longo da pesquisa, foi observado certo amadurecimento nas reflexões e na conduta dos alunos com relação ao meio ambiente. O que pode ser vislumbrado é que suscitaram grandes mudanças de comportamento por parte dos alunos, traduzido pelo aumento do respeito mútuo entre os alunos e o meio ambiente.

E assim, este projeto de Educação Ambiental cidadã e crítica cumpre seu papel como instrumento de transformação social.

\section{CONSIDERAÇÕES FINAIS}

Finalizando este trabalho e não a discussão que permeia este tema, convém ressaltar que, com base nas observações realizadas na pesquisa-ação, foi possível identificar a necessidade de trabalhar intensamente com essa faixa etária em todas as classes sociais, na perspectiva de aguçar os laços entre o homem e o meio ambiente, tornando-os responsáveis pela preservação e conservação da natureza.

Também foi possível a identificação de prováveis indicadores a serem trabalhados em um projeto de Educação Ambiental, não apenas como aquisição de 
conhecimentos, mas como uma ferramenta estratégica para o desenvolvimento da percepção e da sensibilização, para a introdução de ações sustentáveis em seu cotidiano.

Segundo autores como Reigota (1995) e Dias (2000), enfatizam que a Educação Ambiental é um instrumento poderoso de que a sociedade dispõe no momento para recriar valores perdidos ou nunca alcançados antes, capazes de induzir crianças e jovens a perceberem a natureza como um bem comum.

Vale fazer aqui uma observação sobre a forma e o conteúdo ensinando na perspectiva da Educação Ambiental atual. Precisamos de uma Educação Ambiental cidadã e crítica, onde desperte nos seres humanos a integração homem/natureza de forma individual, objetivando a melhoria da coletividade.

Tendo em conta as limitações deste estudo, futuras investigações poderão centrar-se no processo educativo de forma a compreender melhor a processo de instrução da Educação Ambiental no ensino formal.

\section{REFERÊNCIAS}

ABRAMOVAY, M.; CASTRO, M. G. Juventude, juventudes: o que une e o que separa. Brasília, DF: UNRSCO, 2006. v. 1.

ALVES, N. B. A consciência ambiental dos jovens: uma pesquisa com estudantes do nível médio técnico e superior tecnológico. 2013. Dissertação (Mestrado em Administração) - Universidade Federal do Rio Grande do Sul, Porto Alegre, 2013. Disponível em: <www.lume.ufrgs.br/bitstream/handle/10183/76195/000893539.pdf?sequence=1>. Acesso em: 20 jan. 2014.

Barbieri, J. C.; SILVA, D. Desenvolvimento sustentável e educação ambiental: uma trajetória comum com muitos desafios. 2011. Disponível em: <http://gvpesquisa.fgv.br/publicacoes/gvp/o-desafio-da-educacao-ambiental>. Acesso: 15 fev. 2015.

BRASIL. Lei no 9.795, de 27 de abril de 1999. Dispõe sobre a educação ambiental, institui a Política Nacional de Educação Ambiental e dá outras providências. Diário Oficial da União, Poder Legislativo, Brasília, DF, 28 abr. 1999. p. 1. Disponível em: <www.planalto.gov.br/ccivil_03/leis/l9795.htm>. Acesso em: 12 abr. 2014.

. Lei $n^{\circ}$ 8.069, de 13 de julho de 1990. Dispõe sobre o Estatuto da Criança e do Adolescente e dá outras providências. Diário Oficial da União, Poder Legislativo, Brasília, DF, 16 jul. 1990. p. 13563. Disponível em: <http://www.planalto.gov.br/ccivil_03/leis/l8069.htm>. Acesso em: 12 abr. 2014.

BRUNDTLAND, Gro Harlem. Nosso futuro comum: Comissão Mundial sobre Meio Ambiente e Desenvolvimento. 2. ed. Rio de Janeiro: Ed. FGV, 1991.

CARVALHO, I. C. M. Educação ambiental: a formação do sujeito ecológico; 6. ed. São Paulo: Cortez; 2012. 
Conferência intergovernamental sobre educação ambiental. UNESCO. Declaração da Conferência Intergovernamental sobre Educação Ambiental. Tbilisi: Unesco, 1977. Disponível em: <www.ambiente.sp.gov.br/wpcontent/uploads/cea/Tbilisicompleto.pdf>. Acesso em: 5 mai 2013.

DEMO, P. N. Metodologia científica em ciências sociais. 2. ed. São Paulo: Atlas, 1989.

ESTOCOLMO- Ministério do Meio Ambiente. Disponível em: <www.mma.gov.br/estruturas/agenda21/_arquivos/estocolmo.doc>. Acesso em: 28 jun. 2013.

IBGE. Pesquisa Nacional por Amostra de Domicilio 2008. Rio de Janeiro, 2010. Disponível $<$ www.ibge.gov.br/home/estatistica/populacao/trabalhoerendimento/pnad2009/pnad_ sintese_2009.pdf>. Acesso em: 20 jun. 2013.

INSTITUTO CIDADANIA; INSTITUTO HOSPITALIDADE; SEBRAE. Perfil da juventude brasileira. Salvador 2003. Brasília, DF, 2014 Disponível em: $<$ www.fpabramo.org.br/uploads/perfil_juventude_brasileira.pdf>. Acesso em: 19 set. 2014.

LAKATOS, E. M.; MARCONI, M. A. Técnicas de pesquisa: planejamento e execução de pesquisa. 7. ed. São Paulo: Atlas, 2008.

LEFF, E. Epistemologia ambiental. São Paulo: Cortez, 2001.

Discursos sustentáveis. São Paulo: Cortez, 2010.

LOUREIRO, C. F.; LAYRARGUES, P. P. Educação ambiental nos anos 90: mudou, mas nem tanto. Políticas Ambientais, Rio de Janeiro, n. 9, v. 25, p. 6-7, 2001.

MÉSZÁROS, I. Para além do capital. Campinas: Boitempo, 2002

Projovem adolescente: traçado metodológico. Brasília, DF, 2009. Disponível em: < http://www.mds.gov.br/assistenciasocial/sou-gestor-de-assistenciasocial/projovem-adolescente/cadernos-projovem-

adolescente/Tracado\%20Metodologico.pdf/view?searchterm=tra\%C3\%A7ado\%20m etodol\%C3\%B3gico>. Acesso em: 14 jan. 2013.

MINISTÉRIO DO MEIO AMBIENTE. Conceitos de Educação Ambiental. Disponível em: http://www.mma.gov.br/educacao-ambiental/politica-de-educacaoambiental. Acesso em: 16 jan. 2014.

ONU. Declaração do Rio sobre meio ambiente e desenvolvimento. Rio de Janeiro. 1992. Disponível em: <www.onu.org.br/rio20/img/2012/01/rio92.pdf>. Acesso em: 3 jun. 2013.

PALMA, I. R. Análise da percepção ambiental como instrumento ao planejamento da educação ambiental. 2005. 67 f. Dissertação (Mestrado em Engenharia), Universidade Federal do Rio Grande do Sul, Porto Alegre, 2005.

REIGOTA, M. Meio ambiente e representação social. São Paulo: Cortez, 1995. 
. O que é educação ambiental? 2 ed. São Paulo: Brasiliense, 2009.

SAUVÉ, L. Uma cartografia das correntes em educação ambiental. In: SATO, M.; CARVALHO, J. (Org.) Educação ambiental pesquisa e desafio. Porto Alegre: Artmed, 2005.

SECRETARIA NACIONAL DA JUVENTUDE. Agenda juventude Brasil: pesquisa nacional sobre perfil e opinião dos jovens brasileiros. 2013. Disponível em:<www.brasil.gov.br/cidadania-e-justica/2014/02/agenda-juventudebrasil.epub/view>. Acesso em: 20 set. 2014.

SILVA, C. A. F., Retratos da juventude brasileira: análises de uma pesquisa nacional. São Paulo: Fundação Perseu Abramo/Instituto Cidadania, 2005. Disponível em: <www.scielo.br/scielo.php?script=sci_arttext\&pid=S010320702005000200020 >. Acesso em: 20 jul. 2013.

SORRENTINO, M. De Tbilisi a Tessaloniki, a educação ambiental no Brasil. In: JACOBI, P. et al. (Org.). Educação, meio ambiente e cidadania: reflexões e experiências. São Paulo: SMA, 1998.

THIOLLENT, M. Notas para o debate sobre pesquisa-ação. In: BRANDÃO, C. (Org.). Repensando a pesquisa participante. São Paulo: Brasiliense, 1984.

. Metodologia da pesquisa-ação. 2. ed. São Paulo: Cortez, 1986.

TOMAZELLO, M. G. Parâmetros curriculares nacionais e educação ambiental:

educação para a cidadania? Educação: Teoria e Prática, Rio Claro, n.16-17, p. 110, 2001.

TOZONI-REIS, M. F. C. Pesquisa-ação: compartilhando saberes; pesquisa e ação educativa ambiental. In: FERRARO JUNIOR, L. A. (Org.) Encontros e caminhos: formação de educadoras(es) ambientais e coletivos educadores. Brasília, DF: MMA : Diretoria de Educação Ambiental, 2005.

VASCONCELLOS, H. S. R. A pesquisa-ação em projetos de educação ambiental. In: PEDRINI, S. G. (Org). Educação ambiental: reflexões e práticas contemporâneas. 3. ed. Petrópolis: Vozes, 1997 


\title{
EDUCAÇÃO PARA A SUSTENTABILIDADE: Uma proposta de ações para a conscientização da população sobre processo de coleta de lixo reciclável
}

\author{
LEAL, Andréia Cristina de Britto \\ Mestranda em Desenvolvimento Regional \\ Centro Universitário Municipal de Franca - Uni-FACEF \\ sadeiabr@yahoo.com.br \\ CARVALHO NETO, Silvio \\ Doutor em Administração pela USP \\ Centro Universitário Municipal de Franca - Uni-FACEF \\ silvio@facef.br \\ CÂMARA, Naiá Sadi \\ Doutora em Linguística e Língua Portuguesa pela UNESP \\ Centro Universitário Municipal de Franca - Uni-FACEF \\ naiasadi@gmail.com
}

\section{INTRODUÇÃO}

Há 50 anos, o terreno cinzento e arenoso da Lua tomara a forma de uma pegada humana, em meio a um cenário conturbado resultante do período da Guerra Fria. A tecnologia desenvolvida pelos governos na corrida armamentista, entre os anos 1947 a 1989, foi absorvida pelo cidadão comum e proporcionou um avanço sem precedentes na história humana. Contudo, esse avanço tecnológico foi um dos fatores que permitiu que houvesse uma explosão populacional, o que gerou um significativo aumento na geração de lixo no planeta Terra, fato que ainda provoca reflexões profundas no século XXI quanto à sustentabilidade da vida humana, a longo prazo.

A questão que parece ainda insolúvel é com relação ao que tem sido feito a respeito das observações de fragilidade do planeta Terra com relação à essa sustentabilidade.

No século XX, as décadas de 60, 70 e 80 foram marcadas por movimentos ambientalistas e agentes motivadores da paz. Surgiram, neste período, grupos independentes, organizações não governamentais com o objetivo de preservar o meio ambiente, como a canadense Greenpeace e a suíça WWF ("World Wide Fund For Nature" ou "Fundo Mundial para a Natureza"), atualmente, presentes e atuantes em diversos países do globo, financiando projetos e promovendo educação ambiental. 
Especificamente, com relação à produção de lixo, nota-se que a produção de resíduos sólidos urbanos é volumosa e preocupante. Na década de 90 , Barciotte (1994) retrata, de forma histórica, o problema causado pelo lixo como sendo ameaçador para o bem-estar do ser humano. Relata como era o tratamento do lixo residencial nos primórdios de grandes cidades como São Paulo e Rio de Janeiro. Em São Paulo, o lixo, composto em sua maior parte por restos de alimentos, era inicialmente coletado por chacareiros para alimentar suas granjas. Posteriormente, foram contratados carroceiros para coletar o lixo, já que os chacareiros passaram a preferir outros meios de coleta, como os resíduos de restaurantes, por exemplo. Na cidade do Rio de Janeiro, inicialmente, os escravos eram responsáveis por eliminar das vistas dos nobres, os dejetos malcheirosos. Em ambos os casos, não havia tratamento para os resíduos na sua destinação final, eram apenas amontoados em locais distantes das aglomerações humanas em forma de lixões como se observa em inúmeras comunidades até hoje.

O fato de distanciar-se do lixo levando-os para locais inabitados, configura o que bem foi retratado no filme de curta metragem, intitulado "Ilha das Flores", produzido por Jorge Furtado em 1989 e, citado por Barciotte (1994). O curta descreve o caso da llha das Flores, onde os resíduos urbanos da cidade de Porto Alegre, Estado do Rio Grande do Sul, eram despejados os restos de alimentos, que eram descartados da alimentação dos porcos pelos produtores da região, em seguida, eram colocados à disposição de grupos de pessoas famintas, às quais, tinham cinco minutos para selecionar o que poderia ter restado de alimento.

Os exemplos históricos de São Paulo e Rio de Janeiro também mostram como o problema de coleta de lixo nas cidades merece, há tempos, atenção especial do setor público. Um dos procedimentos que foram instituídos pelos setores governamentais com relação à preocupação ambiental e de coleta de lixo foi a "Coleta Seletiva de lixo".

De acordo com Ministério do Meio Ambiente do Brasil (MMA, 2019), Coleta Seletiva é o resultado da separação do lixo, primeiramente, dividindo-o em resíduos e rejeitos, em seguida, os resíduos secos são novamente separados dos resíduos úmidos e classificados conforme sua composição e, por último, disponibilizados para coleta.

O processo de Coleta Seletiva é importante porque cada tipo de resíduo tem o seu processo próprio de reciclagem, e na medida em que vários tipos de resíduos sólidos diferentes são misturados na mesma remessa de coleta, a reciclagem desses processos separadamente se torna mais cara ou mesmo inviável, pois se torna mais difícil separar os distintos resíduos de acordo com sua constituição ou composição. E é por isso que a Política Nacional de Resíduos 
Sólidos estabeleceu que a coleta seletiva nos municípios brasileiros deve permitir, no mínimo, a segregação entre resíduos recicláveis secos e rejeitos orgânicos ${ }^{1}$.

O Ministério do Meio Ambiente (MMA, 2019) aponta que as formas mais comuns de coleta seletiva existentes atualmente no Brasil são a coleta porta-aporta, que pode ser realizada tanto pelo prestador do serviço público de limpeza e manejo dos resíduos sólidos (público ou privado) quanto por associações ou cooperativas de catadores de materiais recicláveis e a coleta por Pontos de Entrega Voluntária (PEVs). Deste modo, a coleta porta-a-porta, é aquela em que um veículo passa em frente às residências e comércios recolhendo todos os resíduos que foram separados pela população. Já os pontos de entrega voluntária consistem em locais situados estrategicamente próximos de um conjunto de residências ou instituições para a entrega dos resíduos segregados pela população e como posterior coleta pelo poder público.

A questão do lixo e da coleta seletiva ainda é um problema atual e que também vem sendo discutido nos estudos que envolvem os Objetivos de Desenvolvimento Sustentável da ONU (2015), "um plano de ação para erradicar a pobreza, proteger o planeta e garantir que as pessoas alcancem a paz e a prosperidade: a Agenda 2030". Em setembro de 2015, na cúpula da ONU em Nova York, líderes mundiais acordaram medidas que provocam reflexões e mudanças de comportamento e atitude concatenados em um conjunto de 17 Objetivos de Desenvolvimento Sustentável (ODS).

Destacamos os objetivos 3 (Saúde e Bem-Estar), 4 (Educação de Qualidade), 10 (Redução das Desigualdades), 11 (Cidades e Comunidades Sustentáveis) e 12 (Consumo e Produção Responsáveis), pois entendemos que seriam contemplados na proposta de ações concernente ao processo de tratamento dos resíduos sólidos urbanos.

Conforme a Política Nacional de Resíduos Sólidos (PNRS), a implantação da coleta seletiva é obrigação dos municípios e nos planos de gestão integrada de resíduos sólidos dos municípios devem constar as metas referentes a esse tipo de coleta seletiva. Cada município é responsável por estabelecer seu processo de coleta seletiva e divulgar à população. No entanto, observa-se que a população, em geral, desconhece as informações divulgadas pelo poder público, com relação aos processos de coleta seletiva, e até mesmo com relação ao próprio conceito deste procedimento de coleta.

\footnotetext{
${ }^{1}$ Os resíduos recicláveis secos são compostos, principalmente, por metais (como aço e alumínio), papel, papelão, tetrapak, diferentes tipos de plásticos e vidro. Já os rejeitos, que são os resíduos não recicláveis, são compostos principalmente por resíduos de banheiros (fraldas, absorventes, cotonetes...) e outros resíduos de limpeza. Há, no entanto, os resíduos orgânicos, que consistem em restos de alimentos e resíduos de jardim (folhas secas, podas...). Os resíduos orgânicos não devem ser misturados com outros tipos de resíduos, para que não prejudiquem a reciclagem dos resíduos secos e para que os resíduos orgânicos possam ser reciclados e transformados em adubo de forma segura em processos simples como a compostagem.
} 
Partimos da premissa de que a questão de educação ambiental é fundamental para o bom andamento da coleta de resíduos nas cidades, e portanto, diante desse cenário, este artigo procura apresentar um estudo exploratório sobre a educação ambiental para a coleta de lixo, estabelecer uma proposta de ações que possam ser tomadas para que haja uma conscientização ambiental e de cidadania em termos dos procedimentos da coleta de lixo, procurando responder à seguinte questão de pesquisa: quais ações podem ser tomadas para que aconteça uma conscientização ambiental e de cidadania em termos dos procedimentos da coleta de lixo.

O artigo está estruturado de forma a apresentar, primeiramente, os conceitos de Desenvolvimento Sustentável (DS) e os problemas enfrentados na Educação Ambiental (EA). Na sequência, procura-se apresentar a importância de medidas de educação para a sustentabilidade e suas consequências para o desenvolvimento de cidades sustentáveis como descrito na Agenda 2030, na seção intitulada como "Cidades e Comunidades Sustentáveis", especificamente na subdivisão que aborda a "gestão de resíduos municipais". Por fim, como exemplo, será apresentada uma situação problema de conscientização e uma proposta de ações práticas de educação ambiental, quanto aos procedimentos de coleta de lixo na cidade de Franca, interior do Estado de São Paulo.

O método deste trabalho é exploratório, baseado principalmente na busca de dados secundários, por meio de pesquisa bibliográfica e documental (CHIZZOTTI, 2000).

O trabalho propõe um estudo bibliográfico da educação ambiental em torno da coleta de lixo em Franca-SP, cidade reconhecida por seu, outrora, apogeu no setor calçadista, pois concentra sua mão de obra na produção de calçados masculino, e representa uma tímida renda per capita, em contrapartida, altos níveis de indicadores sociais.

\section{DESENVOLVIMENTO SUSTENTÁVEL}

Para trabalhar o conceito de desenvolvimento no sentido macro, os economistas Delfim Neto e Ikeda (2009) explicam de forma clara os mecanismos que uma economia se utiliza, na tentativa de se produzir crescimento com foco no desenvolvimento econômico, esperando assim que o restante necessário para o real desenvolvimento ocorra de forma natural. Porém a economia brasileira, assim como a do restante do globo, está inserida numa trama interdependente, sensível às crises na economia internacional, resultando em altos e baixos nos gráficos da economia interna compatíveis com o eletrocardiograma de um país enfartado. Em suma, os autores revelam a ingenuidade do poder público em não considerar os fatores sociais na busca pelo desenvolvimento. 
Desenvolvimento local ou regional, segundo Lima e Ascenzi (2017), "é um processo de mudança e de crescimento estrutural, gerado a partir da utilização do potencial de desenvolvimento existente no território, com propósito de incrementar o bem-estar da população". Neste sentindo, para que haja um desenvolvimento endógeno, a variação depende da mudança de comportamento e consequente colaboração do maior número possível de habitantes de uma cidade, formando assim uma comunidade cooperativa, através da participação da população, buscando equidade e utilização dos privilegiados recursos disponíveis no local para desempenhar a sustentabilidade, contemplando assim o tripé da endogeneidade.

Na visão de Sachs (1986), entretanto, o desenvolvimento local tem que ocorrer acoplado ao desenvolvimento Sustentável, nomeado por "ecodesenvolvimento", sendo uma visão holística da relação desenvolvimento e meio ambiente. Conforme aponta Costa Lima (2003), Sachs, ao formular a noção de Ecodesenvolvimento, propunha uma estratégia multidimensional e alternativa de desenvolvimento que articulava promoção econômica, preservação ambiental e participação social. (COSTA LIMA, 2003)

Esta proposta de Sachs foi enfraquecida pelo Relatório Brundtland da ONU, lançado em 1987, pois apresentava práticas sustentáveis, ainda que de forma abrangente, que não se contrapunham à evolução econômica e tecnológica daquele período. A ONU (Organização das Nações Unidas) precisava abrandar o discurso socialista para aumentar a adesão dos países mais ricos do mundo, e consequentemente, maiores causadores da degradação ambiental.

O texto contido no Relatório Brundtland tornou-se mais intencional e didático na elaboração da Agenda 2030 e seus 17 Objetivos, que foram subdivididos em 169 metas, delimitando as ações para o Desenvolvimento Sustentável, adotados pela Cúpula das Nações Unidas, em 2015.

Os Objetivos de Desenvolvimento Sustentável da ONU se interligam com as respectivas metas individuais, facilitando a compreensão e a promoção de ações afirmativas. O documento como um todo possui um objetivo em comum ambicioso e a longo prazo. É positivo em diversos aspectos, em especial a simplificação de assuntos complexos e a conscientização da necessária cooperação de todos, além de buscar um equilíbrio do desenvolvimento sustentável nas três dimensões: econômico, social e ambiental.

O desenvolvimento sustentável direcionado para políticas de conscientização e aplicação dos Planos de Resíduos Sólidos, nas ODS corrobora para atingir, direta ou indiretamente, algumas das metas dispostas nos seguintes objetivos da Agenda 2030: 3, 4, 10, 11 e 12, que são, respectivamente subintitulados: "(3) Assegurar uma vida saudável e promover o bem-estar para todos, em todas as idades"; "(4) Assegurar a educação inclusiva e equitativa e de qualidade, e promover oportunidades de aprendizagem ao longo da vida para 
todos"; "(10) Reduzir a desigualdade dentro dos países e entre eles"; "(11) Tornar as cidades e os assentamentos humanos inclusivos, seguros, resilientes e sustentáveis" e "(12) Assegurar padrões de produção e de consumo sustentáveis." (ONU, 2015).

Cada um desses cinco objetivos pode ser explorado e relacionado com o objeto deste trabalho e as propostas de ações no âmbito municipal. O objetivo 3.assegurar uma vida saudável e promover o bem-estar para todos, em todas as idades- está ligado com a divulgação dos conceitos de minimização do consumo e da conscientização do descarte correto de recicláveis, e também com o incentivo à elaboração de arranjos residenciais e aos movimentos de pressão popular para criação de políticas públicas para eliminar os lixões substituindo-os em aterros sanitários.

A importância do tratamento do lixo para a Saúde Pública é evidenciada nesse ODS 3, que busca assegurar uma vida saudável e promover o bem-estar para todos, em todas as idades. Apesar do progresso recente na redução de mortalidade e controle das enfermidades, as doenças crônicas e aquelas resultantes de desastres continuam a ser os principais fatores que contribuem para a pobreza e para a privação dos mais vulneráveis. Atualmente, $63 \%$ de todas as mortes do mundo provêm de doenças não transmissíveis, principalmente cardiovasculares, respiratórias, câncer e diabetes (ODS3, 2019). A ONU estima que as perdas econômicas para os países de renda média e baixa provenientes destas doenças ultrapassarão US\$ 7 trilhões até 2025.

Os ODS se interligam em torno das metas propostas. O Objetivo 10 tem como base reduzir a desigualdade dentro dos países e entre eles, difundindo informações acerca da importância socioambiental dos catadores de lixo, que atuam de maneira informal na maioria dos casos, promovem a limpeza urbana e possibilitam para que haja descarte correto de recicláveis. Fica claro o papel social dos catadores de lixo e a oportunidade de formalizar essa profissão promovendo inclusão no mercado de trabalho formal e assalariado.

A ONU observa (ODS10) que o mundo é mais desigual hoje do que em qualquer momento recente da história desde meados do século XX. A desigualdade de renda e na distribuição da riqueza dentro dos países tem disparado, incapacitando os esforços de alcance dos resultados do desenvolvimento e de expansão das oportunidades e habilidades das pessoas, especialmente dos mais vulneráveis. Essa desigualdade é um problema global que requer soluções integradas e a visão estratégica deste objetivo se constrói sob o objetivo da erradicação da pobreza em todas suas dimensões, na redução das desigualdades socioeconômicas e no combate às discriminações de todos os tipos.

Com relação ao ODS 11, seu propósito é tornar as cidades e os assentamentos humanos inclusivos, seguros, resilientes e sustentáveis, com a proposta de políticas públicas de valorização do desenvolvimento sustentável, 
facilitando a prática de ações contidas nos planos municipais de resíduos sólidos (PMRS) com a participação incentivada da população. Esse objetivo é intimamente ligado ao objetivo 12, de assegurar padrões de produção e de consumo sustentáveis, propondo parcerias entre empresas público e privadas para capacitar a todos os colaboradores e seus familiares a respeito de atitudes de consumo sustentáveis. Ambos reforçam o foco das ODS no desenvolvimento sustentável.

A agenda das ODS da ONU (ONU, 2015) aponta que, em 2014, 54\% da população mundial vivia em áreas urbanas, com projeção de crescimento para $66 \%$ em 2050, e que, em 2030, é estimada a existência de 41 megalópoles com mais de 10 milhões de habitantes no mundo. Considerando que a pobreza extrema muitas vezes se concentra nesses espaços urbanos, as desigualdades sociais acabam sendo mais acentuadas e a violência se torna uma consequência das discrepâncias no acesso pleno à cidade, deste modo, a transformação dos espaços urbanos é essencial para que o desenvolvimento sustentável seja alcançado.

O tema de gestão de resíduos sólidos e saneamento está incluído nas metas do ODS 11, sendo as mais relacionadas: 1) até 2030, reduzir o impacto ambiental negativo per capita das cidades, inclusive prestando especial atenção à qualidade do ar, gestão de resíduos municipais e outros; e 2) apoiar relações econômicas, sociais e ambientais positivas entre áreas urbanas, periurbanas e rurais, reforçando o planejamento nacional e regional de desenvolvimento.

\subsection{Educação Ambiental para Coleta de Lixo}

A ONU, na descrição da agenda, declara que "os vínculos e a natureza integrada dos Objetivos de Desenvolvimento Sustentável são de grande importância para assegurar que o propósito da nova Agenda seja realizado." (ONU, 2015) Neste sentido, os ODS apontam que a realização da Agenda 2030 é crucial para que a vida de todos seja beneficiada com o bem-estar comum e o mundo seja transformado para melhor. Deste modo, a integração dos ODS reforça o destaque da educação no processo de fortalecimento das cidades sustentáveis.

O ODS 4 tem como propósito assegurar a educação inclusiva, equitativa, de qualidade e promover oportunidades de aprendizagem ao longo da vida para todos. Seu intuito é proporcionar oportunidades distintas para que informações pertinentes de educação ambiental atinja o maior número de pessoas, de diferentes classes sociais, traduzir a tecnicidade de documentos para uma linguagem mais acessiva, visual, melhor compreensível e próxima da realidade de jovens e adultos utilizando-se de transmídia, como exemplo: websites, cartilhas, folders, histórias em quadrinhos (HQ), aplicativos para celulares, redes sociais entre outros. Portanto, a educação tem papel fundamental na conscientização ambiental e das possíveis práticas sustentáveis no âmbito local. 
Nota-se que a sustentabilidade do planeta é reforçada no ODS que trata sobre a educação. Uma das metas do objetivo 4 é:

\begin{abstract}
"garantir, até o ano de 2030, que todos os alunos adquiram conhecimentos e habilidades necessárias para promover 0 desenvolvimento sustentável, inclusive, entre outros, por meio da educação para o desenvolvimento sustentável e estilos de vida sustentáveis, direitos humanos, igualdade de gênero, promoção de uma cultura de paz e não violência, cidadania global e valorização da diversidade cultural e da contribuição da cultura para 0 desenvolvimento sustentável". (ONU, 2015)
\end{abstract}

De modo geral, o conceito de Educação Ambiental (EA) está ligado ao processo educacional que reflete a preocupação com os problemas ambientais, ao mesmo tempo que busca promover a conservação e a preservação dos recursos naturais, bem como a conceituação do termo desenvolvimento sustentável na esfera regional, a fim de integrar a participação da comunidade e fornecer subsídio para gestões públicas. Assim como projetado no texto da comissão da I CNEA Conferência Nacional de Educação Ambiental, idealizada em 1996 e realizada em 1997. (MMA/MEC, 1997)

O trabalho educacional possibilita a conscientização da importância de ações sustentáveis voltadas para o meio ambiente, porém, assim como observado na redação do I CNEA, as propostas de (EA) têm se mostrado frágeis no objetivo final, como exemplo, podemos citar a campanha "Saco é um Saco". Essa campanha foi uma proposta nacional de conscientização para redução do uso de sacolas plásticas do Ministério do Meio Ambiente de 2011, porém, demonstra carência de informações detalhadas e consistentes, não conseguindo promover mudanças de atitudes ou de comportamento na sociedade. O texto da campanha informa a respeito do quão é prejudicial o seu uso, porém não enfatiza as ações alternativas para reduzir ou eliminar o uso do saco plástico.

Um exemplo bem-sucedido de ação coordenada em prol do meio ambiente foi o desafio "World Cleanup Day", proposto inicialmente na Estônia em 2008, que contou com a colaboração de 50 mil pessoas para recolher o lixo espalhado naquele país em apenas 5 horas. O movimento cívico ganhou adeptos pelo mundo e, em setembro de 2018, uniu 18 milhões de pessoas de 157 países que recolheram toneladas de lixo em um total de 36 horas de limpeza do nosso planeta.

A eficácia da educação ambiental pode estar sendo prejudicada pela carência de pesquisa e produções científicas com um público-alvo mais abrangente, pois observa-se uma predominância em instituições de ensino superior. Pressupõese que, se o objetivo é conscientizar o maior número de pessoas para aderir às campanhas e movimentos que provoquem mudanças de comportamento e de consumo, é plausível que esse campo de atuação das pesquisas, bem como de aplicação de ações afirmativas, seja ampliado para $67,3 \%$ da população nacional que ainda não concluiu ou não teve acesso ao ensino superior, pois estudos revelam 
que apenas $32,7 \%$ dos brasileiros possuem nível de superior completo. (PNAD Contínua 2018).

\subsection{Situação problema observada}

Segundo dados do IPEA (2012), a cidade de Franca-SP está inserida em um microuniverso onde apenas "22 milhões de brasileiros têm acesso a programas municipais de coleta seletiva, ou seja, $12 \%$ da população total”, pois possui um Plano Municipal de Resíduos Sólidos (PMRS) dissonante da situação de cidades vizinhas. Porém observa-se que a disponibilidade deste documento para consulta no site da prefeitura, não é suficiente para eliminar os problemas gerados pelo descarte do lixo em locais inapropriados.

O PMRS de Franca-SP descreve as políticas públicas de gestão do lixo urbano e industrial na cidade com linguagem técnica e comunicativa para os entes públicos envolvidos. Observa-se uma carência de informações menos tecnicista com foco na divulgação de práticas sustentáveis para os munícipes. Este pode ser um dos motivos para que os índices de reciclagem de Franca-SP não sejam ainda melhores que o divulgado em 2013 por pesquisas da USP de Ribeirão Preto-SP, o qual indica que Franca-SP recicla $5 \%$ do total de 43,6 mil toneladas de lixo coletado, por mês, pelas maiores cidades da região. Sendo o índice de Franca-SP o melhor e o pior da cidade de São Carlos-SP com 0,61\%.

A pesquisa da professora e diretora da Faculdade de Saúde Pública da USP, Helena Ribeiro, revela que "os municípios precisam adotar uma política de comunicação para as famílias separarem em casa os resíduos a serem reciclados." Afirma ainda que, metade do lixo produzido nas casas resulta em matéria orgânica e a outra metade pode ser reciclado. Quando os resíduos orgânicos são misturados aos resíduos secos, a triagem é dificultada.

\subsection{Proposta de ações de conscientização e divulgação}

Observando o descaso com o lixo reciclável, o desconhecimento por parte da população a respeito da correta separação entre resíduos orgânicos, rejeitos e resíduos secos, surgiu a necessidade de uma ferramenta que explicasse os conceitos de lixo e suas possíveis divisões. Em seguida, pesquisas na internet foram feitas em busca de informações a respeito no site da prefeitura de Franca-SP. Mas outro problema surgiu, fez-se necessário que se resumisse ou até simplificasse as informações técnicas concernentes nos documentos oficiais da gestão pública e da secretaria do meio ambiente.

Na tentativa de expandir o alcance das informações contidas no PMRS, foi elaborado, de forma independente pela autora principal do presente trabalho, um material educativo com os conceitos de resíduos residenciais e a disponibilidade dos 
pontos de coleta de resíduos especiais, conhecidos também por Pontos de Entrega Voluntária (PEV), existentes na cidade de Franca-SP. O material elaborado divide-se em um folder informativo, que pode ser observado nas figuras 1 e 2, e o cartaz projetado para ser impresso em tamanho A1, figura 3, onde é possível identificar pelo bairro em seguida pela cor e saber por fim os horários de coleta seletiva, podendo ser disponibilizado nos pontos de coleta ou PEVs, áreas públicas de grande circulação, empresas de pequeno, médio e grande porte para instruir seus colaboradores entre outros.

Sendo um dos PEVs uma instituição de ensino superior de autarquia municipal e as informações tendo sido extraídas do site da prefeitura, pensou-se em buscar a parcerias dessas organizações para propiciar credibilidade ao material, inicialmente pensado como impresso em folders autoexplicativo e em um cartaz tamanho A1 contendo o mapa da cidade de Franca-SP, para que os munícipes possam visualizar o bairro em que residem de formal visual (em cores) e consequentemente, distinguir os dias de coleta seletiva de resíduos secos dos dias de coleta de resíduos orgânicos, bem como sua correta separação.

Ao contatar a instituição de ensino superior, surgiu o incentivo para produção deste trabalho acadêmico de forma que o modelo proposto possa ser copiado e expandido para outras cidades com características semelhantes.

Outras ideias surgiram como a possível pulverização dessas informações em transmídia, ou seja, disponibilizar o conteúdo educativo e informativo em diversos mecanismos de comunicação, diversificando o público-alvo, como: website, página em redes sociais, aplicativo para smartphones, história em quadrinhos (HQ), games, entre outros, estabelecendo parcerias com os cursos de Computação e de Comunicação Social disponíveis no Centro universitário municipal.

O aplicativo para smartphones possibilitaria a localização de pontos de coleta de resíduos especiais como lâmpadas, pilhas e eletrônicos, óleo de cozinha, medicamentos em desuso entre outros, materiais estes que não devem ser descartados no lixo que vai para os aterros sanitários, ou nos piores casos, para os lixões, pois provocam graves consequências ambientais. E poderiam indicar as informações de horários de coleta dos resíduos recicláveis residenciais de acordo com a localização do usuário do aplicativo.

Outra possível ação sustentável para disseminar a cultura de separação dos recicláveis, seriam propostas de políticas públicas para que imobiliárias e construtoras, tornem-se agentes modificadores de comportamento social informando horários e pontos de coleta em seus novos contratos de locação ou venda de imóveis. 
Figura 1 - Capa do Folder "Lixo tem dia Certo"

LAMMPADAS FLUORESCENTES:

A Secretaria de Serviços e Meio Ambiente apoia e incentiva a Reciclus, uma associaçẫo sem fins lucrativos, que está desenvolvendo um grande movimento estruturado de coleta de lâmpadas fluorescentes ao final de seu uso, de modo a terem uma destinação final ambientalmente adequada. Estäo disponilizados pontos de coleta em cinco locais da cidade:

- Hidromar - Avenida Paulo Roberto Cavalheiro Coelho $n^{\circ}$ 1911, Parque Castelo;

- Hidromar - Avenida Chico Júlio n ${ }^{\circ} 3520$, Vila Chico Júlio;

- Hidromar - Avenida Dr. Ismael Alonso Y Alonso $n^{\circ} 2.901$, Bairro São José.

- Makro - Avenida Rinaldo Chioca s/n, Parque Progresso;

-Wal Mart - Avenida Dr. Antônio Barbosa Filho $n^{\circ} 181$, Jardim Francano;

MÓVEIS E ENTULHOS

(RESÍDUOS DA CONSTRUCCÃO CIVIL - RCC)

- Coleta (Codrate) - Avenida Coelho Net s/n - Bairro City Petrópolis (em frente à Escola Estadual Orlik Luz) Franca/SP - Telefone: (16) 3724-0808.

- Zani Caçambas - Rua Francisco Marques 1145 Vila Raycos Franca/SP - Telefone: (16) 3727-6667.

MEDICAMENTOS VENCIDOS/SOBRAS:

Jogar remédios vencidos ou sobras no lixo comum traz inúmeros prejuízos ao meio ambiente e d̀ saúde pública. As substâncias químicas presentes nesses medicamentos contaminam o solo e a água podendo afetar peixes e outros organismos vivos que servem como alimento às pessoas.

- Pontos de coleta: UBS e Rede de farmácias Droga Raia.

Fonte: elaborado pelos autores.

\section{Lixo tem dia certo!}

Campanha para conscientização a respeito dos dias corretos para coleta do lixo residencial reciclável

Q Qual o seu

(20) Separar o lixo é importante,

Prefeitura Municipal de Franca Centro Universitário Uni-FACEF - Franca - SP (6) mas não para por ai!

- Veja aqui os dias certos para colocar seu lixo reciclável na rua...

Figura 2 - Interior do Folder "Lixo tem dia Certo"

TIPOS DE LIXO:

o lixo deve ser separado entre úmidos e secos

colocados na rua em dias e horários diferentes.

RESÍDUOS ÚMIDOS:

Que são divididos em:

\begin{tabular}{|c|c|}
\hline Que são divididos em: \\
\hline ORGÂNICOS & REJEITOS: \\
\hline Restos de comida, & $\begin{array}{c}\text { Resíduos de banheiro, } \\
\text { Papel higiênico, }\end{array}$ \\
$\begin{array}{c}\text { Cascas de alimentos, } \\
\text { Papéis engordurados, } \\
\text { etc. }\end{array}$ & $\begin{array}{c}\text { Fraldas descartáveis } \\
\text { etc. }\end{array}$ \\
\hline
\end{tabular}

RESIDUUOS SECOS:

Papéis, papelão, latas, vidros, plásticos, embalagens de leite e sucos etc. (de preferência, limpos e secos)

\section{COLETA DE RESIDUOS ESPECIAIS:}

ÓLEO DE COZINHA:

Este resíduo é coletado nas escolas municipais de Franca e encaminhados à cooperativa de catadores - COPERFRAN, que posteriormente os vende para empresas licenciadas para reciclagem.

PNEUS:

Estes resíduos são recebidos e armazenados no eco ponto localizado no aterro sanitário do Município de Franca e recolhidos pela Reciclanip (Entidade sem fins lucrativos criada pelos fabricantes de pneus novos Bridgestone, Continental, Goodyear, Michelin e Pirelli).

PILHAS, PRODUTOS ELETRÔNICOS E SEUS COMPONENTES:

Há um ponto voluntário de coleta destes resíduos no Centro Universitário Uni-FACEF - Unidade II.

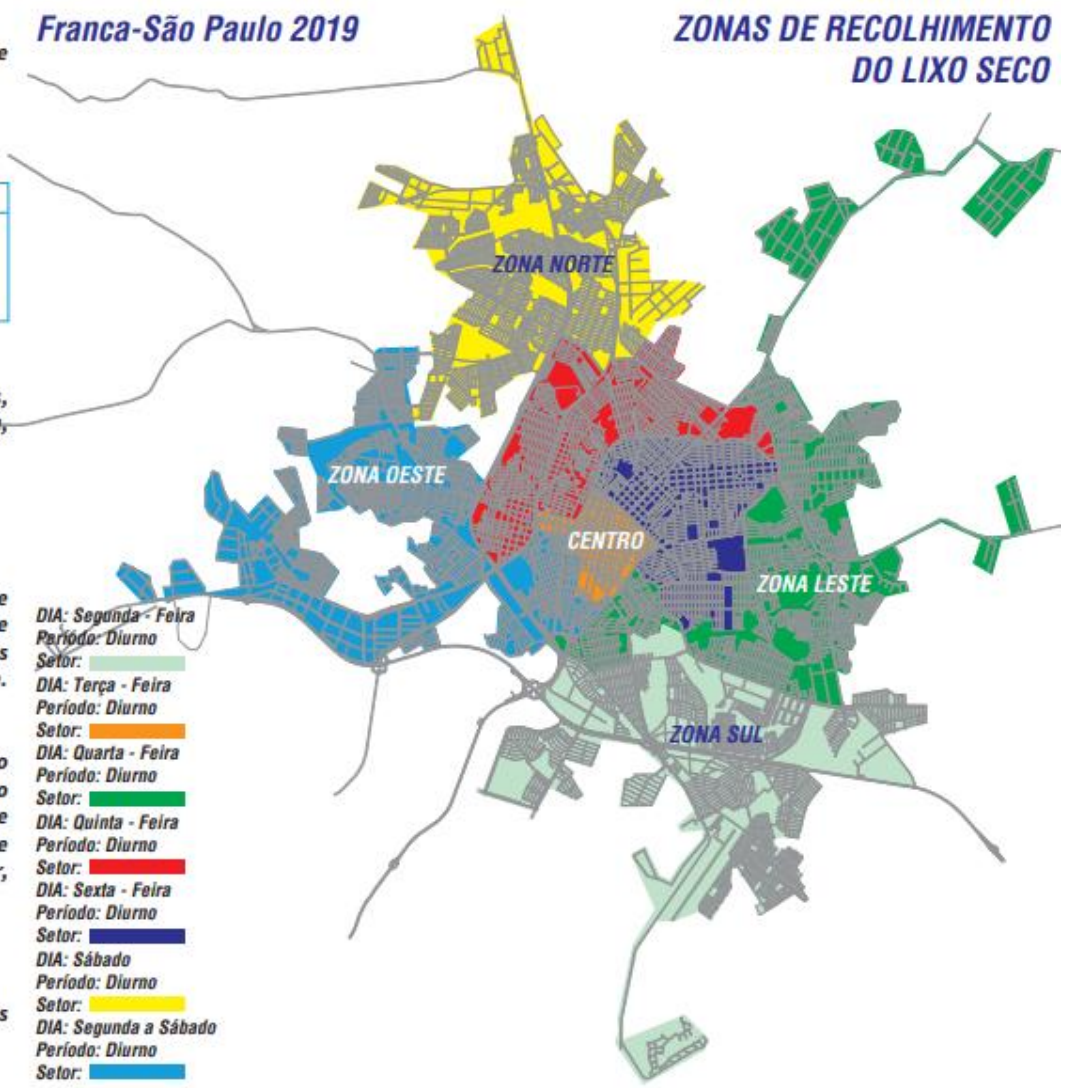


Fonte: elaborado pelos autores.

Figura 3 - Cartaz "Lixo tem dia Certo"

\section{Lixo tem dia certo!}

Qualoseu Separar o lixo é importante,
mas não para por ai!

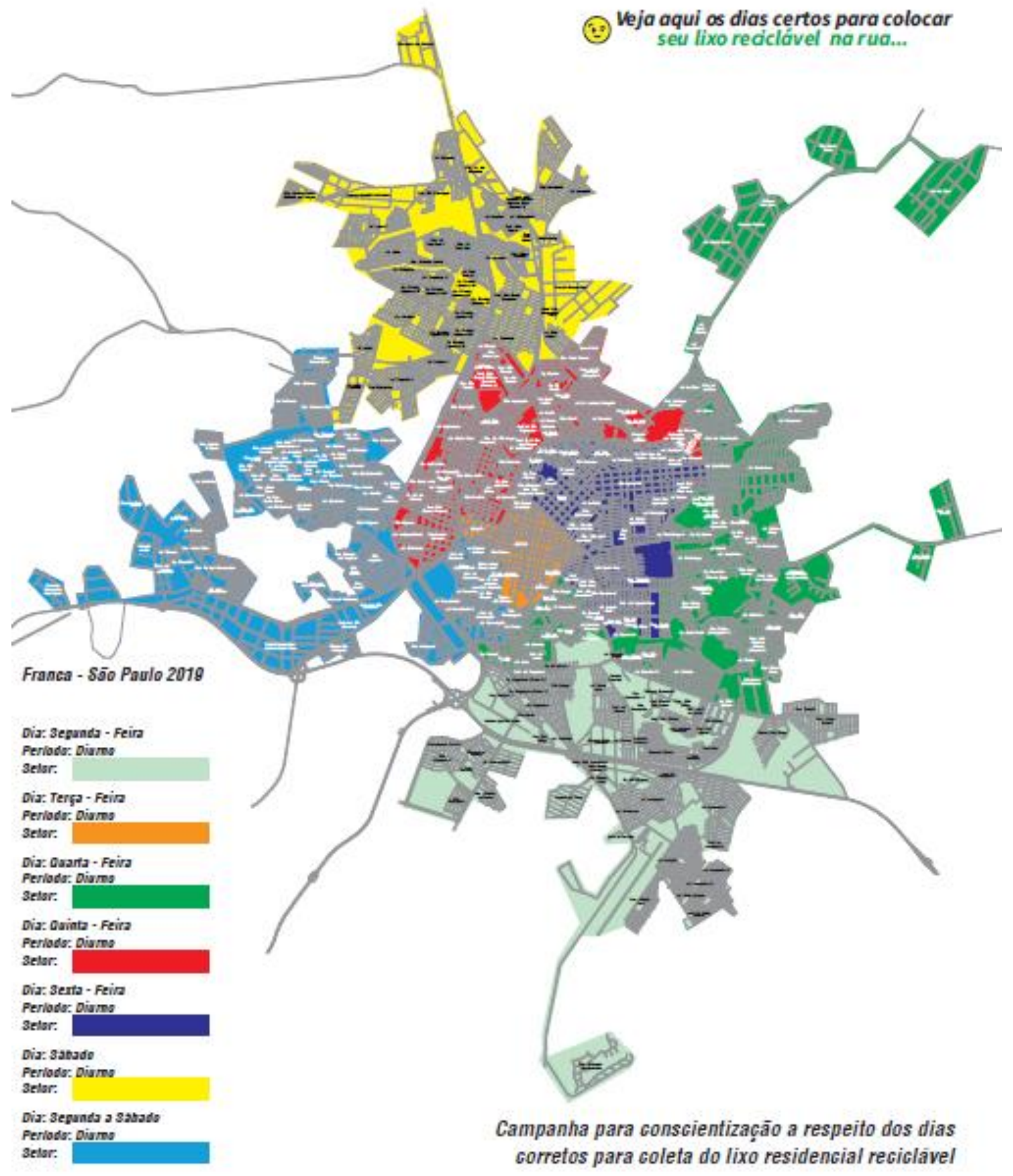

Fonte: elaborado pelos autores. 


\section{CONSIDERAÇÕES FINAIS}

A questão ambiental é urgente e este trabalho propõe ações de cooperação entre organizações, colaboração da população, materiais de promoção da educação ambiental no âmbito municipal e que demandam baixo custo, em contrapartida, faz-se necessário considerável envolvimento dos participantes.

Os conceitos de Desenvolvimento Sustentável (DS) e os problemas enfrentados na Educação Ambiental (EA) devem ser objeto de pesquisas futuras e novas propostas devem surgir com análises mais profundas acerca dos temas supracitados. Procurou-se apresentar medidas de educação para a sustentabilidade e minimização dos problemas causados pela falta de conscientização ambiental a respeito do tratamento do lixo residencial.

Foram elucidados alguns objetivos inerentes ao desenvolvimento de cidades sustentáveis descritos na "Plataforma Agenda 2030", na seção intitulada como "Cidades e Comunidades Sustentáveis", especificamente na subdivisão que aborda a "gestão de resíduos municipais".

Por fim, como modelo a ser seguido por cidades da região, por exemplo, foi apresentada uma situação problema de conscientização e uma proposta de ações práticas de educação ambiental, quanto aos procedimentos de coleta de lixo na cidade de Franca, interior do Estado de São Paulo.

\section{REFERÊNCIAS}

BARCIOTTE, Maria Lucia. Coleta seletiva e minimização de resíduos sólidos urbanos: uma abordagem integradora. 1994. 226f. Tese de Doutorado em Saúde Pública - USP: São Paulo,1994.

FURTADO, Jorge (produção). Ilha das flores - filme curta metragem. Publicado em 7 de maio, 2009. Porto Alegre, RS. Acesso em 22/07/2019. Disponível em: <https://www.youtube.com/watch?v=KAzhAXjUG28>.

IPEA / Instituto de Pesquisa Relatório de Educação Ambiental. Acesso em 23/07/2019. Disponível em: $<$ http://www.ipea.gov.br/portal/images/stories/PDFs/relatoriopesquisa/121002_relator io_educacao_ambiental.pdf>.

LIMA, Gustavo da Costa. O discurso da sustentabilidade e suas implicações para a educação. Ambient. soc., Campinas, v. 6, n. 2, p. 99-119, Dec. 2003. Available from: $<$ http://www.scielo.br/scielo.php?script=sci_arttext\&pid=S1414$753 \times 2003000300007 \&$ Ing=en\&nrm=iso>. Access on: $\overline{19}$ July 2019. 
http://dx.doi.org/10.1590/S1414-753X2003000300007.

LIMA, Luciana Leite; D’ASCENZI, Luciano. Políticas públicas de desenvolvimento econômico local nos municípios brasileiros. Congreso Latino-Americano de Ciência Política. Actas. Montevideo: ALACIP, 2017. Acesso em 28/07/2019. Disponível em: $<$ https://lume.ufrgs.br/handle/10183/168771>.

MMA. Ministério do Meio Ambiente. Coleta Seletiva, 2019. Acesso em 20/07/2019. Disponível em: https://www.mma.gov.br/cidades-sustentaveis/ residuossolidos/catadores-de-materiais-reciclaveis/reciclagem-e-reaproveitamento.html

MMA/ Saco é um Saco. Campanha de Conscientização para redução do uso de sacolas plásticas. Acesso em 23/07/2019. Disponível em: $<$ http://www.mma.gov.br/responsabilidade-socioambiental/producao-e-consumosustentavel/saco-e-um-saco.html>.

MMA/MEC. Declaração de Brasília para a Educação Ambiental. I Conferência Nacional de Educação Ambiental. Ministério do Meio Ambiente, dos Recursos Hídricos e da Amazônia Legal. Ministério da Educação e do Desporto. Brasília-DF, 1997. Acesso em 18/07/2019. Disponível em: http://www.mma.gov.br/ informma/item/

MORAN, Joe. Earthrise: the story behind our planet's most famous photo. The Guardian: 22th Dec. 2018. Acesso em 22/07/2019. Disponível em: $<$ https://www.theguardian.com/artanddesign/2018/dec/22/behold-blue-plantphotograph-earthrise>.

MURDOCH, Iris; NURIDSANY, Claude. PERENNOU, Marie. Opening Sequence: People from a planet without flowers would think we must be mad with joy whole time to have such things about us. Natural history, ISSN 0028-0712, Vol. 108, №. 4 (MAY), 1999, págs. 73-75

ONU. Conheça os novos 17 Objetivos de Desenvolvimento Sustentável da ONU. 2015a. Acesso em 19/07/2019. Disponível em https://nacoesunidas.org/ conhecaos-novos-17- objetivos-de-desenvolvimento-sustentavel-da-onu/

ONU. Transformando Nosso Mundo: A Agenda 2030 para o Desenvolvimento Sustentável. 2015b. Acesso em 19/07/2019. Disponível em https://nacoesunidas. org/ pos2015/agenda2030/

PNAD Contínua 2018 / Pesquisa Anual por Amostra de Domicílios Contínua. IBGE Instituto Brasileiro de Geografia e Estatística. Acesso em 23/07/2019. Disponível em: $<$ https://agenciadenoticias.ibge.gov.br/agencia-sala-de-imprensa/2013-agencia-denoticias/releases/24857-pnad-continua-2018-educacao-avanca-no-pais-masdesigualdades-raciais-e-por-regiao-persistem>.

PUPO, N. I.; DOMÍNGUEZ, M.I.; SOSA, D; RAMÍREZ, M.; PALMA, M. I. Investigación en la Universidad de Holguín: compromiso con la Agenda 2030 para el desarrollo sostenible. Actualidades Investigativas en Educación Abr 2019, Volume 
19 № 1 Páginas 348 - 378 https://www.scielo.sa.cr/pdf/ aie/v19n1/1409-4703-aie-1901-348.pdf

RODRIGO-CANO, D.; PICÓ, M. J.; DIMURO, G.. Los Objetivos de Desarrollo Sostenible como marco para la acción y la intervención social y ambiental. RETOS. Revista de Ciencias de la Administración y Economía Set 2019, Volume 9 № 17 Páginas 25 - 36 http://scielo.senescyt. gob.ec/pdf/retos/v9n17/1390-6291-Retos-917-00025.pdf

SACHS, Ignacy. Em busca de novas estratégias de desenvolvimento. Estud. av., São Paulo, v. 9, n. 25, p. 29-63, Dec. 1995. Available from: <http://www.scielo.br/scielo.php?script=sci_arttext\&pid=S0103-4014199500030 $0004 \&$ Ing=en\&nrm=iso>. Access on 28 July $2019<\mathrm{http}: / / d x . d o i . o r g / 10.1590 /$ S010340141995000300004>.

SANTOS, Daniela. Reciclagem de lixo na região de Ribeirão Preto não chega a 3\%. Folha de São Paulo. Ribeirão Preto: 04 de abril de 2013. Acesso em 04/08/2019. Disponível em: <https://www1.folha.uol.com.br/cotidiano/ribeiraopreto/1256878reciclagem-de-lixo-na-regiao-de-ribeirao-preto-nao-chega-a-3.shtml>.

Sociedade e economia: estratégias de crescimento e desenvolvimento / organizadores: João Sicsú, Armando Castelar. - Brasília: Ipea, 2009.

THIBES, Victoria. Tecnologias que você usa e foram descobertas pela Exploração Espacial. Canaltech: 15, junho de 2014. Acesso em 22/07/2019. Disponível em: $<$ https://canaltech.com.br/ciencia/Tecnologias-que-voce-usa-e-foram-descobertaspela-Exploracao-Espacial/>.

WCD / World Cleanup Day. Acesso em 23/07/2019. Disponível em: $<$ https://www.worldcleanupday.org/about/>

WWF/ The Morges Manifesto. We must save the World's Wild Life - An International Declaration. Belgravia, London: 29th April, 1961. Acesso em 22/07/2019. Disponível em: <http://wwf.panda.org/knowledge_hub/history/>. 


\title{
ENSINANDO PARA A SUSTENTABILIDADE ATRAVÉS DE HORTAS ESCOLARES
}

\author{
CAMPAGNOLI, Eduardo Silva \\ Licenciatura em Biologia - E.E. Prof. Antônio Pedroso \\ edudabiologia@yahoo.com.br \\ CAMARGO, Regina Aparecida Leite de \\ Doutora em Planejamento e Desenvolvimento - FCAV/UNESP \\ regina.camargo@unesp.br \\ GONÇALVES, Débora \\ Graduanda em Biologia \\ deehboragoncalves@gmail.com
}

\section{INTRODUÇÃO}

A discussão internacional sobre os problemas ambientais causados pelo modelo de desenvolvimento adotado nas chamadas sociedades modernas nasceu na década de 1960 com a formação do Clube de Roma e foi aprofundada na Primeira Conferência Mundial sobre o Meio Ambiente Humano realizada pela ONU em 1972 em Estocolmo. Em 1992 foi realizada a Conferência das Nações Unidas sobre o Meio Ambiente e o Desenvolvimento, também conhecida como Eco-92, no Rio de Janeiro, de onde saiu a primeira agenda de objetivos e diretrizes para a promoção do desenvolvimento sustentável global.

Medina (1997) aponta como algumas das principais características das sociedades contemporâneas um consumismo que anda atrelado com o isolamento, passividade política, falta de comunicação e uma velocidade crescente de informações que leva a saturação e ao tratamento da informação como fato instantâneo e não como processo. Passados vinte anos da publicação desse seu trabalho, as transformações econômicas, sociais, culturais, éticas e científico tecnológicas identificadas pela autora apresentam um ritmo cada vez mais acelerado, mas não impedem o agravamento das questões ambientais.

A necessidade de educar a população para que esta entenda, se preocupe e possa atuar junto aos problemas relacionados com o meio ambiente aparece na Agenda 21 como preceito básico para a construção de sociedades sustentáveis e é reforçada nos dezessete novos Objetivos para o Desenvolvimento Sustentável (ODSs) da ONU. O item 4.7 do Objetivo 4: "Assegurar a educação inclusiva e equitativa e de qualidade, e promover oportunidades de aprendizagem ao longo da vida para todas e todos", propõe garantir, até 2030, que todos os alunos adquiram os conhecimentos e habilidades necessários para promover 0 
desenvolvimento sustentável, inclusive, entre outros, por meio da educação e estilos de vida sustentáveis, direitos humanos, igualdade de gênero, promoção de uma cultura de paz e não violência, cidadania global, valorização da diversidade cultural e da contribuição da cultura para o desenvolvimento sustentável (ONU, 2019). Esse objetivo alinha-se com o conceito de educação ambiental como "a incorporação de critérios socioambientais, ecológicos, éticos e estéticos, nos objetivos didáticos da educação", defendido por Medina e Santos (2000, p.25).

Um programa de educação ambiental deve incorporar os efeitos evidentes de um modelo de desenvolvimento urbano-industrial onde "a natureza é coisificada, desnaturalizada de sua complexidade ecológica e convertida em matéria-prima de um processo econômico; e os recursos naturais tornam-se simples objetos para a exploração do capital" (LEFT, 2003).

A "coisificação" da natureza e sua dissociação das relações humanas, num mundo onde "a sociedade é o domínio dos homens e a natureza o das coisas" (MOSCOVICI, 1975) alicerça a ideia de que a ciência é capaz de resolver as consequências do descaso ambiental, como as mudanças climáticas, através de avanços tecnológicos. A sociedade moderna transforma-se no que Giddens (1991) denomina de "sistemas peritos", onde a tecnologia é mitificada em detrimento da valorização da observação e da experiência.

Por outro lado, o próprio desenvolvimento científico e tecnológico pode acarretar riscos e perigos nunca antes presentes na sociedade e com grande potencial para influenciar a qualidade da vida humana no planeta, ou mesmo a sua existência. Vivemos no que Ulrich Beck (1998) denomina de sociedade de risco, aos quais estão sujeitas as gerações atuais e futuras, ainda que esses riscos não atinjam o conjunto da sociedade da mesma maneira.

O projeto de educação ambiental desenvolvido pela Escola Estadual Professor Antônio Pedroso em conjunto a Universidade Estadual Paulista "Júlio de Mesquita Filho" - FCAV/UNESP/Jaboticabal, tem como objetivo geral aprofundar os conhecimentos de professores e alunos sobre as questões ambientais, através de atividades práticas e teóricas e a construção conjunta de material didático. Uma das principais iniciativas nesse sentido é a manutenção de uma horta orgânica, que funciona como uma sala de aula a céu aberto e instrumento para o estreitamento da relação dos alunos com a natureza e a produção de alimentos.

A seguir serão apresentados alguns dos fundamentos teóricos do trabalho, bem como trechos de entrevistas realizadas com professores e alunos e as etapas para a implantação da horta escolar, dentro do objetivo acima descrito. 


\section{A EDUCAÇÃO AMBIENTAL NA ESCOLA}

Para Soares et al (2019, p.6) a complexidade do mundo moderno coloca a escola frente ao dilema de manter-se:

[...] apegada a velhos conceitos, orientando currículos/conteúdos e práticas para atender a uma estrutura fechada, normativa e continuamente identificada como impositiva e restritiva, centrada num modelo disciplinar hierarquizado, ou, de outro modo, repensar-se, reavaliar-se e reorientar-se por processos autoorganizativos, realmente contextualizados histórica e culturalmente, numa perspectiva interdisciplinar.

Nesta segunda opção é fundamental entender que o conhecimento é produzido a partir do próprio sujeito e da sua inserção no universo/sociedade, observado na multiplicidade de facetas que 0 constituem como humano.

As iniciativas de educação ambiental perpetradas nas escolas devem romper com o reducionismo que tenta confinar a educação ambiental à noção de preservação de espécies e recursos naturais, por importante que sejam, e "adotar a análise das relações políticas, econômicas, sociais e culturais entre humanidade e a natureza e as relações entre os seres humanos, visando a superação dos mecanismos de controle e de dominação que impedem a participação livre, democrática e consciente de todos" (REIGOTA, 2010, p.9).

São muitos os conceitos, correntes e doutrinas que cabem dentro da discussão abrangente da questão ambiental. Para o propósito da educação ambiental em ambiente escolar, a contribuição apresentada por Sauvé (1997, apud LAYRARGUES, 2002) tem sua pertinência apoiada na complementariedade das situações de aprendizado. Segundo a autora, a educação ambiental pode se dar através da:

Educação sobre o meio ambiente: trata-se aqui da aquisição de conhecimentos e habilidades relativos à interação com o ambiente, que está baseada na transmissão de fatos, conteúdos e conceitos, onde o meio ambiente se torna um objeto de aprendizado;

Educação no meio ambiente: também conhecido como educação ao ar livre, corresponde a uma estratégia pedagógica onde se procura aprender através do contato com a natureza ou com o contexto biofísico e sociocultural entorno da escola ou comunidade. O meio ambiente provê o aprendizado experimental, tornando-se um meio de aprendizado;

Educação para o meio ambiente: é onde se busca o engajamento ativo do educando que aprende a resolver e prevenir os problemas ambientais. $O$ meio ambiente se torna uma meta do aprendizado (Sauvé, 1997, apud LAYRARGUES, 2002, p. 9).

No caso das hortas escolares espera-se que os alunos vivenciem na prática, ou seja, no meio ambiente, os conceitos aprendidos na sala formal de aula e, através do contato com a natureza, adotem uma postura ativa em relação ao ambiente. Um dos alunos participantes do projeto expressou sua relação com a 
horta da seguinte maneira: "Pra mim a horta foi um lugar para espairecer das ideias que estava tendo. $\mathrm{E}$ com isso fui influenciado a querer tornar o mundo verde $\mathrm{e}$ ecológico" (Aluno, 2019).

O aprendizado ambiental, enquanto processo permanente de tomada de consciência dos problemas ambientais, deve instigar a curiosidade, o espírito crítico e a vontade de agir na transformação da realidade. Só assim é capaz de cumprir seu objetivo de construir valores sociais e acumular os conhecimentos, atitudes e habilidades necessários para a conservação do meio ambiente (SÁ, et al, 2015). Para Paulo Freire:

O exercício da curiosidade a faz mais criticamente curiosa, mais metodicamente "perseguidora" do seu objeto. Quanto mais a curiosidade espontânea se intensifica, mas, sobretudo, se "rigoriza", tanto mais epistemológica ela vai se tornando (FREIRE, P, 1996, p.87).

Donde se deriva que a curiosidade, embora essencial para o processo de aprendizado, deve ser complementada com alguma forma de embasamento metodológico para se tornar verdadeiramente epistemológica. Ou seja, deve instigar a pesquisa dos porquês, das causas e das soluções, por ser instrumento e não finalidade do aprendizado. A horta, como parte do ambiente natural ao redor da escola é um espaço em constante transformação, onde novos desafios surgem a qualquer momento.

\section{A PRODUÇÃO E CONSUMO DE ALIMENTOS NAS SOCIEDADES CONTEMPORÂNEAS}

Atualmente é cada vez maior a distância entre as esferas da produção e do consumo de alimentos. Esse distanciamento está diretamente relacionado ao fato de que cada vez mais são as grandes empresas corporativas que determinam o que e como os agricultores devem cultivar e o que o como a população deve consumir. Os atuais sistemas produtivos, com o excesso de uso de insumos químicos e o consumo exagerado de alimentos ultra processados, acarretam problemas de saúde, como o aumento de distúrbios alimentares entre crianças e adolescentes; degradação ambiental, devido à intensificação do uso de agrotóxicos e sementes geneticamente modificadas e problemas sociais e econômicos, já que muitos pequenos e médios produtores não conseguem acompanhar a concorrência de grandes grupos de produção empresarial.

Friedmann (2016) propõe como diretrizes para o estreitamento das relações entre produção e consumo de alimentos: uma maior centralidade da soberania alimentar nas políticas de desenvolvimento, envolvendo medidas como uma renovação econômica verde; políticas de saúde que incentivem o consumo de alimentos frescos; o letramento da população quanto ao cultivo e preparo dos alimentos e a superação do hiato entre cultura urbana e rural através de estruturas 
regionais que conectem produtores e consumidores. No Brasil, essa discussão está centrada no conceito e nas ações relativas à segurança alimentar.

A II Conferência Nacional de Segurança Alimentar e Nutricional (SAN) realizada em 2004 na cidade de Olinda-PE aprovou uma concepção abrangente do termo, posteriormente regulamentada no Art. 30 da Lei № 11.346, de setembro de 2006:

\footnotetext{
"Realização do direito de todos ao acesso regular e permanente a alimentos de qualidade, em quantidade suficiente, sem comprometer o acesso a outras necessidades essenciais, tendo como base práticas alimentares promotoras da saúde, que respeitem a diversidade cultural e que sejam social, econômica e ambientalmente sustentáveis" (BRASIL, 2006)
}

O conceito de SAN anda de mãos dadas com o de soberania alimentar, definida no Fórum Mundial sobre Soberania Alimentar realizado em Havana em 2001, como o direito dos povos definirem suas próprias estratégias de produção, distribuição e consumo de alimentos (MALUF, 2007). Embora o conceito de SAN adotado no Brasil englobe alguns dos elementos da discussão internacional sobre soberania alimentar, essa vai além, sobretudo no questionamento de como e por quem os alimentos são produzidos.

Dentre as ações que visam promover a aproximação entre produtores e consumidores estão aquelas relacionadas com o emprego de alimentos produzidos localmente, e de preferência por produtores familiares, na alimentação escolar (MORGAN e SONNINO, 2008). No caso brasileiro, o programa de política pública que mais contribui para a promoção de uma maior junção entre a alimentação escolar e a produção local é o Programa Nacional de Alimentação Escolar (PNAE). A Lei 11.947 de 2009, que regulamentou o PNAE, estipulou a obrigatoriedade das prefeituras gastarem pelo menos $30 \%$ dos recursos do Fundo Nacional de Desenvolvimento da Educação (FNDE) com aquisições de gêneros alimentícios da agricultura familiar (BACCARIN et al, 2012; CAMARGO et al, 2013).

A combinação entre um conceito amplo de educação ambiental com o objetivo de promoção de uma educação para a sustentabilidade, aliada à necessidade de maior aproximação entre produtores e consumidores de alimentos faz das hortas escolares um espaço de aprendizado e construção de uma relação mais harmoniosa com a natureza e com a própria alimentação. Nesse sentido é ilustrativo o depoimento de outro aluno do projeto:

A horta é algo extremamente importante que deveria ter em toda escola por que com ela eu ganhei muito mais conhecimento em relação à natureza, tudo. Eu comecei a aprender a plantar e para mim foi um grande passo. Eu estou fazendo uma horta lá em casa. Plantei melancia e já está crescendo. A horta é como uma matéria, e ajuda muito (Aluno, 2019). 


\title{
3.1. As hortas escolares
}

Para a coordenadora pedagógica da escola onde se desenvolve o projeto aqui retratado, a horta:

\begin{abstract}
É importante pelo fato dos alunos se interessarem em saber de uma alimentação saudável, e ter cuidado com a horta e com a terra em si. Isso é muito importante.

Nas crianças dessa idade a alimentação é meio complicada, então quando eles plantam e cuidam, eles se alimentam daquela hortaliça que eles plantaram. E o cuidado que eles têm com esse ambiente é fantástico. E isso transcende para a escola, para a casa, para ao redor da escola e para a comunidade (Coordenadora Pedagógica, 2019).
\end{abstract}

Uma das professoras da escola completa que: "Os alunos passam a conhecer verduras e plantas medicinais que não conheciam e saber a sua finalidade no nosso organismo, em termos de nutrientes, vitaminas e tudo mais...também a importância do alimento saudável, sem agrotóxicos”.

A presença de uma horta na escola pode cumprir finalidades que vão desde a diminuição dos gastos com a compra de alimentos para a merenda escolar à objetivos pedagógicos ou mesmo terapêuticos. O escopo da medida depende, em grande medida, do interesse e também das habilidades e conhecimentos dos professores e colaboradores. Para MORGANO (2008, p. 9):

A horta inserida no ambiente escolar torna-se um laboratório vivo que possibilita o desenvolvimento de diversas atividades pedagógicas em educação ambiental e alimentar, unindo teoria e prática de forma contextualizada, auxiliando no processo de ensino-aprendizagem e estreitando relações através da promoção do trabalho coletivo e cooperado entre os agentes sociais envolvidos.

O estímulo ao trabalho cooperativo e o despertar no aluno sentimentos de responsabilidade e propósito podem ser vistos como um dos principais ganhos de uma horta escolar. Mas só são visíveis quando os alunos se apropriam da horta e do seu entorno como espaço onde podem expressar sua criatividade e pelo qual são responsáveis diretos. Para a diretora da escola onde o trabalho aqui descrito se desenvolve:

A horta é um ganho muito grande para a escola, principalmente para os alunos, que se empenharam e continuam se empenhado na horta. Alunos com problemas de depressão acharam na horta uma saída... e eles têm todo um cuidado de molhar e colher, mesmo nas férias (Diretora, 2019)

Ou na palavra de um dos alunos: "Para mim a horta tem sido algo motivador, algo que inspira a gente a continuar a se esforçar mais. Dá uma 
responsabilidade a mais para gente. Para mim a horta é um objetivo, ela dá um objetivo para gente" (Aluno, 2019).

A horta da Escola Estadual Professor Antônio Pedroso é um espaço que vai sendo ocupado conforme o interesse dos alunos, já que seu principal objetivo é didático. A intenção é que esse espaço se aproxime o máximo possível dos quintais das casas dos alunos, servindo de inspiração para que os mesmos reproduzam as práticas aprendidas. Como se trata de uma horta agroecológica, não são usados agrotóxicos ou adubos de alta solubilidade. Por outro lado, foi plantada uma grande variedade de hortaliças, tubérculos, ervas medicinais e plantas ornamentais. É importante que os alunos percebam que além do ganho na saúde, existe também um ganho econômico no cultivo do próprio alimento. Para uma das alunas do projeto:

Eu acho que nós produzindo nosso próprio alimento, além de melhorar a saúde traz mais benefícios, por que além de você consumir seu próprio alimento, sua própria saúde, você não prejudica tanto o meio ambiente e é uma economia também, um benefício financeiro. Com a horta na escola, além de ajudar as pessoas a cuidar do meio ambiente, você cultiva também um sentimento de cuidado e carinho à natureza (Aluna, 2019).

\section{ETAPAS DE IMPLANTAÇÃO DA HORTA}

O trabalho aqui descrito é resultado de uma parceria, desde 2017, entre a Faculdade de Ciências Agrárias e Veterinária - FCAV/UNESP/Jaboticabal e a Escola Estadual Professor Antônio Pedroso, no mesmo município, através de um projeto do Núcleo de Ensino da Pró-Reitoria de Graduação da UNESP. A horta propriamente dita teve início no primeiro semestre de 2018, como parte de uma disciplina eletiva denominada "Agricultura e Meio Ambiente".

No semestre anterior o projeto abordou tópicos de educação ambiental, com introdução a algumas práticas agrícolas, sobretudos aquelas voltadas para o manejo sustentável de ecossistemas. Nos dois casos a metodologia utilizada incluiu várias atividades práticas que estimularam os alunos a buscar respostas para as questões colocadas nos resultados de experimentos ou em fontes segundarias, como a internet. Coube às duas alunas bolsistas do projeto preparar, com supervisão da coordenadora e professores colaboradores, o material didático das oficinas. Para tanto, foi primeiro realizado um levantamento do que já existia, sobre os temas abordados, no Currículo do Estado de São Paulo e nos materiais didáticos utilizados pelos professores.

Durante o projeto foram trabalhados os seguintes temas com professores e alunos:

- A produção de alimentos, biocombustíveis e matéria prima na chamada agricultura moderna e seus efeitos ambientais.

- Ecossistemas e biomas - com visitas ao horto florestal e demais coleções de plantas da Unesp. 
- Agricultura e sustentabilidade: práticas agrícolas que estimulam a sustentabilidade como plantio direto, agricultura de precisão, integração lavourapecuária. Visita à Embrapa Pecuária Sudeste de São Carlos

- Formas sustentáveis de produção: a agricultura orgânica, a agroecologia, os sistemas agroflorestais.

- Produção caseira de hortaliças e ervas medicinais: horta caseira, hidroponia, diferentes métodos de irrigação.

- A água no mundo atual: disputas, políticas e medidas de conservação e manejo. Curso intensivo para alunos e professores com quatro dias de duração.

O projeto vem sendo desenvolvido com a participação direta de quatro professores colaboradores da Escola Estadual Professor Antônio José Pedroso, duas alunas de graduação bolsistas do Núcleo de Ensino e três alunos de graduação bolsistas de outros projetos. Em torno de noventa alunos da escola pública participaram do projeto ao longo do ano de 2018 e em 2019 cerca de 150 alunos participam de alguma atividade na horta ou jardim da escola. Dentre os resultados positivos do projeto, além dos já citados ao longo do trabalho, podemos elencar: a aproximação entre a Universidade e a escola pública de ensino fundamental e médio; o envolvimento dos alunos e professores; uma percepção mais ampla da educação ambiental; o aprendizado de práticas de horticultura caseira; o melhor desempenho dos alunos em outras disciplinas, como matemática e ciências e o despertar do interesse dos alunos por uma alimentação mais saudável

\section{CONSIDERAÇÕES FINAIS}

O trabalho com alunos do ensino médio e fundamental em hortas escolares apresenta uma série de desafios, mas também resultados que podem ser muito gratificantes. Alguns pontos que necessitam ser levados em consideração são: a adequação do espaço disponível na escola com as necessidades de uma horta; a disponibilidade de alunos e professores cuidarem da horta em finas de semana, feriados e períodos de férias; a percepção da horta como um espaço de expressão da criatividade, da curiosidade e do aprendizado - é necessário que os alunos se apropriem do espaço, mas ao mesmo tempo aprendam os princípios básicos do cultivo de plantas.

Para que a atividade atinja seus objetivos, é também necessário que um ou mais dos envolvidos tenha prática no cultivo orgânico de hortaliças, ou que o projeto conte com um assessor nesse sentido. Uma horta mal cuidada, que não produz o desejado, pode desestimular alunos e professores.

Por fim, o projeto deve ter um forte viés interdisciplinar, e tecer as pontes entre o cultivo de uma horta e um jardim e todas as dimensões da sustentabilidade e da educação ambiental. 


\section{REFERÊNCIAS}

BECK, U. Risk Society. Towards a New Modernity. London: Sage Publications, 1998.

FREIRE, P. Pedagogia da Autonomia. São Paulo: Paz e Terra, 1996

GIDDENS, A. As Consequências da Modernidade. São Paulo: Ed UNESP, 1991

GOHN, M. da G. Educação não formal, aprendizagem e saberes em processos participativos. Investigar em Educacão. IIa série, número 1. p. 35-50. 2014.

LAYRARGUES, P. P. EDUCAÇÃO NO PROCESSO DA GESTÃO AMBIENTAL: criando vontades políticas, promovendo a mudança. In: ZAKRZEVSKI, S.B.B., VALDUGA, A.T., DEVILLA, I.A. (Orgs.) Anais do I Simpósio Sul Brasileiro de Educação Ambiental. Erechim: EdiFAPES. p. 127-144. 2002.

LEFT. E. A Geopolítica da Biodiversidade e o Desenvolvimento Sustentável: Economização do Mundo, Racionalidade Ambiental e Reapropriação da Natureza. Em MARTINS, R.C.; VALENCIO, N.F.L.S. Uso e Gestão dos Recursos Hídricos no Brasil, São Carlos/SP: RIMA, 2003

maturanA, H; VARElA, G. A Árvore do Conhecimento. Campinas: Editorial Psy II, 1995.

MEDINA, N. M. Educação Ambiental para o Século XXI \& A Construção do Conhecimento: suas implicações na Educação Ambiental. Brasília: Instituto Brasileiro do Meio Ambiente e dos Recursos Naturais Renováveis, 1997. 38p. (Série Meio Ambiente em Debate, 12)

MEDINA, N. M.; SANTOS, E.C. Educação Ambiental: uma metodologia participativa de formação. Petrópolis, RJ: Vozes, 2000.

MORGADO, F. S; SANTOS, M. A. A. A horta escolar na educação ambiental e alimentar: experiência do projeto horta viva nas escolas municipais de Florianópolis. EXTENSIO - Revista Eletrônica de Extensão. Número 6, ano 2008

ONU. 17 Objetivos para transformar nosso mundo. In: https://nacoesunidas.org/pos2015/. Acesso em 02/01/2019

MOSCOVICI, S. Sociedade contra a Natureza, Petrópolis, RJ: Vozes, 1975

MORIN, E. Introdução ao pensamento complexo. Lisboa:Instituto Piaget, 2001.

REIGOTA, M. O que é Educação Ambiental. São Paulo: Editora Brasiliense, 2010. 
SÁ, M. A; MARCONDES, A.O; NOVAES, A.S.R. A importância da educação ambiental para o ensino médio. Revista Brasileira de Educação Ambiental. São Paulo, V. 10, № 3: 60-68, 2015.

SAUVÉ, L. Educação Ambiental: possibilidades e limitações. Educação e Pesquisa, volume 31, n. 2. maio/agos. 2005. p. 317 - 322.

SOARES, A.M.D; OLIVEIRA, L.M.T; PORTILHO, E.S; CORDEIRO, L.C; CAVALCANTE, D.K. Educação ambiental: construindo metodologias e práticas participativas.

In www.anppas.org.br/encontro anual/encontro2/GT/GT10/ana maria dantas.pd. Acesso em 02/01/2019. 

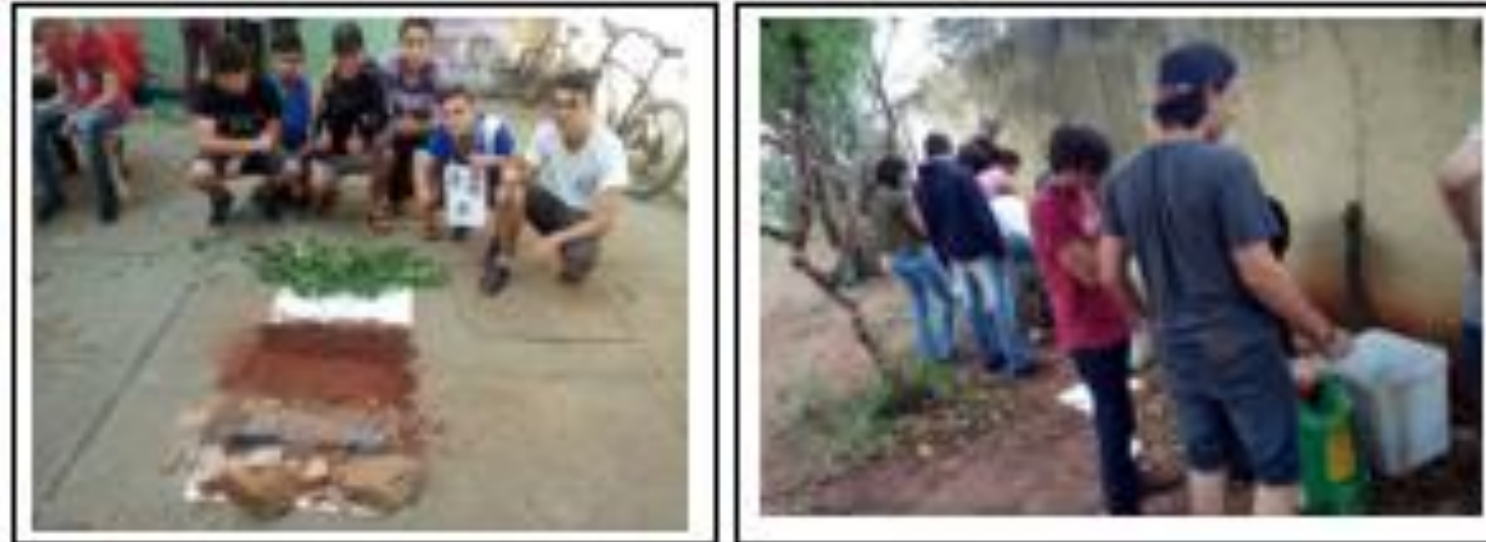

Figura 1: Alunes montando um perfil de sols

Figura 2: Alunes aprendendo a fazer composto
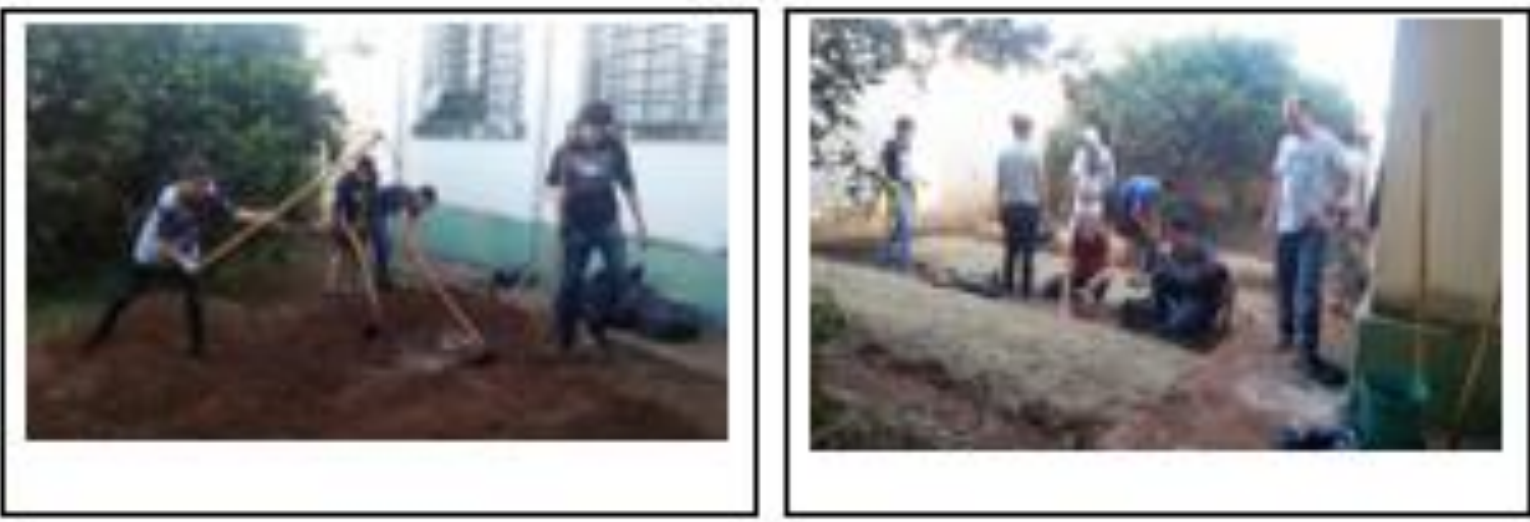

Figura 3: Aluncs preporando os canteiros da horta

Figura 4: Alunos probegendo os canteirca com cobertara morta
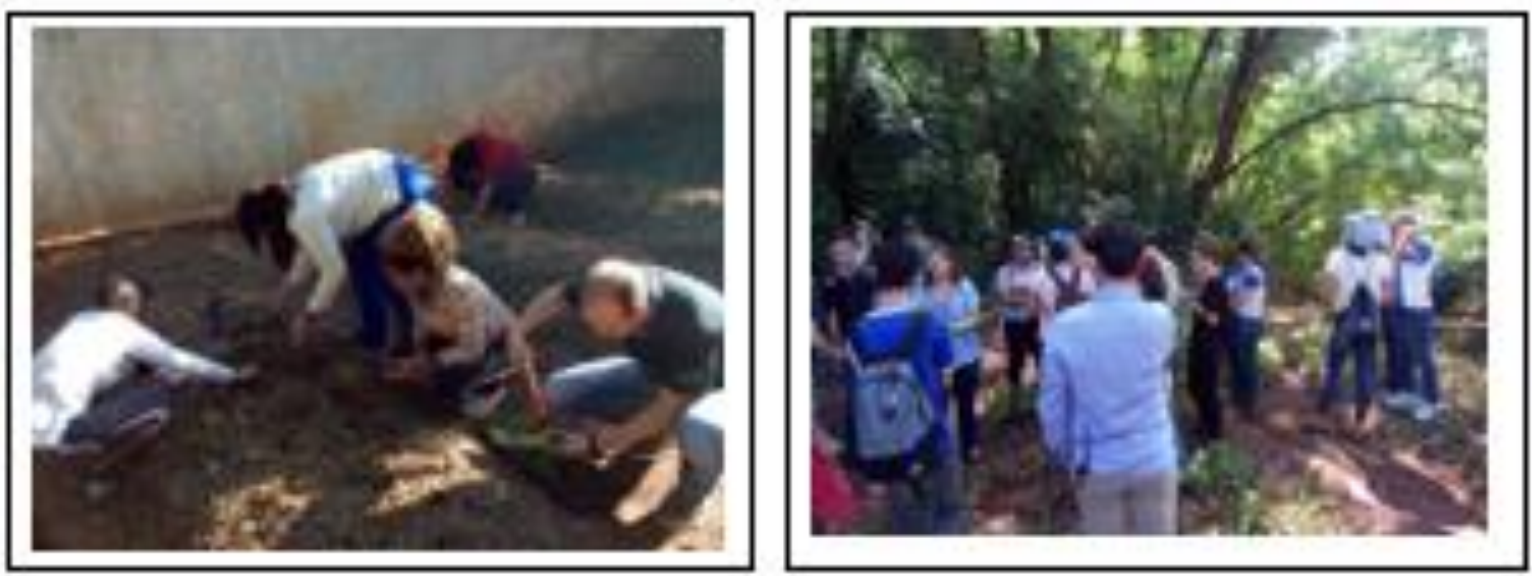

Flgura 5: Alunes e protessor trabalhando na hata

Figura E: Alunos vistando a bacia hidrografica do Corrego RicoiJaboticabal 


\title{
POLÍTICA PÚBLICA EXITOSA DE EDUCAÇÃO AMBIENTAL: Programa Educacional de Difusão do Pau-Brasil em Franca-SP
}

\author{
BERTELLI, Célio \\ Docente - Uni-FACEF \\ LOPES, Matheus Fernandes A. \\ Licenciatura - UNESP/Franca \\ BRITO, Erilze Maria da Silva \\ Mestra - UFPE
}

\section{INTRODUÇÃO}

A Estação Ecológica do Tapacurá (EET) foi criada em 18 de maio de 1975, através da Resolução no 51/75 do Conselho Universitário da Universidade Federal Rural de Pernambuco. Suas atribuições estavam todas alocadas no campo da ecologia operacional e surgiram, principalmente, em face do ano de 1970 ter sido marcado como o período em que o Pau-Brasil (Paubrasilia echinata) esteve em condição de possível extinção. A Estação está situada no Município de São Lourenço da Mata, em Pernambuco, e possui área total de 428 hectares. Instalada em abril do mesmo ano por meio da iniciativa do Professor João Vasconcelos Sobrinho - engenheiro agrônomo e ecólogo pioneiro no campo dos estudos ambientais no Brasil —, rapidamente iniciou a produção de mudas nativas da Mata Atlântica, atingindo uma média de 80.000 mudas/ano. Dentre as mudas de maior produção, é possível citar: Pau-Brasil; Ipê-Roxo e Pau-de-jangada.

O professor Paulo Martins, zootecnista, foi coordenador da estação entre 1990 e 2017. Foi durante esse período, mais especificamente em 1995, que uma parceria com a Prefeitura Municipal de Franca, localizada no Estado de São Paulo, foi realizada. A parceria aconteceu através da Secretaria de Meio Ambiente e do engenheiro agrônomo Célio Bertelli, onde foram doados $0,5 \mathrm{~kg}$ de sementes de Pau-Brasil com o intuito de criar em Franca um Banco de Germoplasma de PauBrasil, o que permitiu a criação também de um programa educacional de difusão dos valores econômicos, culturais e sociais da árvore símbolo nacional2. Quem viabilizou esse contato, foi a ilustradora botânica Erilze Maria da Silva Brito, garantindo que houvesse uma relação direta entre um Município do interior do Estado de São Paulo e outro do interior do Estado de Pernambuco.

\footnotetext{
${ }^{2}$ O Pau-Brasil foi a espécie considerada como a Árvore do Símbolo Nacional em 1978, através da Lei Federal n. ${ }^{\circ}$ 6.607, instituindo o dia 3 de maior como 'O Dia Nacional do Pau-Brasil
} 
O projeto se mantém vivo desde então, atestando uma política de educação ambiental por mais de 23 anos consecutivos. Isto é, garantindo não só a difusão da relevância histórica, econômica e cultural do Pau-Brasil, como também estimulando a promoção ambiental e a possibilidade de se pensar o desenvolvimento de Franca levando em conta sua condição ecológica. Durante o período de vigência, foram realizadas atividades em 71 unidades escolares do Município de Franca - sendo elas municipais, estaduais e particulares -, universidades e em outros Municípios, como é o caso da Praça Pau-Brasil em Patrocínio Paulista. Por fim, é preciso salientar que este projeto alçou condição de reconhecimento internacional no ano de 2005, onde foi auferido pela Câmara de Comércio e Indústria Brasil-Alemanha o prêmio Von Martius de Sustentabilidade. Também foi premiado pelo Toll Excellence Awards da Internacional Bridge Tunnel and Turnpike Association (IBTTA) - que representa internacionalmente a indústria dos pedágios - em 2006 e pelo 4ํㅡㄹ Benchmarketing Ambiental Brasileiro no mesmo ano, do Mais Projetos Corporativos.

\section{METODOLOGIA}

A metodologia adotada se orienta na construção de uma pesquisa qualitativa, por meio de levantamento bibliográfico e análise exploratória dos documentos e referências. Segundo Gil (2002), tal opção estimula a abertura de outros projetos que possam incentivar e aprofundar as discussões acerca da ecologia, da relevância do Pau-Brasil e de suas potencialidades pedagógicas. Deste modo, também permite ecoar a experiência exitosa de educação ambiental como alternativa para a formação, proteção e conservação da flora brasileira no curto, médio e longo prazo em consonância da sustentabilidade com a biodiversidade. 


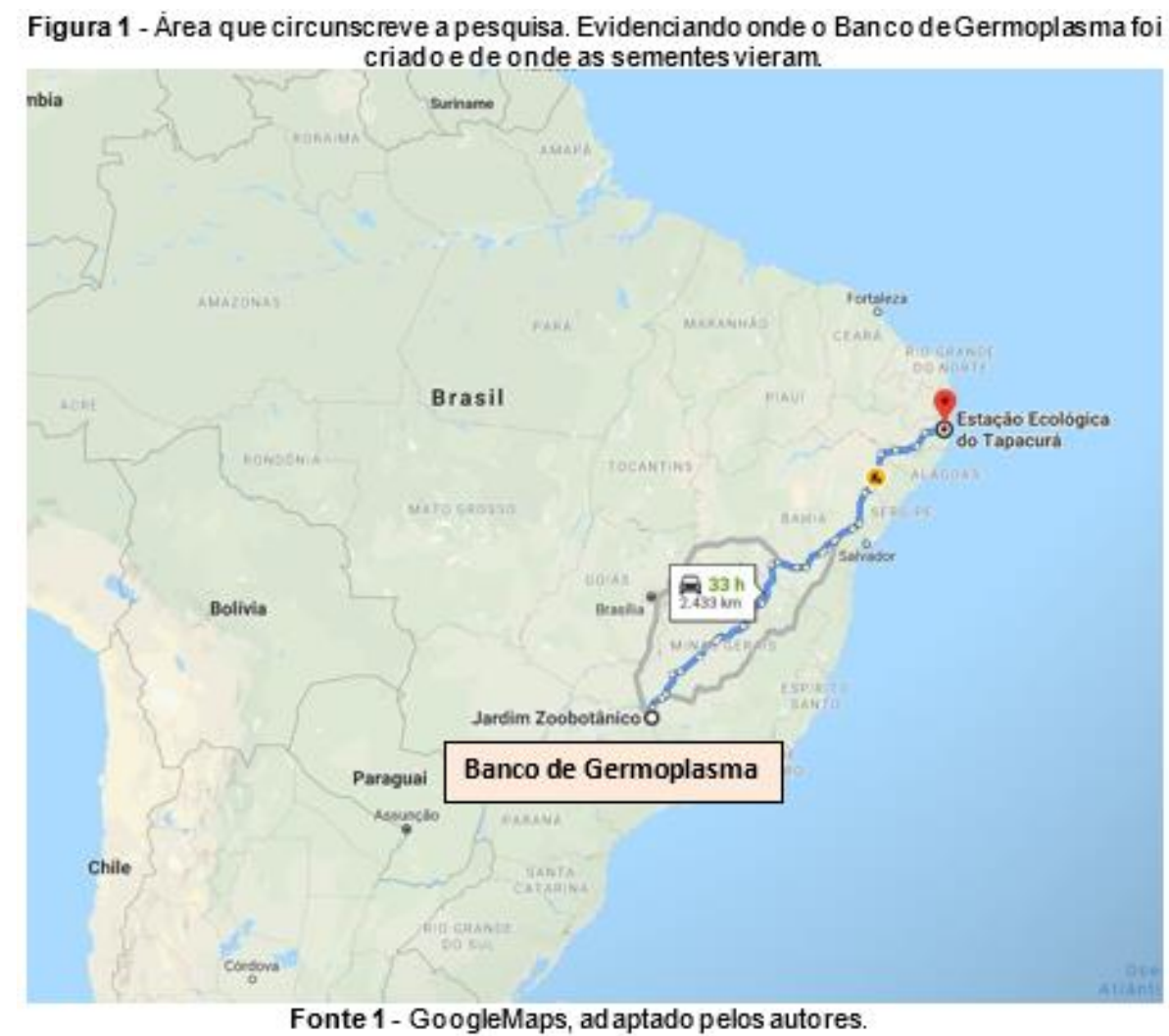

\section{OBJETIVO}

O objetivo do presente artigo é evidenciar a experiência exitosa do programa de difusão educacional do Pau-Brasil no Município de Franca, no contexto pedagógico do ensino e aprendizado local, na proteção e conservação de uma espécie ameaçada. Além disso, também visa aprofundar a reflexão no que tange às alternativas no campo da sustentabilidade.

\section{REFERENCIAL TEÓRICO}

O Município de Franca localiza-se na porção nordeste do Estado de São Paulo, tendo como área total $609 \mathrm{~km}^{2}$. Onde, segundo o IBGE (2010), possui 84 $\mathrm{km}^{2}$ de área urbana e população de 318.640 habitantes. O planalto francano encontra-se em área bastante elevada - 1040 metros de altitude - e tem predomínio do bioma cerrado na maior parcela da área do Município. Restando às encostas, apenas, a presença de Mata Atlântica.

Foi através de uma parceria entre a Prefeitura Municipal de Franca, por meio do Jardim Zoobotânico, e a Estação Ecológica do Tapacurá (EET), mantida pela Universidade Federal Rural de Pernambuco, que deram início às atividades do 
programa educacional de difusão Pau-Brasil. O programa consistia, basicamente, no intercâmbio de sementes produzidas na EET com o Jardim Zoobotânico de Franca, que por sua vez, estimulou a partir destas sementes a criação de um Banco de Germoplasma de Pau-Brasil para a produção de mudas da espécie.

Foi cedido, em 1995, pelo professor Paulo Martins, aproximadamente $0,5 \mathrm{~kg}$ de sementes do Pau-Brasil ao professor Célio Bertelli. O objetivo principal era o plantio e o cultivo da espécie, o que permitia estimular um grande circuito de promoção ambiental a partir de atividades educacionais nas unidades escolares de Franca. E, além das escolas de Franca, a equipe do Jardim Zoobotânico também estabeleceu relações e atividades nas instituições de ensino superior do Município, bem como com outros Municípios como é o caso de Patrocínio Paulista. Ou seja, tanto a UNESP, a Uni-FACEF como a UNIFRAN, participaram das ações educativas e, sobretudo, do plantio de mudas, denominado como "Ecotrote".

O Jardim Zoobotânico, por sua vez, foi criado em 17 de julho de 1998 através da Lei $n .05 .048$. Sua criação representou um passo à frente na defesa e no estímulo às melhores tratativas do meio ambiente, afinal, a criação de tal instituição significava a instauração da primeira Unidade de Conservação Municipal de envergadura e projeção. Para viabilizar toda essa estrutura, o Jardim Zoobotânico conta com área aproximada de 200 hectares, onde detém coleções de plantas "in situ" e "ex situ", mudas para a arborização urbana, circuitos de educação ambiental programados e, principalmente, a produção de mudas para o reflorestamento de áreas de preservação permanente (APP) e para o paisagismo urbano.

Destacam-se os seguintes resultados:

- Em Franca, o Jardim Zoobotânico Municipal, onde há um bosque de pau-brasil com mais de 300 árvores plantadas 2001, é o jardim botânico paulista que tem a maior coleção de árvores de pau-brasil em todo o país (ROCHA, 2004).

O Pau-Brasil (Paubrasilia echinata) ocorria na faixa litorânea, estando presente no perímetro que parte do Rio Grande do Norte até o Rio de Janeiro, isto é, cobrindo quase toda a faixa da costeira brasileira. Presente na Mata Atlântica, o Pau-Brasil sofreu intensa exploração no século XVI, tendo sido um dos exemplares na mais importantes na consolidação desta primeira fase extrativista (PRADO JúNIOR, 2012), como diria Caio Prado Jr., da colonização.

Por volta de 1550, o Brasil é ainda para o português e o europeu o país dos troncos vermelhos ou violáceos que talhados em móveis preciosos, começam a adornar as residências de Lisboa ainda no século XVI (ANDRADE, 1975, p. 32).

Antes do descobrimento do Brasil e do Pau-Brasil, o corante vermelho presente no mercado europeu - uma vez que o vermelho é tido como a cor símbolo de dignidade e de nobreza - era obtido através das "conchas de púrpura encontradas na costa do Mediterrâneo, com o 'verzino' do Oriente, com a 'urzela' 
das ilhas africanas [...] e com outras espécies de Pau-Brasil nativo da Colômbia, das Antilhas e Guianas (brasileto) e Japão (sapã ou pau-do-japão)" (SOUZA, 1984).

É possível compreender a relevância do Pau-Brasil em uma análise da série histórica, isto é, como uma espécie que desde os primórdios da colonização até os dias de hoje manteve sua importância. Não à toa, através da Lei Federal no. 6.607 de 1978, o Pau-Brasil transformou-se em Árvore Símbolo Nacional e garantindo o dia 3 de maio como o "Dia Nacional do Pau-Brasil".

Mas, devido à devastação intensa das matas do litoral brasileiro em busca do Pau-Brasil, diversas leis foram criadas com o intuito de garantir sua longevidade e impedir sua extinção. A primeira delas nos remete à 1542, onde consta na Carta Régia disposições que determinam normas disciplinatórias para o corte, assim como também instauram punição para ao desperdício de madeira. Outras cartas versaram sobre tal ainda durante o período da Colônia: Carta de Regimento (1594) e o Regimento do Pau-Brasil (1605). Séguin e Carrera (SÉGUIN; CARRERA, 1999) vão além: indicam que o Regimento do Pau-Brasil é a primeira manifestação legal e universal que versa sobre a proteção da cobertura florestal em solo brasileiro.

Os anos se passaram e assim como as cartas e os regimentos durante a Colônia, tanto no Império quanto na República, o Pau-Brasil continuou a ser tratado com reverência. Um ótimo exemplo é justamente o Código Florestal Brasileiro de 1965(BRASIL, 1965), em plena ditadura militar, que também cria disposições e diretrizes para tratar da ocupação e das permissões para avançada rumo ao interior e as áreas rurais do Brasil. Contudo, foi necessária sua quase extinção para que o Pau-Brasil fosse tratado e reconhecido à altura de seu feito histórico, sendo somente institucionalizada sua relevância, como já foi citado, em 1978.

De acordo com publicação recente, o Pau-Brasil recebeu um novo nome científico. Anteriormente conhecido e categorizado por Lamarck em 1789 como Caesalpinia echinata, na família Fabaceae. De acordo com o Globo (2019), em 2016, o novo gênero Paubrasilia está descrito num artigo publicado pelo periódico científico "Phytokeys", assinado por pesquisadores de diversas instituições como: Universidade Estadual de Feira de Santana na Bahia, Universidade de Montreal no Canadá e diversas outras. Portanto, na nova configuração, o nome correto do Pau-Brasil passa a ser Paubrasilia echinata.

Trata-se de uma espécie (CARVALHO, 2003) com frutos na forma de vagens recobertas por espinhos que se formam logo após a floração. Cada flor da origem a um fruto que carrega de uma a três sementes, onde em menos de cinquenta dias eles amadurecem e deixam cair as sementes. As sementes, por sua vez, quando frescas, tem alto poder germinativo assim que caem ao chão e começam a desenvolver em cinco dias. Em um quilo de sementes, há cerca de 3600 unidades, onde mais de $70 \%$ delas podem gerar novas mudas (PREFEITURA DE 
FRANCA, 2005). As folhas são responsáveis pela sombra acolhedora do Pau-Brasil e tem uma tonalidade verde brilhante que difere das outras árvores. Sua nervura central, quase sempre aculeada, se insere firmemente nos galhos e emite, alternadamente, de 3 a 10 pinas, contendo em cada uma entre 8 e 10 folíolos em formato de losango com bordas arredondadas e alternadas.

\begin{abstract}
A plasticidade é de grande importância ecológica, pois as sementes podem germinar em qualquer situação de luz em que se encontra. Esse resultado indica que as sementes de $C$. echinata podem germinar tanto a pleno sol quanto em clareira ou em sub-bosque. Fontes (1979) informou que a germinação de sementes de $C$. echinata, quando processada imediatamente após a colheita, pode atingir até 95\% (AGUIAR, 2005, p. 872).
\end{abstract}

As flores parecem orquídeas, porém com um perfume mais suave que a Dama da Noite (Cestrum nocturnum). Das suas cinco pétalas, a superior é salpicada na cor púrpura, é dali que sai o perfume que atrai os polinizadores, como é o caso da abelha italiana (Apis mellifera ligustica). Tais flores perduram por um período pouco de menos de uma semana, tendo a floração entre os meses de novembro e dezembro. Por fim, a última constatação importante para diferenciação visual do Pau-Brasil está presente no tronco, onde é possível visualizar os acúleos - equivocadamente chamados de espinhos.

O Programa Educacional de Difusão do Pau-Brasil em si, se iniciou a partir do intercâmbio de sementes da espécie entre o Jardim Zoobotânico de Franca (SP) e a Estação Ecológica do Tapacurá (PE). Logo após o recebimento das sementes, com apoio institucional do IBAMA de Ribeirão Preto, o Jardim Zoobotânico iniciou a criação de um Banco de Germoplasma do Pau-Brasil "Exsitu"3.

Logo em seguida, o Banco foi enriquecido com outros 70 novos espécimes de Pau-Brasil, doados justamente pelo apoio institucional do IBAMA, através da diretora Eliana Vieses Velocci Ramia, que por meio da FLONA (Floresta Nacional) em Lorena-SP, disponibilizou 1.000 mudas de Pau-Brasil.

Constituído o Banco de Germoplasma e, portanto, a possibilidade de reproduzir as espécies no próprio Jardim Zoobotânico de Franca para sua finalidade pedagógica e cultural, as atividades educacionais iniciaram. Onde, o objetivo principal era construir um circuito completo que envolvesse o Pau-Brasil. Partindo do fornecimento de sementes destinadas à produção de mudas, que por consequência aumentariam a variabilidade genética, além de proteger e disseminar a espécie na região e chegando até a conscientização ecológica através da vocação educacional do programa. Ou seja, trata-se de programa educacional que atendeu às principais escolas públicas e privadas de Franca, seja por meio das palestras ou por meio do

\footnotetext{
${ }^{3}$ Ex-situ se refere à uma coleção de espécies cuja origem não remete ao local onde estão inseridas. No caso do PEDPB, as sementes foram doadas pela Estação Ecológica do Tapacurá, constituindo um banco genético ex-situ se analisada a perspectiva de Franca.

POLÍTICA PÚBLICA EXITOSA DE EDUCAÇÃO AMBIENTAL: Programa Educacional de Difusão do Pau-Brasil em Franca-SP - pp. 82-93
} 
cultivo e plantio coletivo com os alunos, transformando-se em uma ótima plataforma para salientar a importância cultural, histórica e econômica da espécie no Brasil.

Além da rotina de plantio das mudas em 71 unidades escolares, também foi realizada uma atividade de dimensão ainda maior, que envolveu as quatro grandes universidades do município de Franca (UNESP, Faculdade de Direito de Franca, Uni-FACEF e UNIFRAN). A data escolhida foi chegada dos calouros às universidades, onde através de uma parceria com as instituições, foi realizado um evento denominado "Ecotrote". Nessa oportunidade foram plantadas 310 mudas, onde cada universidade recebeu aproximadamente 75 mudas (PREFEITURA DE FRANCA, 2005). Para além das intervenções que envolvem instituições educacionais, o projeto também se inseriu na comunidade em geral, permitindo que a plataforma educacional fosse também levada aos habitantes do município de Franca.

Foi por meio deste importante e longevo projeto - teve seu início em 1995 e encontra-se ativo até os dias de hoje - que o Jardim Zoobotânico de Franca foi reconhecido no Brasil e no Mundo. A prova é a certificação através dos prêmios recebidos: em 2005 o Prêmio Ambiental "Von Martius", entregue pela AHK Câmara Brasil-Alemanha; em 2006 o Prêmio 4ํㅗ Benchmarketing Ambiental Brasileiro, entregue pelo Mais Projetos Corporativos e também em 2006 o Certificado de Mérito ao Programa Educacional de Difusão do Pau-Brasil entregue pela Internacional Bridge Tunnel and Turnpike Association (IBTTA) na Toll Excellence Awards, em Washington DC (USA).

\section{RESULTADO E DISCUSSÃO}

É possível perceber que quando uma política pública é incorporada ao labor do executivo, independente da gestão que o dirija, sua possibilidade de sucesso aumenta. Foi assim com o programa em questão, afinal, são 7 gestões envolvidas, onde passaram pela administração pública quatro prefeitos distintos (Ary Balieiro, Gilmar Dominici, Sidnei Rocha, Alexandre Ferreira e Gilson de Souza), resultando em um programa de 23 anos de durabilidade

Todavia, tal condição só foi viabilizada pela construção de um projeto global, que garantia a autonomia do Município em termos de produção e plantio de mudas. Para tal, a existência do Banco de Germoplasma de Pau-Brasil foi fundamental para que o alargamento da produção e distribuição de mudas acontecesse: 
Figura 2 - Banco de Germoplasma do Pau-Brasil (Coleção "Ex-situ")

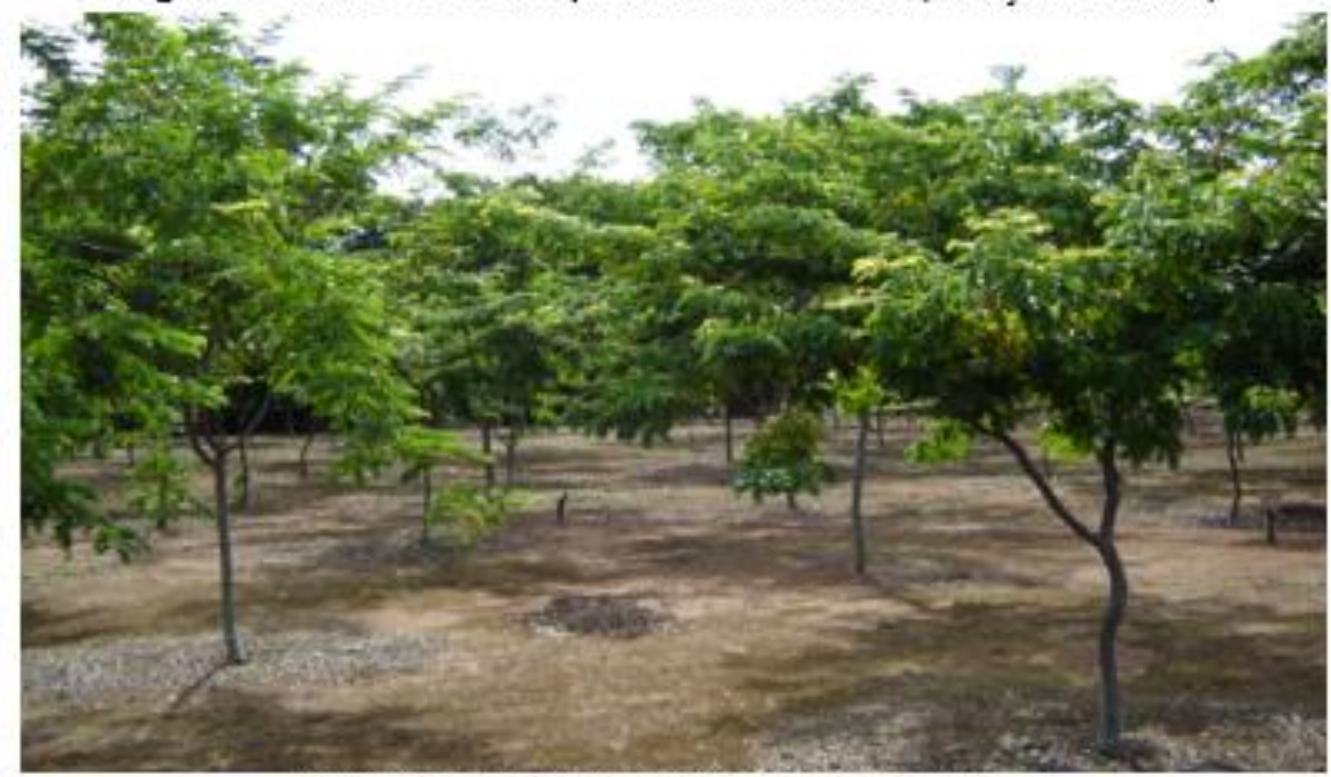

Fonte 2 - Jardim Zoobotânico de Franca. 2005

Foi somente através dessa iniciativa que os contornos do programa educacional foram viabilizados. Uma vez que é preciso garantir a continuidade da produção de mudas para que o plantio possa ser organizado e realizado no maior número de escolas possíveis.

Figura 3 - Plantio de mud as de Pau-Brasilna E. E. Torquato Saleico, no ano de 2006 .

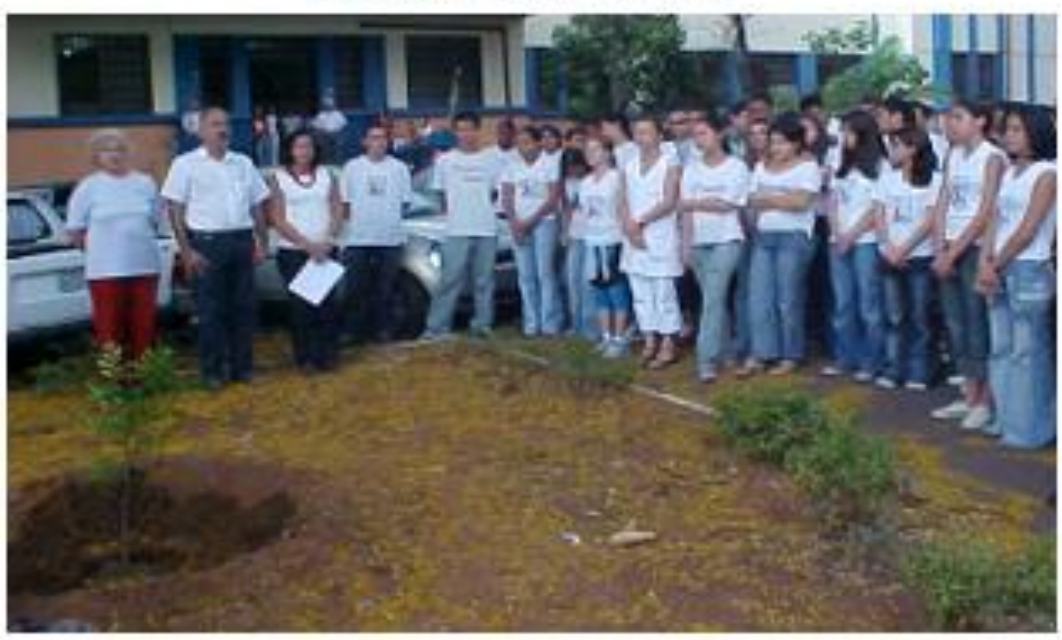

Fonte 3 - Jardim Zoobotânico, 2006.

$\mathrm{Na}$ pesquisa científica verificou-se o comportamento vegetativo e reprodutivo do Pau-Brasil sob as condições climáticas e edáficas do planalto francano - visto que se trata de uma espécie endêmica da Mata Atlântica. Através 
da dendrometria constatou-se que as plantas se desenvolveram de maneira bastante satisfatória, alcançando a idade reprodutiva precocemente.

Logo após a sua implantação, o Bosque do Pau-Brasil tornou-se uma das áreas temáticas que mais desperta interesse nos visitantes do Jardim Zoobotânico. Anualmente o local recebe inúmeros visitantes, onde a difusão das informações referentes à importância cultural, histórica e econômica são fornecidas por monitores do próprio Jardim Zoobotânico.

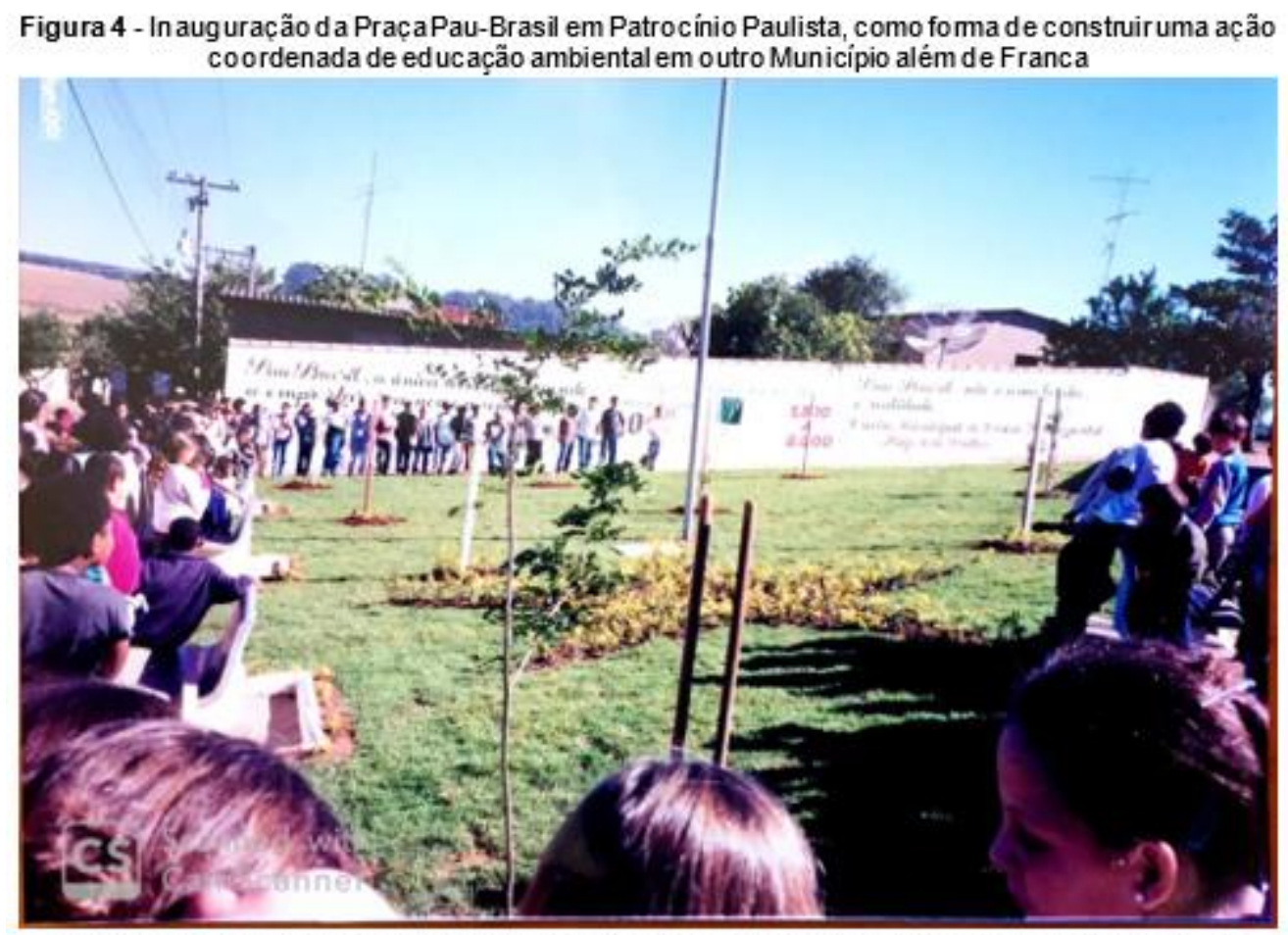

Fonte 4 - Praça Pau-Brasil em Patrocínio Paulista, no dia de 22 de abril de 2000. Disponivel em: Ecoplans Brasil Consultoria Ambiental

Para se ter noção, só no ano de 2004, foram 106 plantas que frutificaram, gerando 8.231 sementes viáveis. Onde essas 8.231 sementes deram origem a 6.770 mudas de Pau-Brasil. Todas foram empregadas no projeto, seja para plantio nas praças, nas escolas ou junto da comunidade e as universidades do município.

O projeto segue ativo até hoje, entretanto, com uma atenção especial destinada aos habitantes da cidade. Além das parcerias anteriores, foi construída uma nova parceria com o Grupo Verdejar Franca, ligado ao Mulheres do Brasil. Através do Verdejar, mudas são plantadas nas praças em conjunção com uma oficina de formação sobre a relevância do Pau-Brasil para o município e para o meio ambiente. 
Figura 5 - Plantio de mud as de Pau-Brasil provenientes do Jardim Zoobotânico de Franca, 2019.

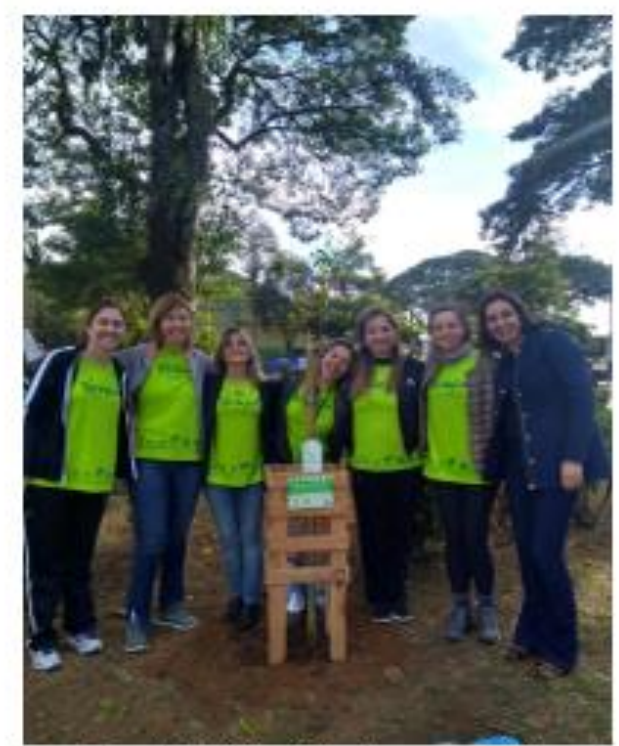

Fonte 5 - Verdejar Franca, 2019.

\section{CONSIDERAÇÕES FINAIS}

O Programa Educacional de Difusão do Pau-Brasil provou ser possível criar um circuito completo envolvendo as questões ambientais e a sociedade civil. Inclusive, sua longevidade só pode ser percebida se analisarmos como diversos setores da sociedade se incluíram no projeto e tornaram possível a realização do cultivo e plantio de mudas, além das oficinas e palestras visando a formação dos agentes envolvidos. Portanto, trata-se de um programa amplo e com atuação em todos os segmentos ambientais.

Em primeiro lugar, pois após sua criação, o Jardim Zoobotânico de Franca está munido de um Banco de Germoplasma do Pau-Brasil "Ex-situ", o que permite a tiragem de sementes para a produção de mudas em larga escala. Em segundo lugar, pois envolveu todas as escolas municipais e os agentes escolares em uma agenda de formação educacional e atividade prática de plantio das mudas. Em terceiro lugar, pois alcançou níveis distintos de instituições educacionais, tendo estabelecido relações também com as universidades do município. E, por fim, atingiu a máxima capilaridade ao transferir suas propostas também para as praças, o que permitia à população em geral ter acesso não só às oficinas e palestras, como também ao método de plantio e cultivo da espécie.

Assim, portanto, mostrou-se um programa sustentável, diverso e responsável, que rompeu barreiras nos programas de educação ambiental e inseriu a compreensão da relevância do Pau-Brasil em sua totalidade. Mais do que isso, 
reposicionou a relação do poder público com a sociedade no que tange às questões ambientais, visto que o ciclo ensino-aprendizado foi preenchido do início ao fim visando evidenciar a importância do Pau-Brasil, isto é, partindo desde o contato e da troca de sementes para a constituição do Banco de Germoplasma, até as oficinas e palestras, passando pelo cultivo e plantio com escolas, universidades e outros Municípios.

Todavia, é importante salientar que o programa foi exitoso pois envolveu em torno de um mesmo objetivo a pluralidade de segmentos sociais. Além da Prefeitura, através do Jardim Zoobotânico de Franca, houve participação da Universidade Federal Rural de Pernambuco, através da Estação Ecológica do Tapacurá (EET), do Instituto de Botânica de São Paulo, do IBAMA (Regional de Ribeirão Preto) e grande participação da iniciativa privada, sobretudo por meio da Autovias, Tribo dos Pés, Macboot e CCBEU.

\section{REFERÊNCIAS}

AGUIAR, Francismar Francisco Alves et al. Germinação de sementes e formação de mudas de Caesalpinia echinata Lam. (Pau-Brasil): efeito de sombreamento. Revista Árvore, [s.I.], v. 29, n. 6, p.871-875, dez. 2005. FapUNIFESP (SciELO). http://dx.doi.org/10.1590/s0100-67622005000600005.

ANDRADE. B.; MAURO, F; AXELSON, E.; BOXER, C. R.; SERRÃO, J. \& KELLENBENZ, H. Balanço da colonização portuguesa. Lisboa: Iniciativas Editoriais, 1975.

BERTELLI, Célio. Relatório do Programa Educacional de Difusão do Pau-Brasil. Prefeitura Municipal de Franca, 2005.

CARVALHO, P. E. Espécies arbóreas brasileiras. Brasília: Embrapa Informações Tecnológicas, 2003. p. 719-725.

Certificado Mérito ao Programa Educacional de Difusão do Pau-Brasil, Internacional Bridge Tunnel and Turnpike Association - IBTTA - 2006 Toll Excellence Awards.

FONTES, R. S. Pau-brasil, um sonho de resgate. Recife-PE. Editora Graftorre, p. 85-97, 1995.

GIL, Antônio Carlos. Como elaborar projetos de pesquisa. 4 ed. - São Paulo: Atlas, 2002.

LORENZI, H. Árvores brasileiras - manual de identificação e cultivo de plantas arbóreas nativas do Brasil. Nova Odessa, p. 145, Editora Plantarum, 1992.

Pau-Brasil ganha novo nome científico, de 13 de 2016. Disponível em: <http://oglobo.globo.com/sociedade/ciencia/pau-brasil-ganha-novo-nome-cientifico-

20282129>. Acesso em: 26 de julho de 2019.

População no último censo: IBGE, Censo Demográfico 2010.

PRADO JUNIOR, Caio. História Econômica do Brasil. 26. ed. São Paulo: Editora Brasiliense, 2012.

Prêmio 4ํㅡㄹ Benchmarketing Ambiental Brasileiro, Mais Projetos Corporativos. 
Prêmio Ambiental 'Von Martius', Edição 2005, AHK Câmara Brasil-Alemanha.

ROCHA, Yuri Tavares. Ibirapitanga: História, Distribuição Geográfica E Conservação Do Pau-Brasil (Caesalpinia echinata lam., leguminosae) do Descobrimento à Atualidade. 2004. Tese (Doutorado) - Curso de Geografia, Departamento de Geografia, Universidade de São Paulo (usp), São Paulo, 2004.

SÉGUIN, E.; CARRERA, F. Lei de crimes ambientais. Rio de Janeiro: Ed. Esplanada, 1999.

SOUZA, O. M. F. Pau-brasil: esse ilustre desconhecido. Recife: Universidade Federal Rural de Pernambuco, 1984. 


\section{ÍNDICE}

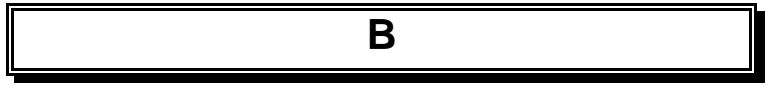

BATISTA, Gyovanna Alves, 32

BERTELLI, Célio, 19, 30, 82, 92

BOVO, Lúcia R. T, 42

BRITO, Erilze Maria da Silva, 82

\section{C}

CÂMARA, Naiá Sadi, 56

CAMARGO, Regina Aparecida Leite de, 71

CAMPAGNOLI, Eduardo Silva, 71

CARVALHO NETO, Silvio, 56

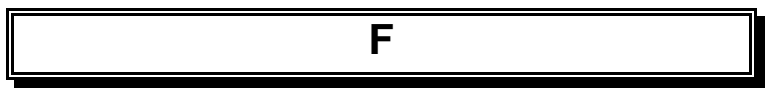

FALEIROS, Tâmer de Oliveira, 19, 30

FERREIRA, Marina, 32

FONSECA, Genaro Alvarenga, 8

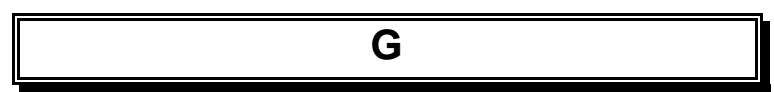

GONÇALVES, Débora, 71

GUIMARÃES, Orlinéya M., 42

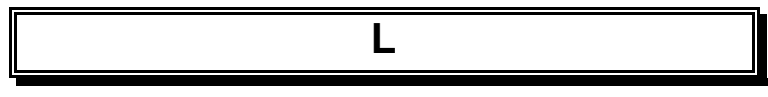

LEAL, Andréia Cristina de Britto, 56 LOPES, Matheus Fernandes A, 19, 82

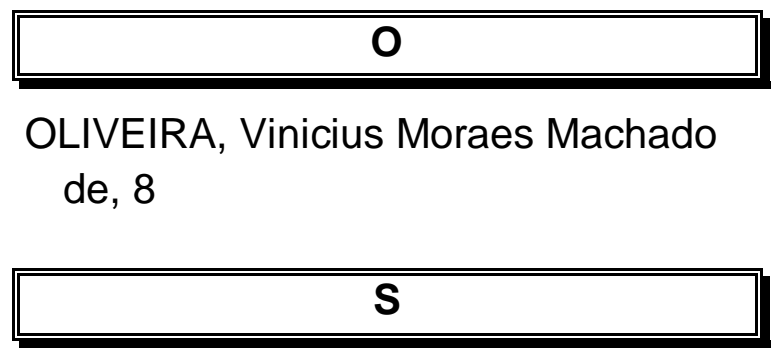

SOUZA, Tatiana Noronha de, 32

T

TAMBASCO, Aline de Oliveira, 8 


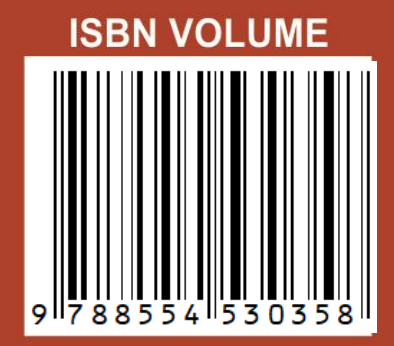

ISBN COLEÇÃO

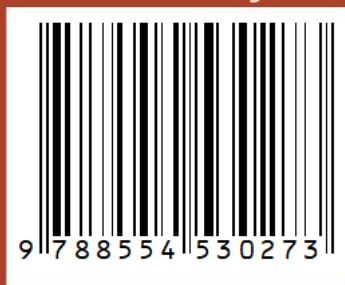

08009404688 | 163713.4688

unifacef.com.br | f 0 ๑ $\ominus$ y

163706.8700

franca.unesp.br 